\title{
ABSTRACT \\ ASSESSING THE ENVIRONMENTAL IMPACTS OF A BEACH NOURISHMENT OPERATION, MORRO BAY, CA
}

Dredging is carried out worldwide to maintain navigable water channels and to source sediments for beach nourishment operations. As sea level continues to rise throughout the $21^{\text {st }}$ century, dredging for beach nourishment is poised to become increasingly prevalent, and increasingly important in California, where as much as $86 \%$ of the coast is erosional. In repurposing dredge to nourish beaches, the impact of placing dredge material at a dumpsite (e.g., a beach or nearshore zone) is not well understood, as most studies on the impact of dredging focus only on the dredge pit from which material is excavated. To help understand impacts of using dredge material to nourish beaches, we use the recent 2016-2017 dredging operation in Morro Bay, CA, which placed between $3.9 \times 10^{5}$ to $7.6 \times 10^{5}$ cubic meters of sediment onto the nearby beaches. During the operation, the dredged sediments appeared to be significantly darker than the in-situ beach sand, leaving questions about ecosystem and sediment impacts to the original beaches. Spatial-temporal analyses of grainsize, mineralogy, biota, and stratigraphy were used to assess the impacts of the dredging event to the dumpsite and surrounding area. Grainsize results indicated that the dredge material was a unique facies with a median grainsize smaller than anything else observed in the study area. Mineralogy results supported the grainsize results in showing that the dredge material was a unique facies with a different percent abundance of quartz, intermediates, and lithics to the in-situ beach sand. Biology results suggested a correlation between finer sediments and increased biodiversity and organic matter. Stratigraphy results indicated that the dredge material remained buried at the dumpsite as a distinct facies for approximately one year before becoming visually undetectable. Applying the principle of the Littoral Cutoff 
Diameter (LCD), we posit that approximately one third of the dredge material was naturally deposited offshore while the remaining either remained at the dumpsite or was dispersed throughout the study area. Despite the initial sediment incompatibility introduced by the dredging, these findings lead to the conclusion that the dredge event had no discernible negative long-term impacts on the study area.

Cameron Alfving

August 2019 



\title{
ASSESSING THE ENVIRONMENTAL IMPACTS OF A BEACH NOURISHMENT OPERATION, MORRO BAY, CA
}

by

Cameron James Alfving

\author{
A thesis \\ submitted in partial \\ fulfillment of the requirements for the degree of \\ Master of Science in Geology \\ in the College of Science and Mathematics \\ California State University, Fresno
}

August 2019 


\section{APPROVED \\ For the Department of Earth and Environmental Sciences:}

We, the undersigned, certify that the thesis of the following student meets the required standards of scholarship, format, and style of the university and the student's graduate degree program for the awarding of the master's degree.

\section{Cameron James Alfving}

\section{Thesis Author}

Beth Weinman (Chair)

Earth and Environmental Sciences

Mara Brady

Earth and Environmental Sciences

Mathieu Richaud

Earth and Environmental Sciences

For the University Graduate Committee:

Dean, Division of Graduate Studies 


\section{AUTHORIZATION FOR REPRODUCTION}

\section{OF MASTER'S THESIS}

$\mathrm{X} \quad$ I grant permission for the reproduction of this thesis in part or in its entirety without further authorization from me, on the condition that the person or agency requesting reproduction absorbs the cost and provides proper acknowledgment of authorship.

Permission to reproduce this thesis in part or in its entirety must be obtained from me.

Signature of thesis author: 


\section{ACKNOWLEDGMENTS}

I would first like to acknowledge the endless support my wife, Alexa Alfving, has provided to me over the last five years as I progressed from community college through the M.S. program. Without her, this thesis would not exist. I would also like to thank my family for their encouragement and support. I owe a lot to my friends — old and newwho helped me stay positive when things were hard. My advisor, Dr. Weinman, has helped me become the scientist I hoped I would become when I began this program and challenged me to go beyond my comfort zone. The rest of the faculty have helped me in numerous ways - there is not space here to thank them all individually. Suffice it to say that I have learned much during my time in the Geology M.S. program and am thankful for everything I've been taught. 


\section{TABLE OF CONTENTS}

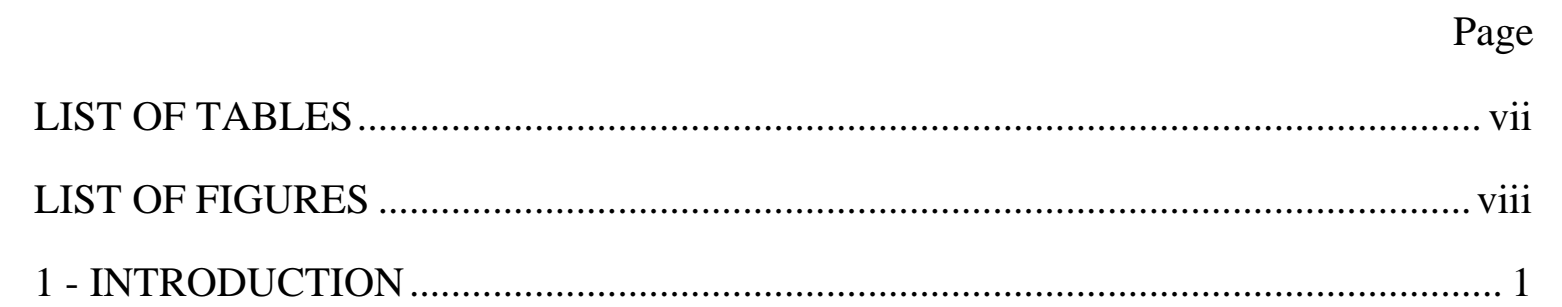

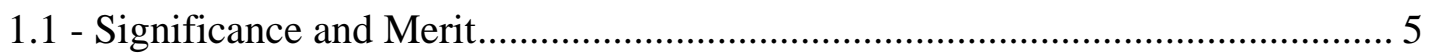

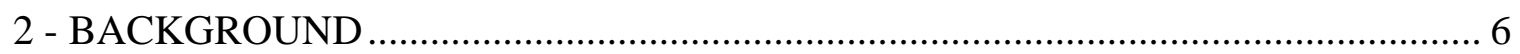

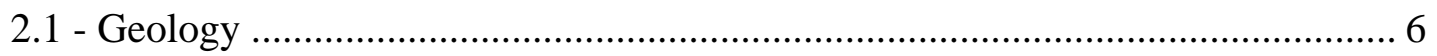

2.2 - Engineering ............................................................................................... 7

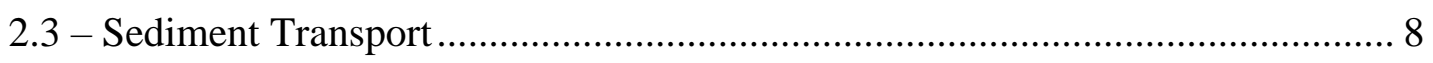

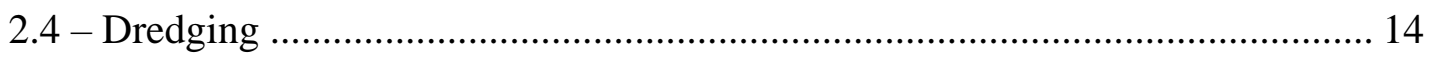

2.5 - Current Understanding of Dredge Impacts ...................................................... 15

2.6 - Gaps in Knowledge .................................................................................. 17

3 - OBJECTIVE AND HYPOTHESES ................................................................... 20

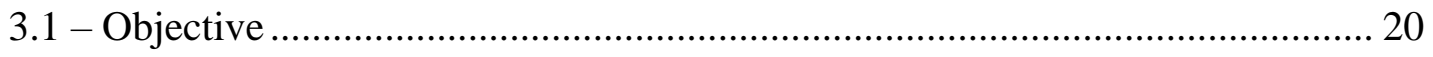

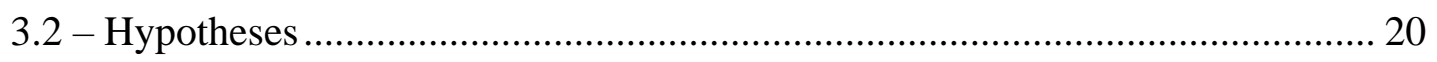

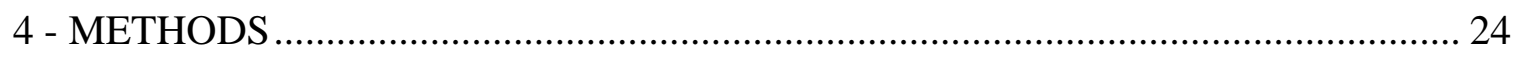

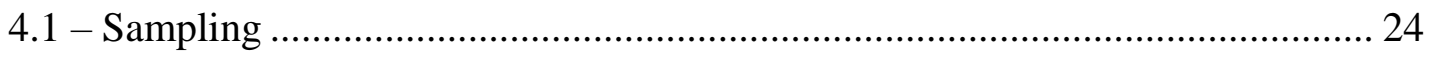

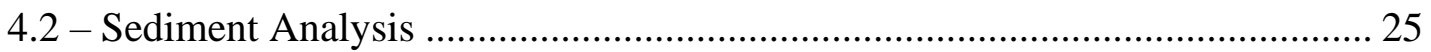

4.3 - Mineralogy and Loss on Ignition (LOI) ......................................................... 28

4.4 - Stratigraphic Columns ........................................................................... 29

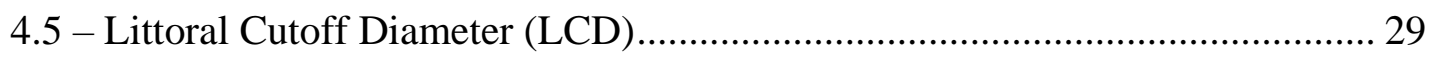

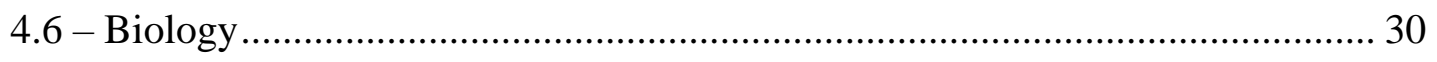

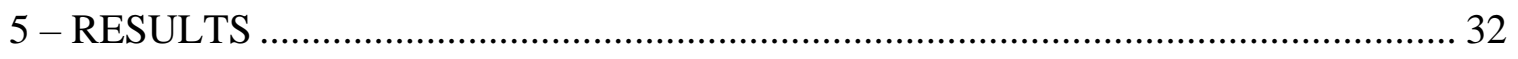

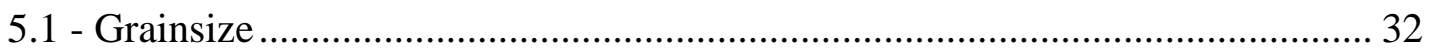




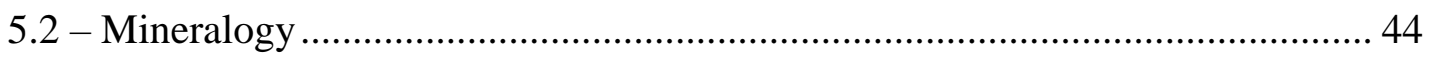

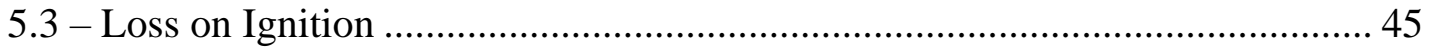

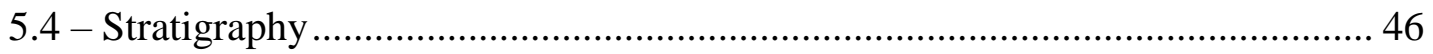

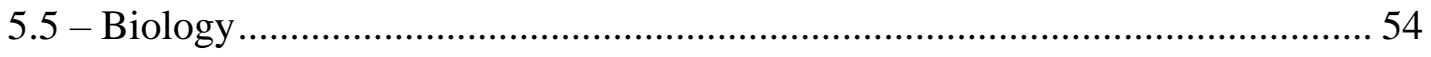

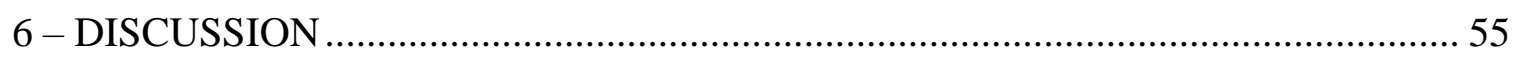

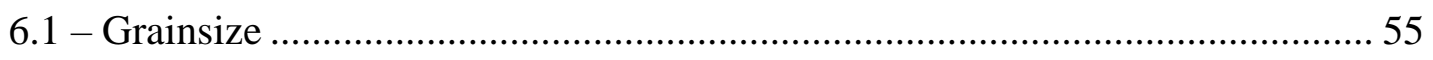

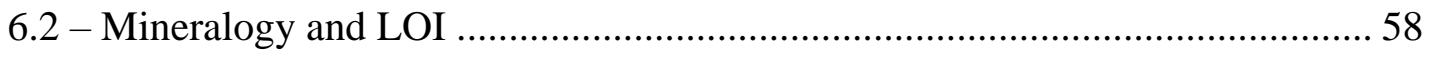

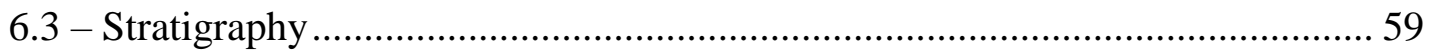

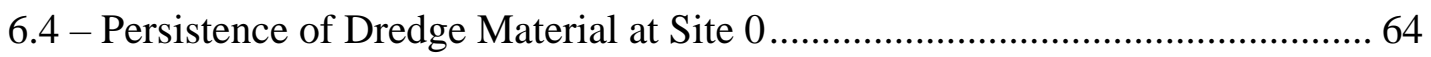

6.5 - Differences Between the Northern and Southern Beaches .......................... 65

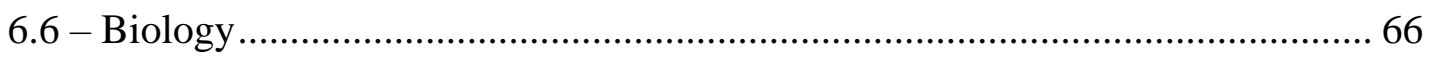

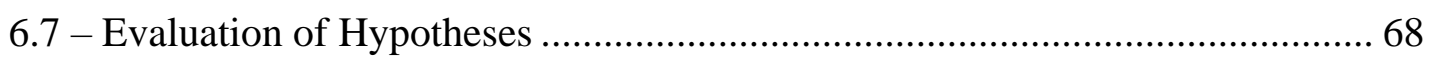

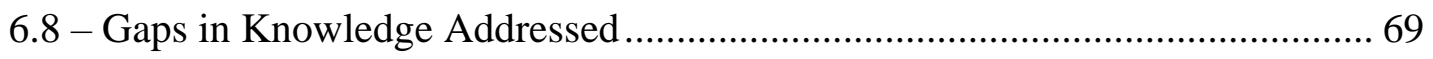

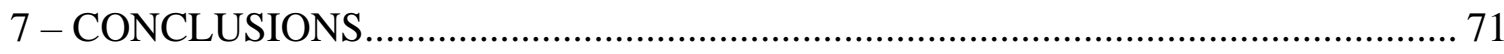

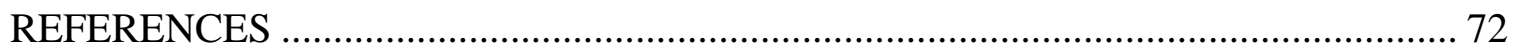

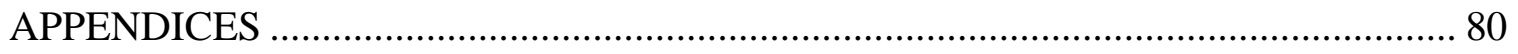

APPENDIX A: LITTORAL CELL TERRESTRIAL SEDIMENT SOURCES .............. 81

APPENDIX B: RANGE OF GRAINSIZES AVAILABLE TO LOCAL CREEKS ........ 83

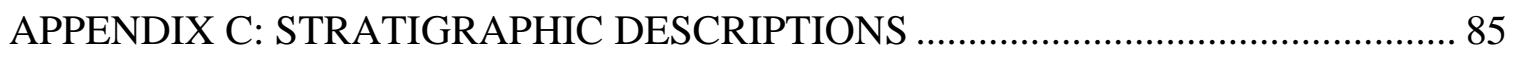

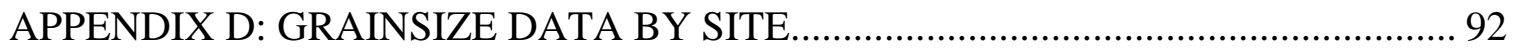

APPENDIX E: BIRD AND INVERTEBRATE SPECIES LISTS …......................... 95

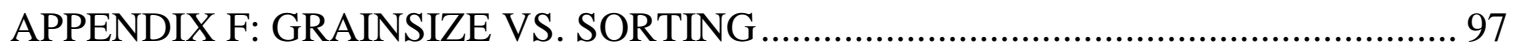

APPENDIX G: SURFACE SAMPLE MUNSELL COLORS .................................. 99 


\section{LIST OF TABLES}

Page

Table 1A: Material Parameters used on the Malvern Mastersizer 3000............................ 27

Table 1B: Standard deviations averaged from triplicate runs of 10 samples ................... 27

Table 2: Site 0 LCD values by month and overall ......................................................... 30 


\section{LIST OF FIGURES}

Page

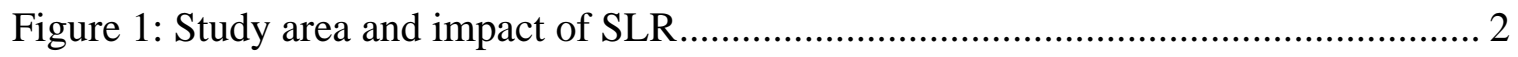

Figure 2: Dredged material vs. in-situ beach sand, Morro Strand State Beach, CA.. ....... 4

Figure 3: Engineering points of interest in Morro Bay, CA ...................................... 9

Figure 4: Sediment transport processes in Morro Bay, CA........................................ 11

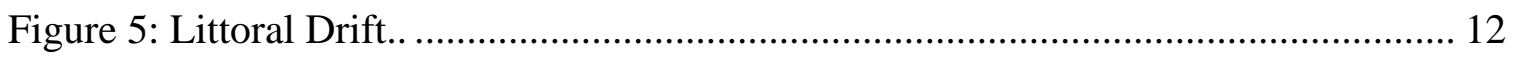

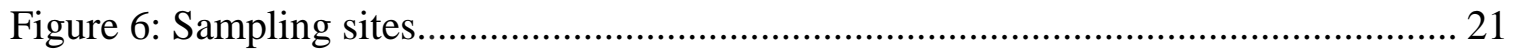

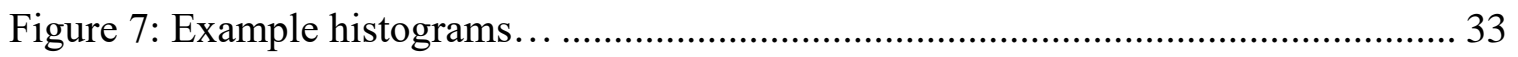

Figure 8: Cumulative frequency plot of the Harbor Sample vs. the Dark Stratum .......... 34

Figure 9: Temporal-spatial distribution of median grain size ..................................... 35

Figure 10: Box and whisker plots of temporal-spatial median grainsize........................ 37

Figure 11: Temporal-spatial distribution of median grain size.................................. 41

Figure 12: Temporal-spatial distribution of median grain size for all samples.............. 44

Figure 13: Percent abundance of quartz, intermediate, and lithic grains........................ 45

Figure 14: Percent loss-on-ignition (LOI) results................................................ 47

Figure 15: Stacking Patterns I and II (a), III and IV (b), and V and VI (c)................... 50

Figure 16: Stacking patterns by site location, over the entire year.............................. 51

Figure 17: Percent abundance of stacking patterns................................................ 53

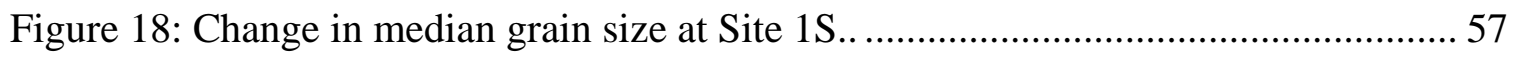

Figure 19: Cumulative frequency plot in Figure 9 with the LCD shown at $150 \mu \mathrm{m} . \ldots . . .63$

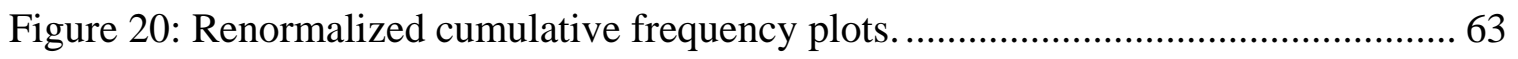

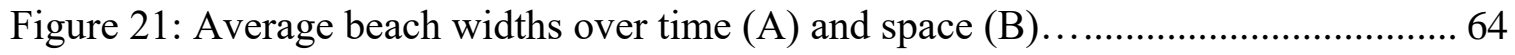

Figure 22: Mean bird species count (a) and mean invert species count (b) by site........ 67 


\section{1 - INTRODUCTION}

Worldwide, beach environments are highly regarded for their beauty, biodiversity, ecologic productivity, and importance as hubs for commerce and recreation (MBNEP, 2017; Spencer et al., 2016; Hopskin, 2012; Vorosmarty et al., 2009; Inman \& Frautschy, 1966). However, many of the world's beaches are expected to be impacted by erosion as sea level rises during the 21st century (Hinkel et al., 2013; Nairn et al., 2004). Hinkel et al. (2013) predict that without mitigation measures, 1.6 to 5.3 million people will be displaced from the world's coastlines during this century. An effective means of mitigating beach erosion has been through beach nourishment operations, which add sediment obtained from elsewhere (often through dredging) to eroding coastlines (Bishop et al., 2006; Work et al., 2004; Dean, 1988; Healy, 1994). While Hinkel et al. (2013) predict that beach nourishment will be the most effective method of fighting beach erosion in the 21st century, others caution that introducing large volumes of sediment to an area over a short period of time may qualify as pollution (Mearns et al., 2017). The scope of our current understanding of the impacts of using dredge spoil as beach nourishment material is limited (Peterson \& Bishop, 2005). Most studies focus on the borrow site of dredging operations rather than the dumpsite (Mearns et al. 2017; De Jonge et al., 2014; Nairn et al., 2004). The need to address this gap in our knowledge is especially prevalent in California, where as much as eighty-six percent of the coast is erosional (Moore et al., 1999; Dolan et al., 1985) and where several dredging operations have been conducted during the last 50 years (Griggs, 1987; Orme, 2005; Diaz Yourman, 2014). A recent beach nourishment operation in the small coastal community of Morro Bay, California (Figure 1) provides an excellent opportunity to develop our understanding of possible impacts from dumping material onto beaches for nourishment. 


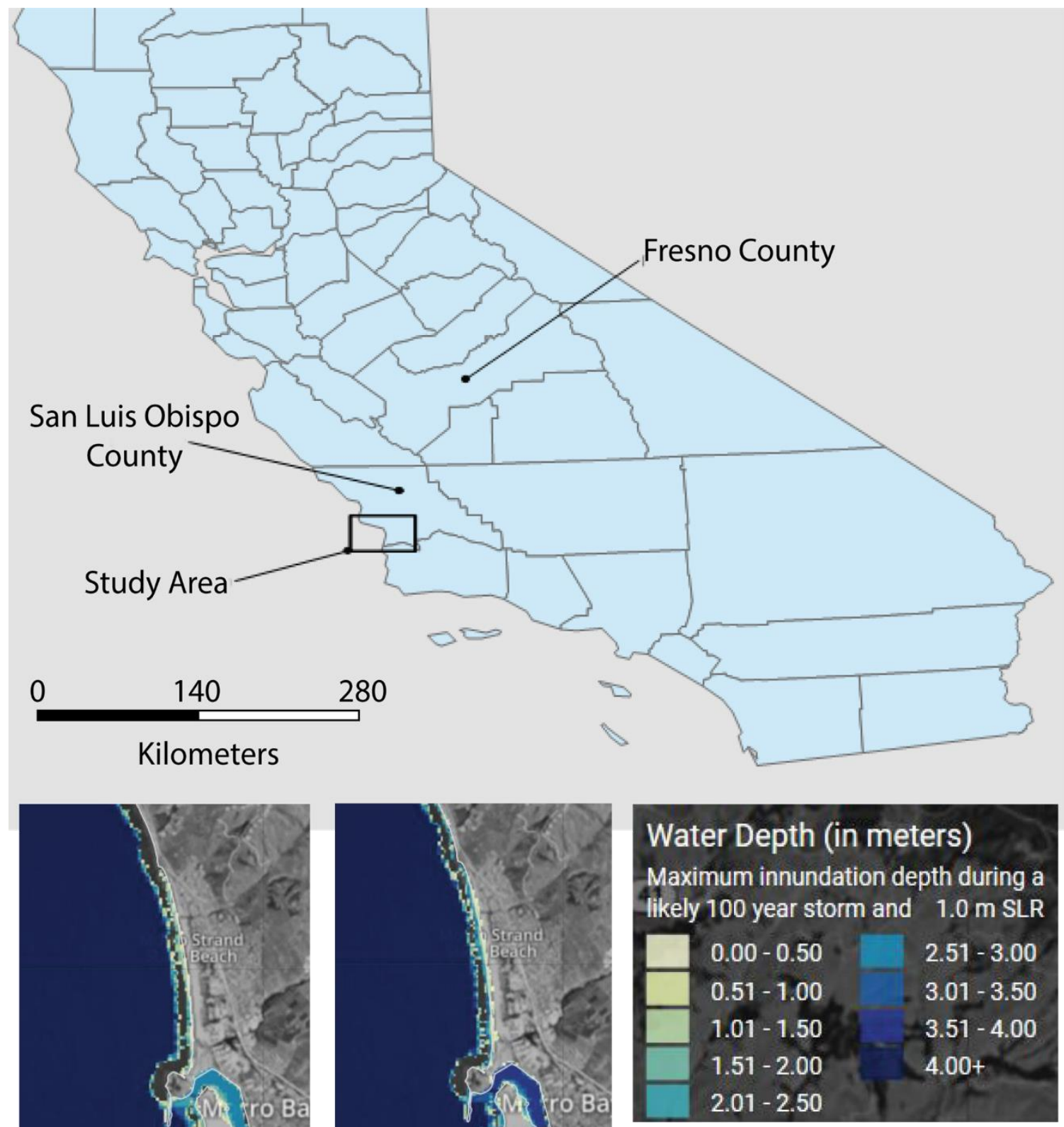

Figure 1: Top panel contains map showing the location of the Morro Bay study along the coast of California (data.ca.gov, UTM NAD 1983, Zone 10N). The left are two aerial images of the study area with sealevel inundation flooding heights from CalAdapt.org. The darker the color, the more the flooding height, with current and 1 meter sea level rise projections showing the vulnerability of this particular coastline. Overall, Nature Conservancy estimates $\sim 60 \%$ statewide beach loss with CA's Climate Assessment (2019) quoting \$50 million dollar annual economic impacts to protect coastal communities. 
In 1936, a causeway (i.e., an artificial land bridge) was built to connect the island landmark of Morro Rock to the California coastline, making Morro Bay the only geographically protected harbor between San Francisco and Los Angeles (USACE, 2016). The construction of the causeway, along with two breakwaters a few years later, interfered with the natural sediment transport processes in the area. This interference increased the amount of sedimentation in Morro Bay to the point that approximately $8.8 \mathrm{x}$ $10^{4}$ cubic meters of sediment have been deposited annually in the Bay since dredging began in 1949 (Orme, 2005; USACE, 2016).

Dredging is a process by which sediments are removed from the bottom of a body of water to increase depth and is necessary globally to maintain navigable channels (Pringle, 1996; Guerra, 2009). Dredging is also used as a means to source material for beach nourishment operations (Bishop et al., 2006; Work et al., 2004; Dean, 1988; Healy, 1994). In Morro Bay, dredging is required to maintain the United States Coast Guard's access to their Morro Bay station. It is also crucial to the economy of the eponymous town, which lines the eastern shore of the Bay and relies heavily on ecotourism and fishing for income (Chamber of Commerce, 2017).

In Morro Bay, minor maintenance dredging operations occur approximately once per year and dump approximately $1.0 \times 10^{5}$ cubic meters of sediment in the nearshore (shallow ocean) environment near a sand spit which forms the western shore of Morro Bay (USACE, 2016). Major dredging events in Morro Bay occur approximately once per decade and remove between $3.9 \times 10^{5}$ to $7.6 \times 10^{5}$ cubic meters of sediment over the course of several months. Historically, these sediments have been dumped in the intertidal zone at a site approximately 2 kilometers north of Morro Bay as part of an ongoing beach nourishment project (USACE, 2016). This location served as the dumpsite for the recent 2017 major dredging operation that is the focus of this study. While the dredged sediment was being dumped at the dumpsite, it was observed to have a distinct 
diesel odor and significantly darker hue compared to the in-situ beach sand (Figure 2).

This observation prompted a closer examination of the stratigraphic, sedimentologic, and biologic impacts of dumping dredge material at the dumpsite.

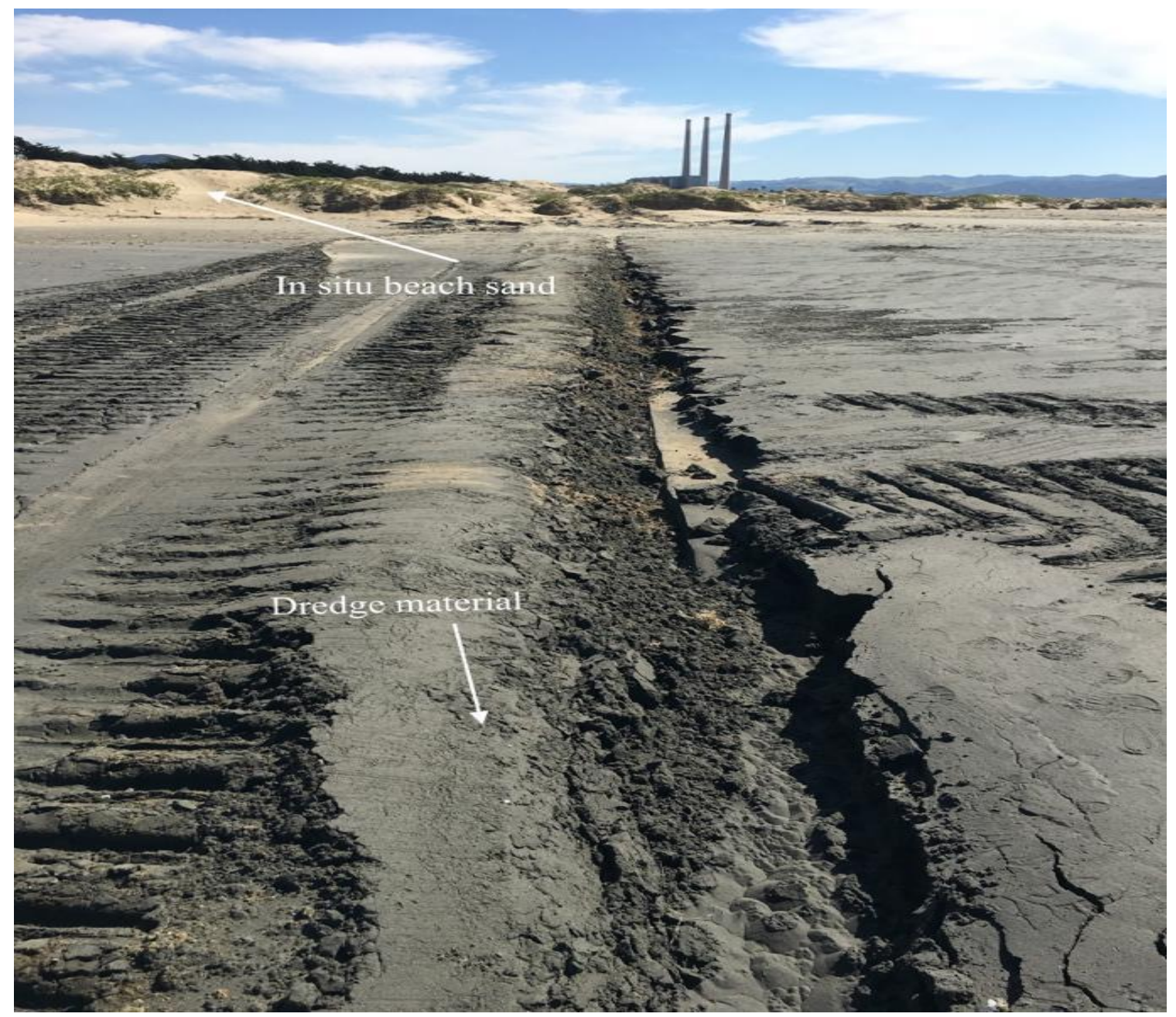

Figure 2: Dredged material vs. in-situ beach sand, Morro Strand State Beach, California. The dredge sands are noticeably darker and more reducing-looking than the more oxidized-looking native beach sands. Munsell colors of the sands were good depicters of the native beach vs. dredge differences: 10YR6/3 and 7.5 YR5/1, respectively.

Prior to the dredging operation that was carried out in 2017, the United States Army Corps of Engineers (USACE) published an Environmental Assessment (EA) concluding that the dumping of dredged sediment at Morro Strand State Beach would have no environmental impact in the area (USACE, 2016). A sedimentological study 
carried out by a USACE contractor as part of the EA found that the grainsize of the dredged sediments was similar to that of the beach sand at the dumpsite (Diaz Yourman, 2014). This project aims to take the next step in understanding the long-term effects of dumping the dredged sediments at Morro Strand State Beach, CA. Our findings will compliment concurrent research on bird and invertebrate populations conducted by Dr. Joshua Reece (Biology Department, Fresno State) with the goal of furthering our understanding of correlations between grainsize and biodiversity. The combination of all results will allow us to assess correlations between sedimentology, stratigraphy, and biodiversity in the context of a beach nourishment operation.

\section{1 - Significance and Merit}

This study will address a gap in our knowledge of the impacts of dredging to an onshore dumpsite by providing a comprehensive spatial-temporal analysis of several variables. The results of this study will help elucidate anthropogenic impacts on sedimentation and stratigraphy in coastal environments. It will also help show any linkages that exist between the sediments and the ecology (via collaborative work by Dr. Joshua Reece). The results of this study will help to determine whether additional considerations (e.g., biologic protections, stratigraphic analyses) are needed prior to dredging operations, which are conducted around the world. 


\section{2 - BACKGROUND}

\section{$2.1-$ Geology}

Morro Bay is located near the center of the much larger Estero Bay on California's central coast (Figure 1). While today the bay provides an active ocean community with a harbor, estuary, visiting landsite, recreation, and fishing (MBEDR, 2017), the region is built on a geologic underpinning of ridges and basins that formed as sedimentary, volcanic, and meta-sedimentary rocks were folded and faulted when the Pacific Plate began colliding with the North American Plate approximately 30 mya (Orme, 2005; Liu \& Furlong, 1992). In the last 1 my, the ridges were uplifted while the basins subsided (Orme, 2005), greatly influencing the topography of the coastline along the Central Coast (Orme, 2005). The ridges, part of California's Coastal Range, have formed resistant cliffs that do not allow for the formation of beaches (Orme, 2005; Hapke et al., 2008). These cliffs often front marine terraces cut by the ocean during the last interglacial $\sim 125$ kya (Orme, 2005). Alternatively, the basins have formed relatively wide, sandy beaches that strike NW-SE (Orme, 2005).

Several rock types are present in the Morro Bay region. Cliff-dominated shores are typically composed of siliceous shales (Moody \& Graham, 1995). In some areas, beaches are flanked by outcrops of the Franciscan mélange, which continues ESE to form most of the Coastal Range north of Morro Bay (Hsu, 1969). Some of the most striking features of the area are large, isolated exposures of igneous rock several hundreds of meters tall. These prominent formations are the dacite necks of extinct Oligocene volcanoes (Orme, 2005). The landmark of Morro Rock is the first of several volcanic necks that extend southeastward through the Los Osos Valley (Orme, 2005; Ford, 1997). The beaches in the area, which attract more than 1,400,000 visitors per year (Draft Marketing and Sales Plan, 2016) consist of Quaternary and Late Pleistocene sands 
(Orme, 2005). Quaternary sands are found in the intertidal zone of the beaches, while late Pleistocene sands form dunes further inland (Cousineau, 2012).

The Quaternary sands found in the region were sourced within coastal watersheds and delivered to the shore via a network of streams and rivers (Orme, 2005). The Los Osos Creek and Chorro Creek are the most important inland systems for delivering sediment to Morro Bay (Orme, 2005), though most of the sediments delivered by these creeks are deposited in an extensive salt marsh along the southern shore of Morro Bay well before they reach Morro Bay Harbor (Gallagher, 1996). The carrying capacity of these creeks has been significantly reduced due to damming and diversion (Orme, 2005). Smaller creeks deliver sediment to the beaches north of Morro Bay (Orme, 2005).

While some sediments within the Bay are thought to be sourced from creekinputs, the sands along the shores of Morro Bay--as well as the majority of those within the Bay itself--are more likely from nearby off-shore and littoral origins. The beach north of the Bay's inlet directly connects to marine terrace and resistant cliff-forms, while the beach south of the inlet formed approximately 5 kya as an extensive sand spit extended northward to close off what is now Morro Bay Harbor from the Pacific Ocean (Orme, 2005). The sand spit today extends for approximately 6.5 kilometers along the western shore of the Harbor and is considered an active dune complex (Orme, 2005), and for the purposes of this study initially considered as a "control" area to compare with the beaches north of the Morro Bay inlet that served as the dredge dumping and beach replenishing area (Figure 2).

\section{2 - Engineering}

While Morro Bay has been modified by engineering projects, the area is recognized as one of the least-disturbed wetland systems along the central and southern coast (MBNEP, 2016). The most prominent engineering project was the causeway built 
to connect Morro Rock to the mainland (Figure 3). Completed in 1936, the causeway cut off an existing natural channel between Morro Rock and the mainland (Haggemann et al., 2000). During World War II, the United States Navy sought to modify the entrance to Morro Bay further (Orme, 2005; Haggemann et al., 2000). A northern breakwater (Figure 3) was built so that Navy patrol boats and planes could enter Morro Bay more easily (Orme, 2005; Haggemann et al., 2000). However, since the project was rushed (Orme, 2005) and sediment transport dynamics were poorly understood (Inman \& Frautschy, 1966), the construction of the northern breakwater amplified sedimentation in the entrance channel (Haggemann et al., 2000). A southern breakwater was subsequently built to combat the sedimentation issue, but the entrance and other channels have suffered from infilling of sediment ever since (Orme, 2005). Indeed, Orme (2005) argues that the creation of the breakwaters actually created a "sediment trap" by increasing the natural effect of Morro Rock on reversing the longshore current direction along the coast.

\section{$\underline{2.3-\text { Sediment Transport }}$}

Sediment transport dynamics within the Morro Bay system occur within the context of the equilibrium beach profile, which can be thought of as the profile a beach would assume if all of the forces acting upon it (e.g., gravity, waves, wind) were in balance (Dean \& Charles, 1994). The different forces acting upon a given beach are always changing; therefore, all beaches (and the sediments within their profile) are in a constant state of flux as they evolve toward the equilibrium beach profile that would best balance those forces (Dean \& Charles, 1994; Woodroffe, 2002). There are three important mechanisms that allow sediment to move within the beach system as it changes toward equilibrium: 1) seasonal equilibrium profiles, 2) littoral drift, and 3) eolian transport (Figure 4; Bruun, 1954; Devoy et al., 1996; Patsch \& Griggs, 2005). Understanding these mechanisms provides context not only for the sedimentation 


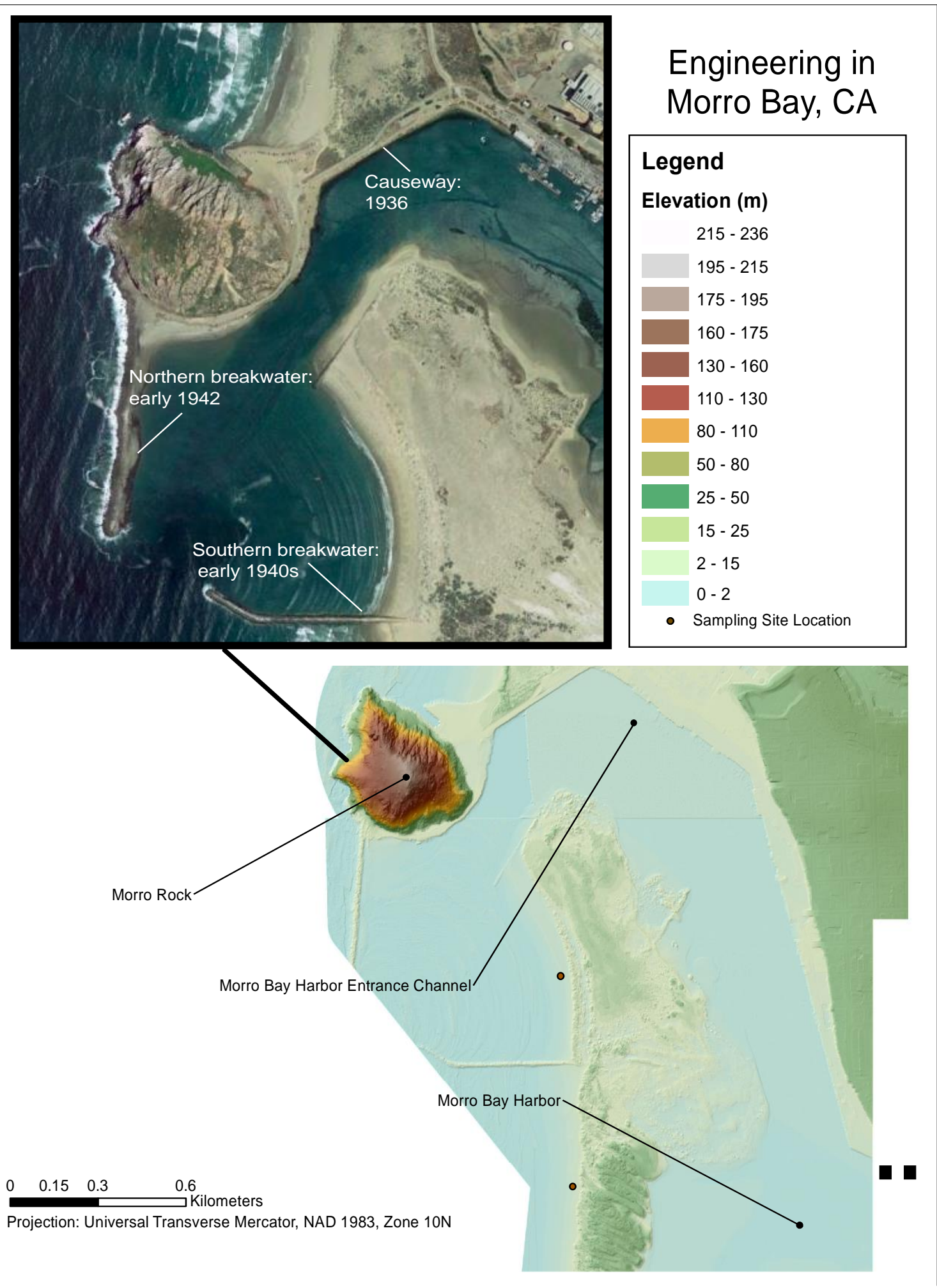

Figure 3: Engineering points of interest in Morro Bay, CA. The map shows the location of the Entrance Channel and Harbor. The inset photograph (note buildings for scale) shows the years in which major engineering projects were completed: the causeway was constructed in 1936; the northern breakwater was completed in 1942, with the southern breakwater following soon after. 
problems that have plagued Morro Bay for decades, but for the temporal-spatial changes observed across the study area as well.

\subsection{1 - Seasonal On-Offshore Transport}

Seasonal changes in beach profiles are well-understood. Bruun (1954) noted that shorelines generally prograde during the summer and retrograde in the winter, producing wider and narrower beaches, respectively. The driving factor behind seasonal equilibrium profiles is wave energy (Dean, 1991; Yates et al., 2009a): beaches evolve toward a new equilibrium profile as wave energy decreases (increases) in summer (winter). In winter, stronger waves remove much of the finer sediments from the berm and transport them to an offshore bar, where they are essentially 'stored' until they are redeposited on the berm in summer. Barring strong storms, sediment is not lost from the overall beach profile in the transition between seasonal equilibrium profiles (Kraus, 2005) - the same cannot be said of the other two sediment transport mechanisms in the beach environment.

\subsection{2 - Littoral Drift}

Littoral drift refers to the nearshore movement of sediment via suspension in a longshore current (Inman \& Frautschy, 1966). Longshore currents form as waves break along a shoreline at an oblique angle (Figure 5 and Patsch \& Griggs, 2005). Littoral drift occurs within a specific boundary called a littoral cell (Inman \& Frautschy, 1966; Patsch \& Griggs, 2005), which can be defined as "a coastal segment that neither receives sediment from, nor contributes sediment to adjacent [segments]" (Inman \& Frautschy, 1966). This means that each littoral cell has its own source of sediment and its own sink for sediment to be deposited into (Patsch \& Griggs, 2005). It is important to note that while a single littoral cell will not receive sediment from other cells, the sources of sediment within the cell can be varied (Orme, 2005). Orme (2005) notes that the Morro Bay inlet area receives sediment from the Los Osos, Chorro, and Morro Creeks, with 


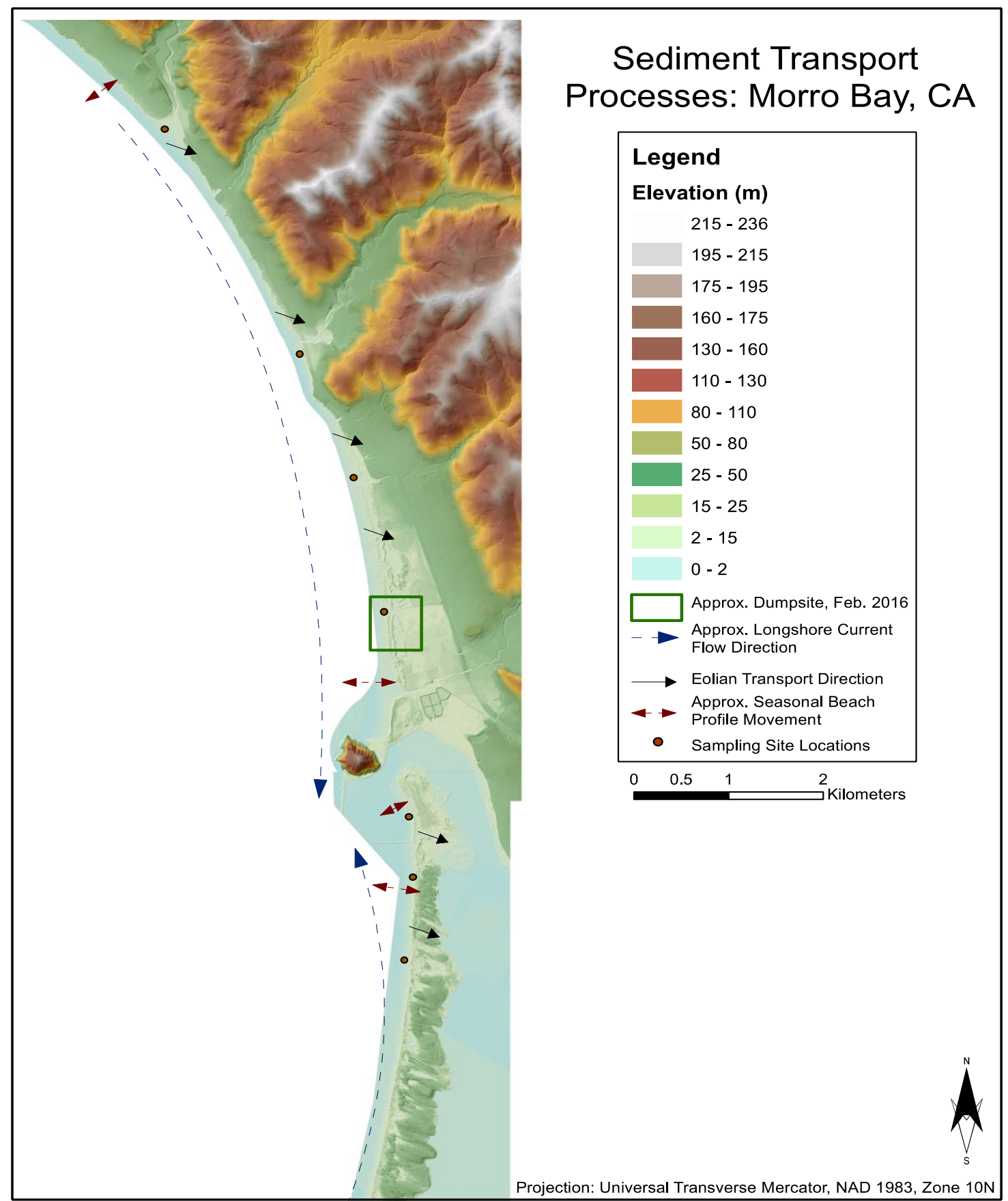

Figure 4: Sediment transport processes in Morro Bay, CA. The red dual arrows indicate the movement of sediment as part of the seasonal beach equilibrium profile cycle. Sediment is not lost from the beach in this process. The blue dashed arrows indicate littoral drift direction within the Morro Bay littoral cell. This is the predominant process removing sand from the beach in this area. The black arrows indicate the predominant direction of eolian transport- this process removes the finest sediments from the beach and deposits them into dune complexes throughout the area. 


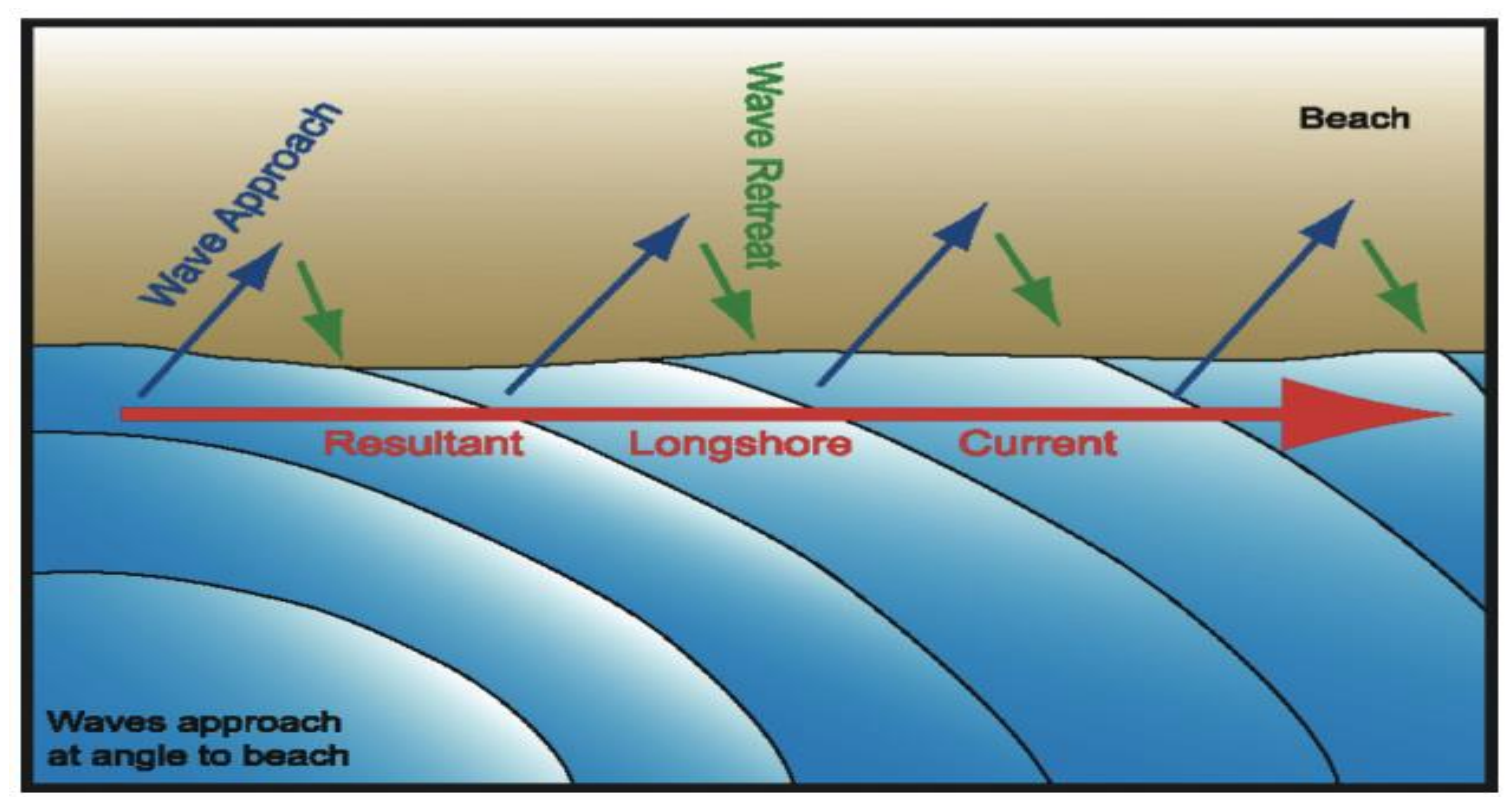

Figure 5: Littoral Drift. Waves break at an oblique angle to the shoreline and move landward during the 'swash' phase. Water returns to the ocean at a different angle during the 'backwash' phase. This creates a type of zigzag movement that transports sediment parallel to the shore face (from Patsch \& Griggs, 2005).

2014 flow assessment reports indicating that northern (Willow and Toro Creeks) and southern (Islay and Coon Creeks) creeks also deliver sediment to the littoral zone (see Appendices A and B).

California is divided into twenty-five littoral cells (Patsch \& Griggs, 2005). The majority of these host a net-southward littoral drift (Inman \& Frautschy, 1966; Patsch \& Griggs, 2005). The Morro Bay littoral cell, however, consists of longshore currents that converge at Morro Rock (USACE, 1973; Dingler et al., 1982; Patsch \& Griggs, 2005; Orme, 2005; USACE, 2016). North of Morro Rock, the net littoral drift flows southward like it does along most of California's coast and transports as much as $1.3 \times 10^{4}$ cubic meters of sediment annually (Orme, 2005). South of Morro Rock, the net littoral drift flows northward due to the impact of summer storms that approach the coast from the south (Orme, 2005; USACE, 2016) and transports as much as $2.4 \times 10^{4}$ cubic meters of sediment annually (Orme, 2005). This characteristic is one reason why Morro Bay has 
had historic problems with sedimentation: the littoral drift currents converge at the mouth of the Bay (i.e., the entrance channel) and cause the area to act as a sink for the sediments (Griggs, 1987; Orme, 2005).

The finest available sediments on a beach will not be entrained by the littoral drift mechanism. The Littoral Cutoff Diameter (LCD) is defined by Hicks (1985) as a grainsize threshold below which sediment will not remain on a given beach in any significant quantity. The LCD has received much attention as a tool for calculating sediment budgets for littoral cells in California (Hicks, 1985; Best \& Griggs, 1991; Eittreim et al., 2002; Runyan \& Griggs, 2003; Limber et al., 2008). In this study, the LCD can be used to understand how much dredge material would have been removed from the littoral drift mechanism and deposited offshore (see Sections 4.5 and 6.3.1). It is unclear what percentage of fine material is lost offshore due to the LCD versus deposited in dune complexes as a result of eolian transport. This is due in part to the difficulty in quantifying the amount, let alone size, of sediments entrained by eolian processes (Davidson-Arnott, 2005).

\section{$\underline{\text { 2.3.3 - Eolian Transport }}$}

Eolian transport occurs as fine grained sediments, such as fine to very fine sands, silts, and clays, are transported overland by wind (Prothero \& Schwab, 2014). This process is an important dynamic in many beach environments as it allows the finest available sediments to form dune complexes at the landward edge of a beach (Kroon \& Hoekstra, 1990). Characteristic dune complexes are present north and south of Morro Rock, but the most extensive active complex in the area lies to the south on the sand spit that acts as the western shore of Morro Bay (Orme, 2005; Cousineau, 2012). Along the sand spit, the active dune complex is part of the sink that defines the Morro Bay littoral cell (Orme, 2005). Fine and very fine sands are carried southeastward by the prevailing 
northwest winds (Orme, 2005). This further contributes to the sedimentation problem within Morro Bay as these sands are eventually blown back into the Bay (Orme, 2005). The convergence of two littoral drift currents at the mouth of Morro Bay and the presence of a natural sink in the form of an active dune complex along its western shore highlight why Morro Bay has undergone dredging operations for more than half a century (Haggemann et al., 2000; Orme, 2005; USACE, 2016).

\section{$\underline{2.4-\text { Dredging }}$}

Dredging has been used to maintain navigable waterways for decades (van Maren et al., 2015). It has also been used as a means of obtaining material for beach nourishment operations (Hinkel et al., 2013). Without it, many important harbors and shipping lanes around the world would be unusable (Smith \& Rule, 2001). The dredging process itself is invasive and disruptive to the environment owing to several hundreds of thousands of cubic meters of benthic sediment removed during a single dredging operation (USACE, 2016). The process is known to increase turbidity and disrupt the insitu marine life; however, these immediate impacts are observed only over a short time period, and typically only at the site where dredge sediments are sourced (De Jonge et al., 2014). The longer-term impacts at the site where the dredge is received (i.e., dumpsite) remain poorly understood and are of greater concern to environmental groups, coastal and riparian communities, and scientists (Healy, 1994).

The long-term impacts of dredging are born from two distinct aspects of the operation: the dredge pit and the dumpsite. The dredge pit is the location from which sediment is removed, while the dumpsite is where sediment is placed. The long-term impacts of each are difficult to gauge due to the number of variables involved (Demir et al., 2004). However, most research into the impacts of dredging has focused on the dredge pit (Mearn et al. 2017; van Maren et al., 2015; De Jonge et al., 2014; Nairn et al., 
2004; Work et al., 2004). Of the studies that have been conducted on the impacts of dredging at dumpsites, most focus on offshore or nearshore dumpsites (Du Four \& Van Lancker, 2008; Weinberg \& Hebbeln, 2005). Fewer still have focused on sedimentological and stratigraphical impacts, choosing instead to assess impacts to biota (Bishop et al., 2006; Smith \& Rule, 2001; Peterson et al., 2000). Indeed, Peterson \& Bishop (2005) note that the state of research on the impacts of dumping sand onto dumpsites (i.e., beach nourishment) leaves much to be desired. In their overview of beach nourishment studies during the last 40 years, Peterson \& Bishop (2005) state that the methods, interpretations, and conclusions of several studies were flawed, in large part due to the fact that the majority --59\%-- were conducted in a non-peer-reviewed setting by government agencies or private firms. It is apparent that there is much left to be learned about the impacts of beach nourishment operations; therefore, it is necessary to review the peer-reviewed literature to understand where the gaps in our knowledge lie.

\section{5 - Current Understanding of Dredge Impacts}

Studies that have examined the geologic impacts of dumping dredged sediments at a given dumpsite have primarily focused on changes in geomorphology (Du Four \& Van Lancker, 2008; Yates et al., 2009b; Weinberg \& Hebbeln, 2005). In regard to geomorphology, there is a consensus that dumpsites return to their pre-dredge morphology within one or two years. This timeframe appears to be true of dumpsites located both in the nearshore (Du Four \& Van Lancker, 2008; Weinberg \& Hebbeln, 2005) and onshore zones (Yates et al., 2009b). Researchers unanimously credit the dynamism of natural currents for the rapid mitigation of any initial changes to the geomorphology of the dumpsites in their study areas.

The sedimentologic and stratigraphic impacts of dumping dredged sediments onto a dumpsite are significantly less understood. In high-energy, offshore environments, 
dredge material appears to be naturally removed too quickly to have a discernible impact on the sedimentology (e.g., mean grainsize) or stratigraphy of a dumpsite (Du Four \& Van Lancker, 2008). However, impacts to these parameters become more apparent in lower-energy environments, or in cases where the sedimentology of the dredge material is significantly different to that of the in-situ material—what Parkinson \& Ogurcak (2018) refer to as "sand compatibility." To minimize possible deleterious impacts to native sediment biota (i.e., burrowing and sediment-feeding invertebrates), dredge material should have a similar texture, composition, and color to the in-situ beach sand (Parkinson \& Ogurcak, 2018).

Du Four \& Van Lanker (2008) noted differences in mean grainsize and stratigraphy at an offshore dumpsite located in a low-energy, tidal gully environment. They noted that the in-situ sand was interbedded with mud and clay strata that were introduced during a dredging operation. These strata remained unchanged throughout the year-long period in which they were observed. Pezzuto et al. (2004) also noted a significant change in the sedimentology at the dumpsite in their study area, but they did not assess changes in stratigraphy. The dumpsite observed was located onshore, with varying wave energy from strongest (weakest) in the north (south). The dredge material that was dumped was approximately $25 \%$ silt and clay by weight, whereas the in-situ material at the dumpsite was almost exclusively fine to very fine sand. The authors noted that after the dredge material was dumped, the dumpsite became coarser grained overall, with the average composition of fine to very fine sand being replaced by medium sand. Similarly to Du Four \& Van Lanker (2008), Pezzuto et al. (2004) saw this change persist during the entirety of the year-long period in which the dumpsite was observed, suggesting that sedimentological impacts to dumpsites may be longer-term than geomorphological ones. If using dredge as nourishment can more permanently alter a 
beach, what this means in terms of native infauna impacts can become a concern—along with affects to species at other trophic levels.

To date, there is limited data on dredge-impacted correlations between biota and grainsize. Among dredge-impact studies that examined impacts to biota (Bishop et al., 2006; Smith \& Rule, 2001; Peterson et al., 2000), the data show only low-resolution correlations. Bishop et al. (2006) noted that new assemblages of macroinvertebrates replaced existing assemblages as grainsizes at an offshore dumpsite became coarser postdredge. Smith \& Rule (2001) noted no discernible impact on macroinvertebrate populations due to the dredged sediments having similar physical characteristics to the insitu beach sand. Peterson et al. (2000) reported decreases in macroinvertebrate populations in connection to dredge material that was finer than the in-situ beach sand at two onshore dumpsites.

Limited data on straightforward grainsize-biota correlations does exist (Jaramillo et al., 1993; MacMillan et al., 2017). Jaramillo et al. (1993) studied macroinvertebrate populations on ten beaches along the Chilean coast and found that coarser grained sands were correlated with fewer invertebrate species. MacMillan et al. (2017) sampled macroinvertebrate populations on fourteen beaches along the eastern Canadian coast and, contradictory to Jaramillo et al.'s (1993) findings, found no correlation between grainsize and population.

\section{6- Gaps in Knowledge}

There are several gaps in our knowledge of how dumpsites are impacted by dredge material. This project seeks to provide a comprehensive examination of some key variables that can impact a dumpsite, which is currently absent from the literature. Impacts to the geomorphology of dumpsites from dumping dredge material are currently the best understood. However, there are limitations to our comprehension even here. The 
majority of studies that looked at geomorphological impacts focused on subaqueous, nearshore dumpsites (i.e., Du Four \& Van Lancker, 2008; Weinberg \& Hebbeln, 2005). Of these impact studies, only one (Du Four \& Van Lanker, 2008) looked at parameters outside of those relating directly to geomorphology. Weinberg \& Hebbeln (2004) and Yates et al. (2009b) looked only at topographic/bathymetric data. It is important to note that the latter two studies concluded that there were negligible impacts to the dumpsite after a period of one year, but Du Four \& Van Lanker (2004), who looked at sedimentologic data in addition to bathymetric data, observed changes persisting for a longer timeframe.

Our understanding of impacts to the sedimentology and stratigraphy of dumpsites is also limited by a lack of sufficient spatial-temporal analysis (Peterson \& Bishop, 2005). Du Four \& Van Lancker (2004) succeed in this regard, but Pezzuto et al. (2004) only provide a spatial analysis. Their sampling scheme covered a large, representative area, but they only took sediment samples during a two-month period. If we are to understand how sedimentology and stratigraphy are impacted by dredge material, a higher resolution evaluation of changes over space and time is needed.

In terms of coupling biology with geology, previous research that correlates grainsize to biota lacks overall consensus. Studies by Bishop et al. (2006), Smith \& Rule (2001), and Peterson et al. (2000) concluded that macroinvertebrate populations were impacted by coarser grains, not impacted at all when grains were similar in size to in-situ beach sand, and impacted by finer grains, respectively. In regard to the impacted macroinvertebrate populations, it is unclear if the change in grainsize or the dredge event itself was the primary impactor. The limited data from Jaramillo et al. (1993) and MacMillan et al. (2017) that exists on grainsize-biota correlation is contradictory. Furthermore, both of these studies conducted sampling over a short time frame (over the course of one day and two weeks, respectively). Leber (1982) and Brazeiro \& Defeo 
(1996) showed that a year-long sampling scheme is needed to reflect changes in macroinvertebrate populations through seasonal changes in the beach environment. Data from an extended sampling period is therefore required to resolve whether or not there is a correlation between grainsize and biologic populations.

Upon reviewing the literature on the impacts of dumping dredge material onto dumpsites, it is clear that three questions remain unanswered: (a) the actual impact of dumping dredged material onto dumpsites is unclear due to a lack of comprehensive research that takes several variables (e.g., grainsize, stratigraphy) into account; (b) there is a need for more research that looks at temporal and spatial changes in sedimentology and stratigraphy; (c) there is a need for research that captures seasonal changes in biologic populations as they relate to grainsize changes post-dredge. Doing so will elucidate whether the impacts to biota observed in previous studies are related more directly to changes in grainsize or to the introduction of dredge material to the environment. 


\section{3 - OBJECTIVE AND HYPOTHESES}

\section{$\underline{3.1-\text { Objective }}$}

This project seeks to provide a comprehensive spatial-temporal assessment of the impacts of dumping dredged material onto an onshore dumpsite. Our goal is threefold:

first, we aim to understand how sedimentologic and stratigraphic variables may correlate to either: a) change important characteristics of the beach environment, causing measurable impacts, or b) mitigate any potential impacts, leaving the study area relatively unchanged. Second, we aim to assess these impacts at a higher-resolution spatialtemporal scale than currently exists in the literature. Finally, we aim to compare biodiversity to grainsize to understand how introducing new material to an environment may affect coastal bird and invertebrate species.

\section{2- Hypotheses}

Null Hypothesis: Dumping dredged sediment at the dumpsite will not interfere with the natural sedimentology, stratigraphy, and biology of the area.

The dredged material will have no discernible impact on the study area. The United States Army Core of Engineers (USACE) (2016) concluded that similarities in grainsize and absence of harmful chemical contaminants would preclude the dredged sediments from having any negative impact on the dumpsite or surrounding area (Figure 6). If Hypotheses 1A, 1B, and 1C are false, then this hypothesis can reasonably be accepted as viable.

Hypothesis 1: Dumping the dredged sediment at the dumpsite will interfere with the natural sedimentology, stratigraphy, and biology of the area.

Hypothesis 1A: The dredged sediments will be sedimentologically different from the sand at Morro Strand State Beach and Montaña De Oro State Beach. This hypothesis predicts grainsize and mineralogical properties among the dredged sediments that 


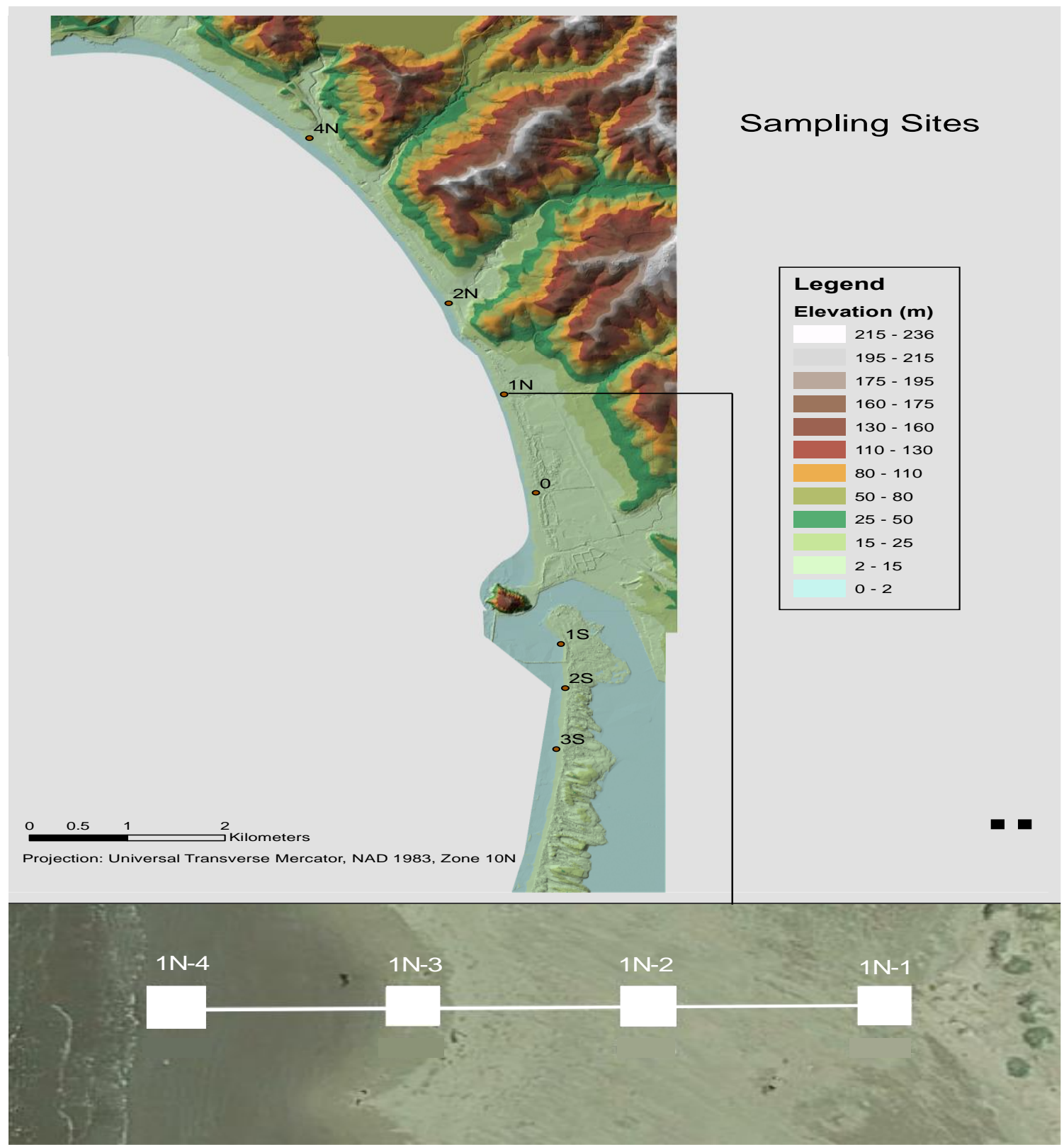

Figure 6: Sampling sites. Site 0 marks the dumpsite where dredge spoil was placed during the 2016 USACE dredging operation. Insert: Example of transect layouts throughout the study area. The '1N' designation denotes the transect's location within the study area. The ' $1 \mathrm{~N}-1$ ' designation indicates that a sample was taken at the duneward-most section of the $1 \mathrm{~N}$ transect. Transect shown extends approximately $60 \mathrm{~m}$. 
differentiate them from the in-situ beach sand throughout the study area. These differences should be visible in at least three ways. First, since the vast majority of the material in Morro Bay Harbor was deposited via littoral drift and eolian transport (Dingler et al., 1982), one would expect a larger percentage of fine sediments compared to the in-situ beach sand in the study area (since coarser material will remain on the beach). Second, one would expect a higher percentage of heavier, denser minerals among the dredged sediments compared to the in-situ beach sand since Morro Bay Harbor acts as a sink for sediments (Orme, 2005). Third, the dredged sediments should have a higher concentration of organic material, since a diverse ecosystem (e.g., eel grass, invertebrates, vertebrates) thrives in the calm waters of Morro Bay Harbor.

Hypothesis 1B: There will be an abrupt change in stratigraphy at the dumpsite, indicating a significant change in the depositional environment. The dumping of sediment onto Morro Strand State Beach could reasonably be likened to a storm or flood deposit. As such, one could expect the dredged sediments to be observable as a distinct stratum at the dumpsite. If observed, such a stratum could suggest that shoaling (Fruergaard et al., 2013) and burial of benthic organisms (Bishop et al., 2006) is occurring due to the dumping of the dredged sediment.

Hypothesis 1C: The dredged sediments will remain localized at the dumpsite, indicating that changes to the environment are happening in a relatively small area. Dingler et al. (1982) proposed that the littoral drift currents in Estero Bay converge at the mouth of Morro Bay Harbor. It therefore appears unlikely that littoral drift will disperse the dredged material throughout the field area. Orme (2005) noted that winds in the area predominantly blow from the northwest, transporting the finest available sediments to the southeast. North of the Harbor, where the dumpsite is located, these currents would transport sediments toward the bay or trap them locally in the dunes that line Morro Strand State Beach. It seems unlikely that eolian transport will disperse the sediments 
throughout the study area. Therefore, any of the impacts predicted by Hypotheses 1A and 1B should be localized at the dumpsite. 


\section{4 - METHODS}

\section{$\underline{4.1-\text { Sampling }}$}

The sampling scheme used in this study was designed to gather spatial-temporal data throughout the study area. Seven transects were established to ensure that the sampling covered the study area of interest, with transects spaced every $\sim 1-2 \mathrm{~km}$ over the $10 \mathrm{~km}$ shoreline (Figure 6). Each transect spanned approximately ENE to WSW from the dunes to the intertidal zone (Dingler et al., 1982; Barnard et al., 2013; USACE, 2016). Three transects were established both north and south of a central transect, which encompassed the 2017 dumpsite. Each transect was assigned an alphanumeric name that reflected its location in the field area (i.e., '0' for the dumpsite, $1 \mathrm{~N}$ for the first transect north of the dumpsite, $1 \mathrm{~S}$ for the first transect south of the dumpsite; see Figure 6). Each transect was further subdivided into quarters, with the first quarter being nearest the landward part of the beach, and the fourth quarter being nearest the oceanward section (Figure 6).

Beginning in July 2017, surficial sediment samples at each quarter point of every transect were gathered monthly over the course of one year. Using a small trowel, these samples were gathered from approximately the upper 3 centimeters of sediment for the purpose of analyzing spatial-temporal differences in grainsize throughout the study area (Hypothesis 1A). Altogether, twenty-eight surface samples were collected each month, resulting in 364 samples total for grainsize analysis to capture sediment changes throughout the year. For comparison, two samples - one dredge and one suspected dredge, were also measured. Samples representing the actual dredged sediments were measured from a diving expedition taken from the dredge pit in April 2018. A dark stratum layer observed during stratigraphic sampling which was suspected to be remnant dredge was also collected from Site 0, at $\sim 30 \mathrm{~cm}$ depth during November 2017's sampling 
(Appendix C). These samples were labeled as "Harbor" and "Dark Stratum," which relate to dredge and suspected dredge discussed in the findings.

The stratigraphy along each transect was analyzed seasonally over a year-long period. Stratigraphic pits were dug to a minimum depth of 30 centimeters in both the foreshore and backshore of each transect at low tide (i.e., at the ends of each transect). A total of 56 pits (14/season) were described in November 2017 (Fall), February 2018 (Winter), April 2018 (Spring), and July 2018 (Summer). While in the field, the stratigraphy within the pits was measured and described qualitatively by noting sedimentary structures and sediment characteristics (e.g., roundness, sorting) and quantitatively by estimating the percent abundance of quartz, intermediate minerals, and lithics. Measurements and descriptions were dictated by the appearance of distinct lithologic breaks within the stratigraphic pits. Field photos were also taken for later reference. Using a trowel, sediment samples were collected from the stratigraphic pits when individual strata were visually different from the surficial sediments. The results of the stratigraphic analyses were used to look for changes in stratigraphy (Hypothesis 1B) by providing data on how the stratigraphy of the dumpsite differed from the stratigraphy of the other sampling sites (Tamura et al., 2011). The data were also used to understand how dredge material was moving throughout the study area (Hypothesis 1C).

\section{$\underline{4.2-\text { Sediment Analysis }}$}

Surficial and stratigraphic samples were analyzed for grainsize with a Malvern Mastersizer 3000, using the dry attachment. This allowed for a shorter processing time compared to traditional sieving (Dingler et al., 1982; Barnard et al., 2013), as well as finer and more continuous grainsize resolution. Once sediment samples were brought to the Hydrology Lab at Fresno State, preparation consisted of drying the samples at $60^{\circ} \mathrm{C}$ for 24 hours in an Isotemp oven. After the samples were dried, their color was described 
using the Munsell characterization for soil color (GLOBE, 2012). Sand that was not clearly dark in color (7.5YR5/1, Figure 2) was interpreted to be in-situ beach sand (10YR6/3). The samples were then sieved with a $2 \mathrm{~mm}$ sieve, after which the $>2 \mathrm{~mm}$ and $<2 \mathrm{~mm}$ portions of each sample were weighed (most samples had no $>2 \mathrm{~mm}$ fractions $(\mathrm{n}=295), 20$ samples ranged from $0.1-2.5 \%>2 \mathrm{~mm}$ fraction, 10 samples had $2.5-10 \%$ $>2 \mathrm{~mm}$, 5 samples had 10-20\% >2mm, and 6 samples had 20-40\%>2mm). Sample portions $<2 \mathrm{~mm}$ were then used for Malvern analysis to ensure that no grains larger than $2 \mathrm{~mm}$ entered the machine. Using Software Version 3.62, a Standard Operating Procedure (SOP) was created for the dry attachment to ensure consistent measurements. The SOP assumed the material parameters outlined in Table 1A. The Malvern measured the grainsize parameters of each sample once, using the Fraunhofer scattering model, with final results obtained using the General Purpose analysis model. Grainsize results were reported to include the $>2 \mathrm{~mm}$ fraction, with accuracy and precision accounted for via instrument calibration and triplicate sample standard deviations. Accuracy was measured using triplicate analyses of Malvern standard QAS3002 with $\mathrm{D}_{10}=36.4$, D50 $=61.7, \mathrm{D}_{90}=90.4 \pm 0.1 \mu \mathrm{m}$ results. The precision (standard deviation) for the grainsize data was determined by selecting 10 samples to run three times (instead of the typical single run used for the majority of the samples, which is the instrument's default dry procedure). The standard deviation for each of these ten samples was calculated from the three 10th, 50th (median) and 90th percentile values obtained from the triplicate runs. These were then averaged to obtain a general precision of $\pm 2 \mu \mathrm{m}$ assumed for the rest of the sediment samples (Table 1B). 
Table 1A: Material Parameters used on the Malvern Mastersizer 3000

\begin{tabular}{|l|l|}
\hline Parameter & Value Used \\
\hline Particle Type & $\begin{array}{l}\text { Opaque } \\
\text { (Fraunhofer } \\
\text { Approximation) }\end{array}$ \\
\hline Material Name & SoilSand \\
\hline Refractive Index & 0 \\
\hline Particle Density & $1.05 \mathrm{~g} / \mathrm{cm}^{3}$ \\
\hline Absorption Index & 0 \\
\hline Air Pressure & $2 \mathrm{barg}$ \\
\hline Feed Rate & $25 \%$ \\
\hline
\end{tabular}

Table 1B: Standard deviations averaged from triplicate runs of 10 samples

\begin{tabular}{|l|l|l|l|}
\hline Sample & $\begin{array}{l}\text { Dx }(10) \\
(\mu \mathrm{m})\end{array}$ & $\begin{array}{l}\text { Dx (50) } \\
(\mu \mathrm{m})\end{array}$ & $\begin{array}{l}\mathrm{Dx} \\
(90) \\
(\mu \mathrm{m})\end{array}$ \\
\hline 2-18 3S-1 & 1.21 & 0.822 & 1.97 \\
\hline 2-18 3S-2 & 3.34 & 4.47 & 6.25 \\
\hline 2-18 3S-3 & 0.892 & 1.71 & 3.04 \\
\hline 2-18 3S-4 & 3.44 & 4.98 & 8.44 \\
\hline 2-18 2S-1 & 0.707 & 0.977 & 2.14 \\
\hline 2-18 2S-2 & 0.796 & 0.567 & 1.42 \\
\hline 2-18 2S-4 & 1.69 & 1.42 & 1.58 \\
\hline 2-18 1S-1 & 0.505 & 2.04 & 5.89 \\
\hline 2-18 1S-2 & 0.765 & 0.777 & 1.07 \\
\hline 2-18 1S-3 & 0.508 & 1.12 & 2.20 \\
\hline $\begin{array}{l}\text { Avg. Std. } \\
\text { Dev. }\end{array}$ & 1.39 & 1.89 & 3.40 \\
\hline
\end{tabular}




\section{3 - Mineralogy and Loss on Ignition (LOI)}

The mineralogy of the Harbor and Dark Stratum samples were analyzed to help clarify whether or not dredge material was found within beach stratigraphy (Hypothesis 1A). For each of these samples, a total of approximately 150 grains of sediment were randomly selected and analyzed under a Leica stereo microscope in groupings of 10-20 grains (Krumbein, 1952). Each grouping was photographed using the Leica Application Suite V4 (LAS V4.4). Using the high-quality photo, the grains were enumerated and grouped by apparent composition (i.e., quartz, intermediates, and lithics). The following classification scheme was used: clear, glassy grains were assumed to be quartz; dull, and/or vitreous light-colored grains were assumed to be intermediates; dull and/or vitreous dark/black grains were assumed to be lithics. When a minimum of 150 grains were counted (i.e., 8-15 photos) the total grains in each classification were used to quantify the percent abundance of quartz, intermediates, and lithics for a given sample. (i.e., QIL percent abundance; geogenic material; Krumbein, 1952). This method was used to provide a more quantitative QIL percent abundance than the traditional qualitative field estimation method. The QIL percent abundance data were used to determine whether or not the samples were the same facies.

As a proxy for organic and inorganic (shell) carbon content, a sequence of sediment combustion based on EPA Method 160.4: Residue, Volatile (Gravimetric, Ignition at 550 degree C) was followed using a Thermo Scientific Muffle Furnace 4000. Using sediment samples taken between July 2017 and February 2018, and soon following sampling and/or refrigeration, $\sim 20 \mathrm{~g}$ aliquot of sand from each sample was placed into beakers and put into a drying oven at 60 degrees $\mathrm{C}$ for 24 hours. Once dried, the samples were given a Munsell color designation and sieved through a $2 \mathrm{~mm}$ sieve (same as 4.2 above), after which a $\sim 5 \pm 0.5 \mathrm{~g}$ aliquot was added to ceramic crucible, re-dried in a drying oven for $24+$ hours to record dry weight and then combusted at $550^{\circ} \mathrm{C}$ for 4 hours 
for an organic-C weight indication. After being weighed, the samples were placed back into the oven for combustion at $1000^{\circ} \mathrm{C}$ for an inorganic- $\mathrm{C}$ weight indication. Once cool, the samples were weighed again, with organic and inorganic content being calculated by the following standard LOI formulas.

$$
\begin{gathered}
\left(\left(\mathrm{M}_{550}-\mathrm{M}_{\mathrm{dry}}\right) / \mathrm{M}_{\mathrm{dry}}\right) * 100=\% \text { Organic Lost } \\
\left(\left(\mathrm{M}_{1000}-\mathrm{M}_{550}\right) / \mathrm{M}_{550}\right) * 100=\% \text { Inorganic Lost }
\end{gathered}
$$

Triplicates run on July 2017 sands from site 2 S-4 produced results within $\pm 0.3 \%$ and $\pm 0.1 \%$ for organic and inorganic findings, respectively, with inorganic findings agreeing with the range of percent shells observed during Leica microscopy $(\sim 1 \%)$.

\section{$\underline{4.4-\text { Stratigraphic Columns }}$}

Stratigraphic data were used to make stratigraphic columns for comparing stratigraphy and dispersal of the dredge material across the study area. The fielddescribed measured sections were analyzed to identify common stacking patterns. The SedLog program (software version 3.1) was used to create digital stratigraphic columns of the six total stacking patterns identified from the stratigraphic columns (described in results). The abundance and spatial-temporal distribution of these stacking patterns were used to understand how stratigraphy changed throughout the field area during the course of the study.

\section{5 - Littoral Cutoff Diameter (LCD)}

Using Best \& Griggs' (1991) method, the LCD was calculated by finding the mean $10^{\text {th }}$ percentile $\left(D_{x} 10\right)$ grainsize value for a given month, along the percentile's standard deviations. Next, one standard deviation was subtracted from the mean $\mathrm{D}_{\mathrm{x}} 10$ value to calculate the LCD, representing the minimum grainsize capable of persisting at the dumpsite (Site 0), given the existing localized wind-water energy conditions. The LCDs for individual months are shown in Table 2, but the value used in the analysis was 
that for the overall mean $\mathrm{D}_{\mathrm{x}} 10$ value of $158 \mu \mathrm{m}$. This value was calculated by finding the mean of each month's transect location and averaging them. The standard deviation was calculated based off the overall mean values and then subtracted from the mean Dx10, leaving grainsizes below $150 \mu \mathrm{m}$ unstable at Site 0 .

Table 2: Site 0 LCD values by month and overall

\begin{tabular}{|l|c|c|c|c|c|c|c|c|c|c|c|c|c|c|}
\hline $\begin{array}{l}\text { Dx } 10-\text { Transect } \\
\text { Location }\end{array}$ & Jul & Aug & Sep & Oct & Nov & Dec & Jan & Feb & Mar & Apr & May & Jun & Jul & Avg. \\
\hline 01 & 169 & 155 & 173 & 151 & 157 & 158 & 163 & 154 & 148 & 149 & 149 & 182 & 163 & 159 \\
\hline 02 & 166 & 178 & 153 & 154 & 155 & 162 & 183 & 155 & 140 & 146 & 147 & 192 & 163 & 161 \\
\hline 03 & 161 & 172 & 156 & 155 & 148 & 161 & 155 & 145 & 141 & 150 & 162 & 182 & 159 & 157 \\
\hline 04 & 147 & 165 & 162 & 142 & 145 & 167 & 148 & 138 & 146 & 150 & 171 & 153 & 154 & 153 \\
\hline Mean Dx10 & 161 & 168 & 161 & 151 & 151 & 162 & 162 & 148 & 144 & 149 & 157 & 177 & 160 & 158 \\
\hline STDDEV & 10 & 10 & 9 & 6 & 6 & 4 & 15 & 8 & 4 & 2 & 11 & 17 & 4 & 8 \\
\hline LCD & 151 & 158 & 152 & 145 & 146 & 158 & 147 & 140 & 140 & 147 & 146 & 160 & 155 & $\mathbf{1 5 0}$ \\
\hline
\end{tabular}

\section{$\underline{4.6-\text { Biology }}$}

In tandem with the geological/sedimentological sampling, avian and invertebrate surveys were conducted by Dr. Joshua Reece and graduate student Shelby Moshier from Fresno State's Biology Department in order to see how sediment differences possibly impact beach ecology/biology. Avian surveys were conducted monthly at each transect and consisted of a five-minute, 360-degree sweep with binoculars to quantify the number of individuals of each species on the beach. Flying birds were not recorded unless the observers could ensure that individuals were not counted twice. Invertebrate surveys were conducted quarterly at each of the seven transects in November 2017, February 2018, April 2018 and July 2018. These surveys consisted of using an auger to take four sediment cores close together between high tide and low tide at each transect. The set of four cores were swirled with sea water and extruded through a $5 \mathrm{~mm}$ sieve to collect invertebrates within the sand. The process was repeated for a second set of four cores at a different location between high tide and low tide at the transect. The collected 
invertebrates were dyed and fixed in buffered formalin solution for identification. Identification was done in the Reece lab with results of the avian and invertebrate counting shared for comparison with the sedimentology and stratigraphy. 


\section{5 - RESULTS}

The results are presented following the order of the methods section, beginning with data trends found in each type of analysis: common grainsize facies and overall grainsize results, mineralogy, stratigraphic stacking patterns, and ending with the biology. Throughout each section, the temporal results are displayed first, followed by spatial results for the same parameters.

\section{$\underline{5.1 \text { - Grainsize }}$}

The vast majority of the beach sands (320 samples; $89 \%$ of all samples, Figure 7a) exhibited a normal bell curve, indicating a singular, well-sorted grainsize facies of $\sim 200 \mu \mathrm{m}$ at a given sample location. The remaining 11\% of the samples (39 samples) were bimodal, indicating two distinct grainsize facies. The majority of the grains in all bimodal samples were similar in size to the normal bell curve samples (Figure 7a \& b); a minority of grains in the bimodal samples were larger than the grains in the normal bell curve samples. The Harbor Sample (Figure 7c) was the only bimodal sample to show a second sediment facies smaller in size compared to the predominant facies (Figure 7a).

The April 2018 Harbor Sample, which was collected to represent the original dredge material, was significantly smaller than any other material found throughout the study area (Figure 7c), with a cumulative curve tailing quite different from the other beach sands more typically found throughout the area (Figure 8). The median grainsize of the dredge was $163 \mu \mathrm{m}$, while the next smallest median grainsize observed in the study area was $190 \mu \mathrm{m}$ (Site 4N-3 in November 2017), again showing the Harbor Sample as being distinctly smaller. As for the Dark Stratum, which was suspected to be a buried remnant dredge layer, the median grainsize was $211 \mu \mathrm{m}$, which is larger than the Harbor Sample, with its cumulative curve in Figure 8 showing a pattern distinct from the other 
sands, with a "steeper" curve, indicating the stratum is the most well-sorted, coarser than dredge, yet finer than the more typically found $\sim 200 \mu \mathrm{m}$ beach sands.

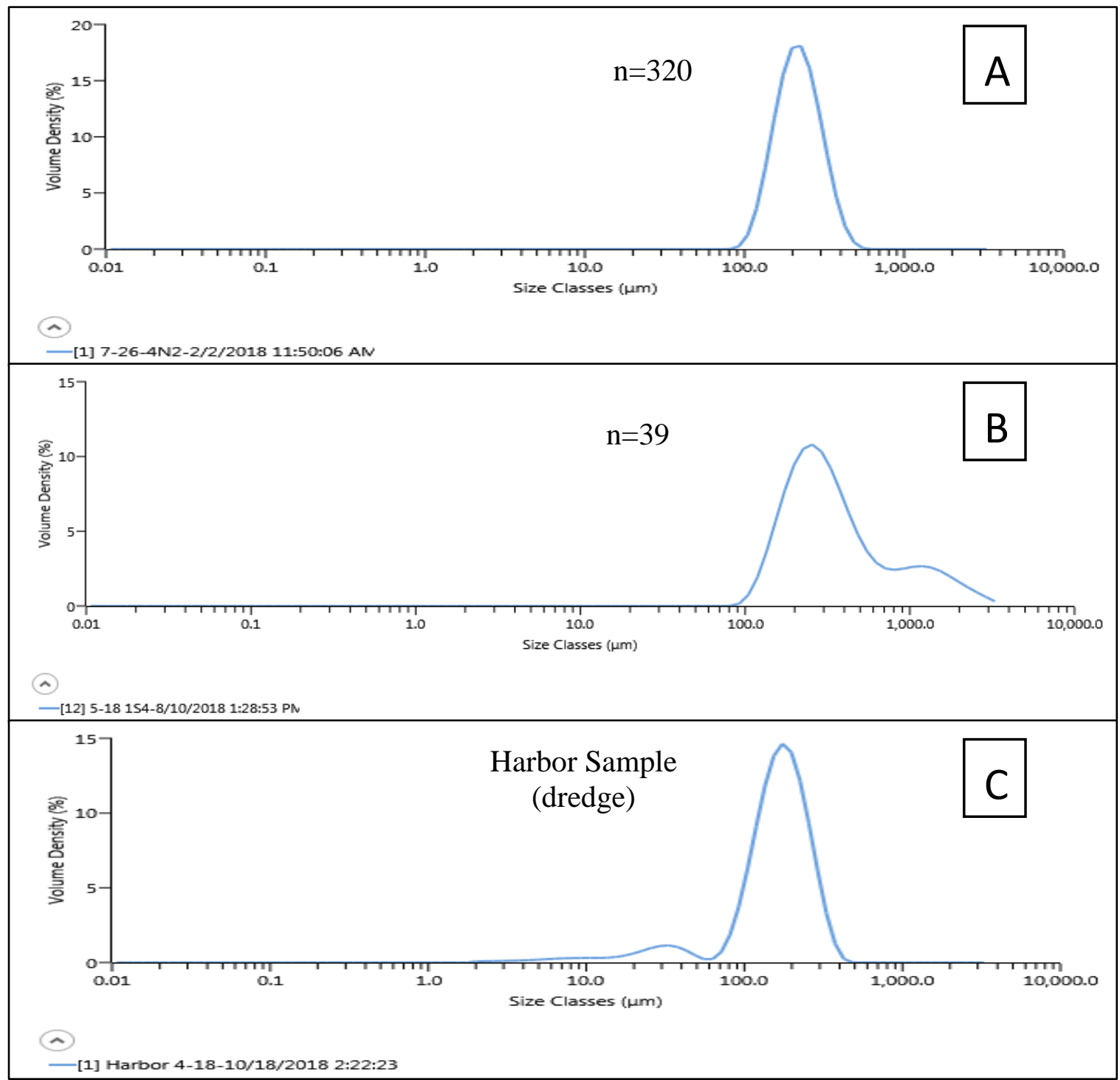

Figure 7: Example histograms representing the different grain size readouts from the Malvern. The y-axis shows volume density percent while the logarithmic x-axis shows grain size in microns. Fig. 7a is representative of the $n=320$ samples that exhibited a single mode-each of these samples exhibited a single grain size class falling between 100 and $1000 \mu \mathrm{m}$. Fig. $7 \mathrm{~b}$ is representative of the $\mathrm{n}=39$ samples that were bimodal with a coarser subcomponent - each of these sample types exhibited a majority of grains in the 100-1000 $\mu \mathrm{m}$ range with a second class slightly above the $1000 \mu \mathrm{m}$ mark. Fig. 7c shows the Harbor sample, which was the only bimodal sample to exhibit a secondary curve among grains smaller than those within the predominant curve. 


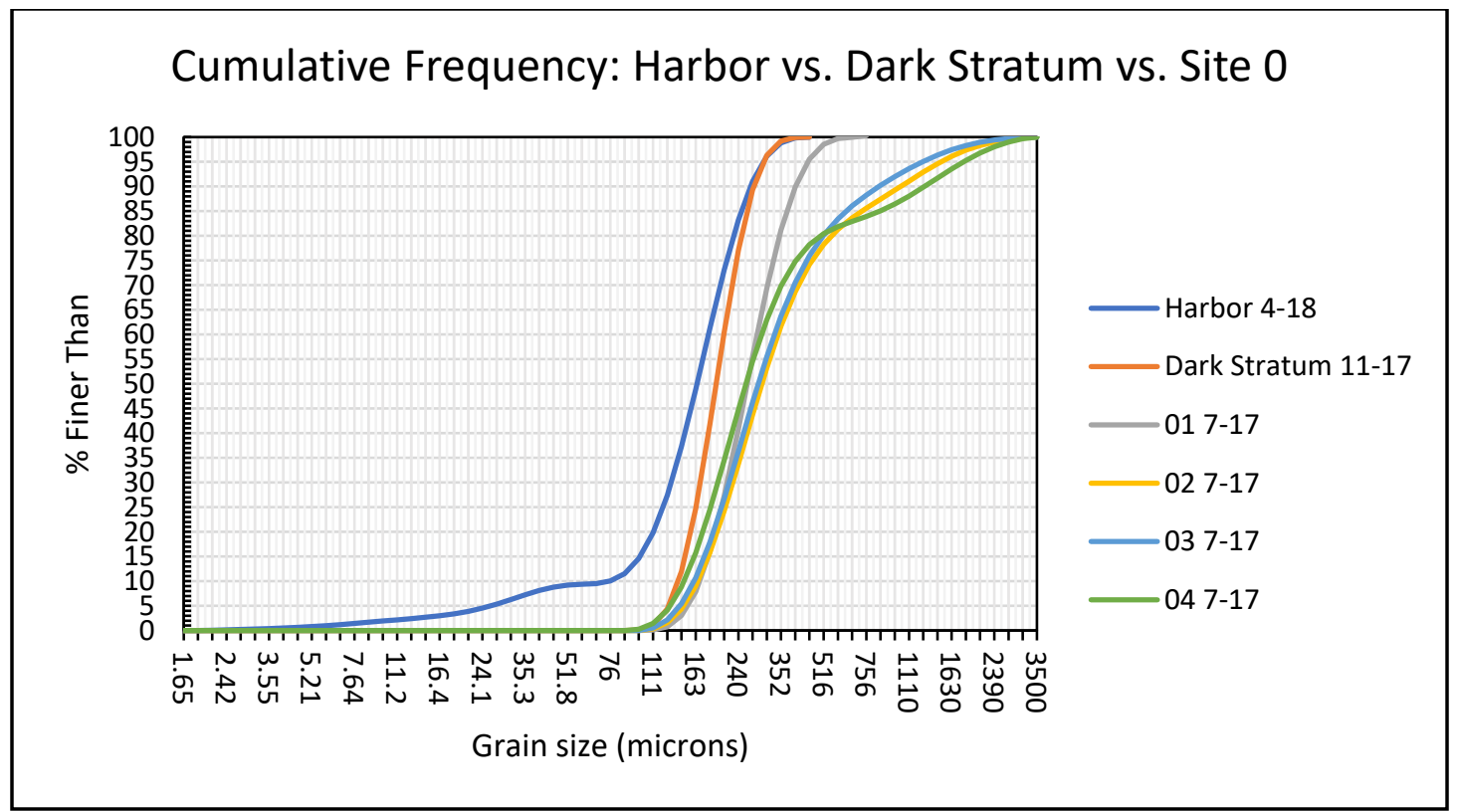

Figure 8: Cumulative frequency plot of the April 2018 Dredge Pit (Harbor) sample compared to the Dark Stratum, which was initially interpreted as dredge material, and July 2017 surficial data from Site 0 . The yaxis shows the percent of the sample that was finer than a given grain size (shown on the $\mathrm{x}$-axis in microns). The July samples were included to represent the in-situ conditions at Site 0 nearest in time to the dredge event in February 2016. The Harbor sample had a median grain size of $163 \mu \mathrm{m}$, which is significantly smaller than any other material found.

The typical average $\sim 200 \mu \mathrm{m}$ grainsize across the beach is also evident in looking at the grainsize results over the entire year post-dredging (Figure 9). Plotting median grainsize averaged for all sites shows beach grains typically falling out between 200$300 \mu \mathrm{m}$, with a deviation pattern within $\sim 100 \mu \mathrm{m}$ (Figure 9, “All Sites” panel). The graphs also show more variation of grainsizes along the southern section of the coast, with variability increasing northward towards the inlet $(3 \mathrm{~S} \rightarrow 2 \mathrm{~S} \rightarrow 1 \mathrm{~S})$. This variability is not seen in the north $(0,1 \mathrm{~N}, 2 \mathrm{~N}$, and $4 \mathrm{~N}$; Figure 9). Put altogether, these results show a coarsening trend throughout the Study Area in Winter 2018 when median grainsize reached a maximum of $316 \mu \mathrm{m}$ in January (Figure 9, “All Sites”). There was a second, weaker coarsening trend throughout the study area in late Spring 2018, when in May median grainsize across all sites reached $289 \mu \mathrm{m}$. Median grainsize across all sites was lowest in Fall 2017 and early-mid Spring 2018, when median grainsize was measured at $226 \mu \mathrm{m}$ in October and $225 \mu \mathrm{m}$ in March. 
35

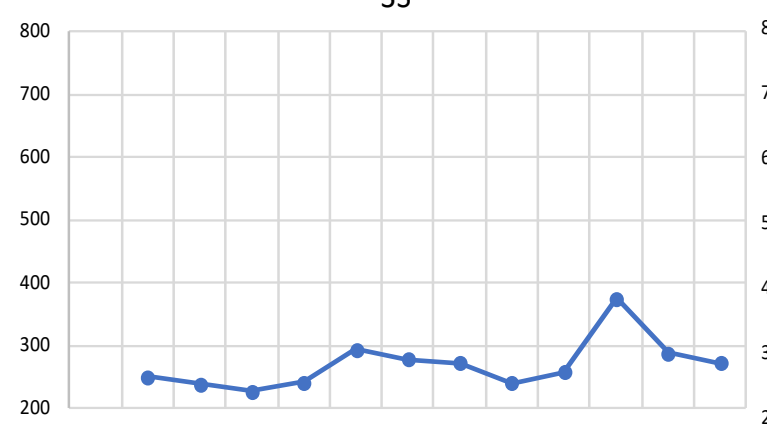

$1 S$

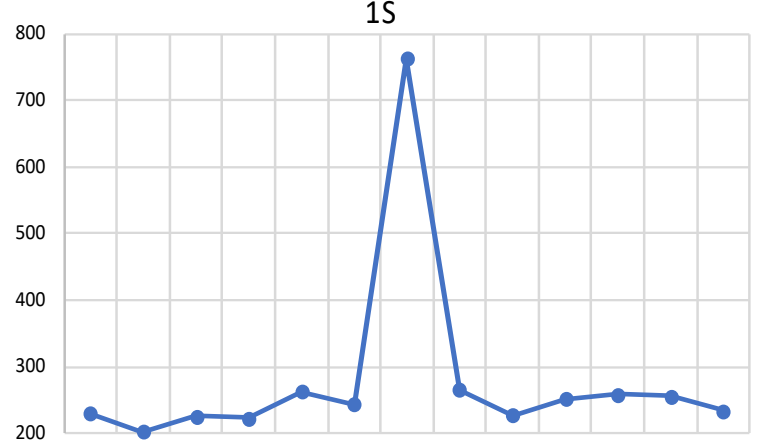

$1 N$

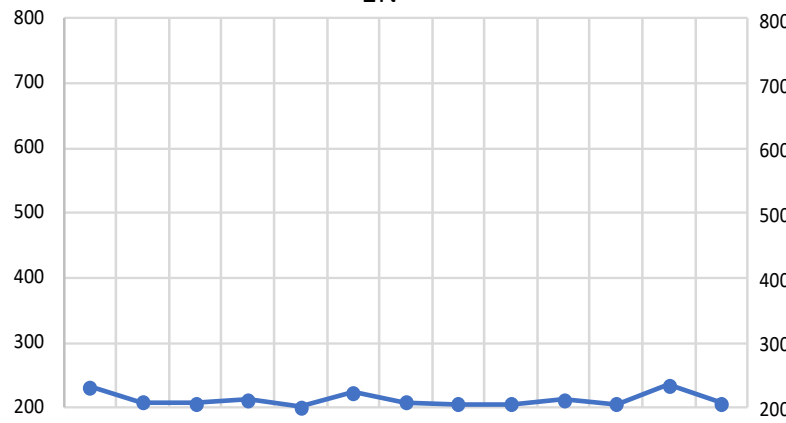

$4 N$

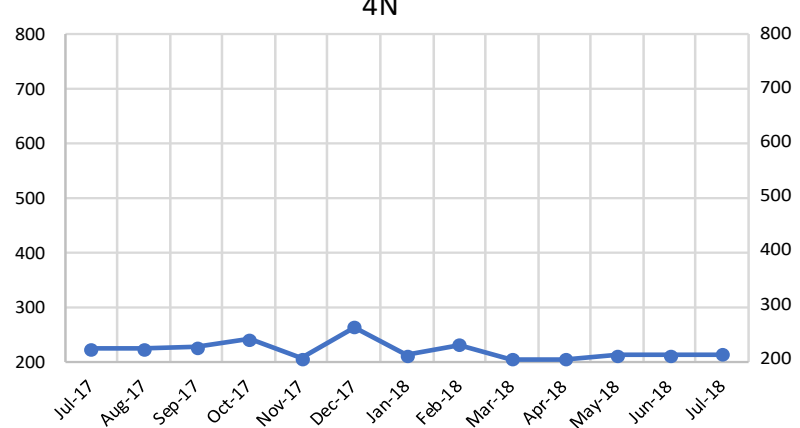

$2 S$

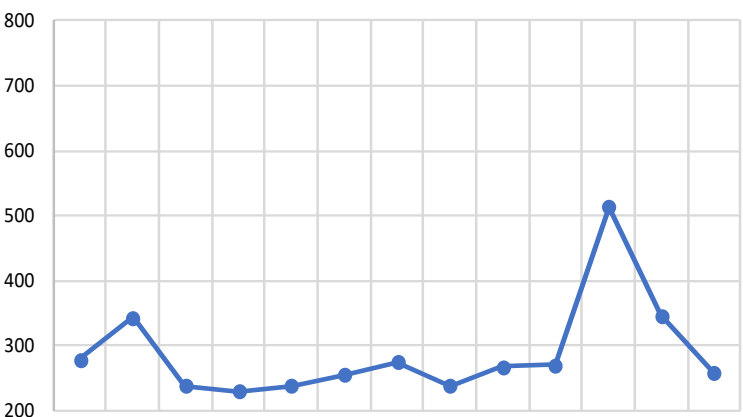

Site 0

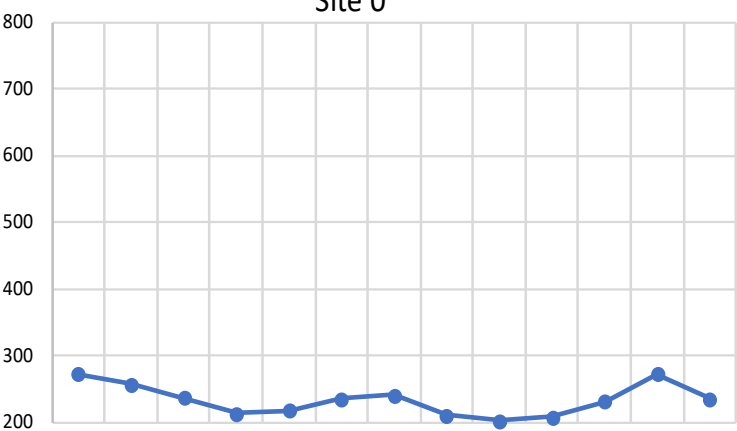

$2 \mathrm{~N}$

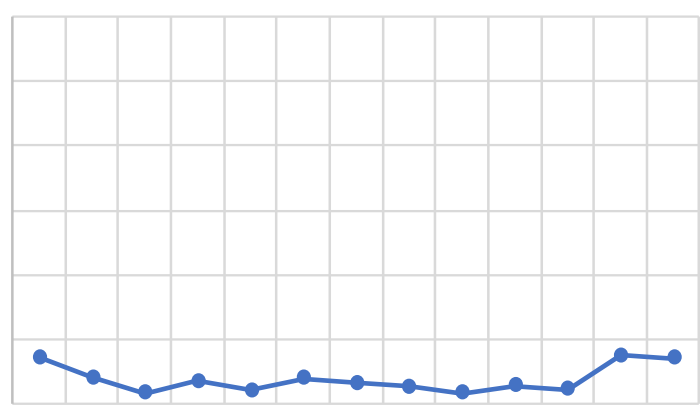

All Sites

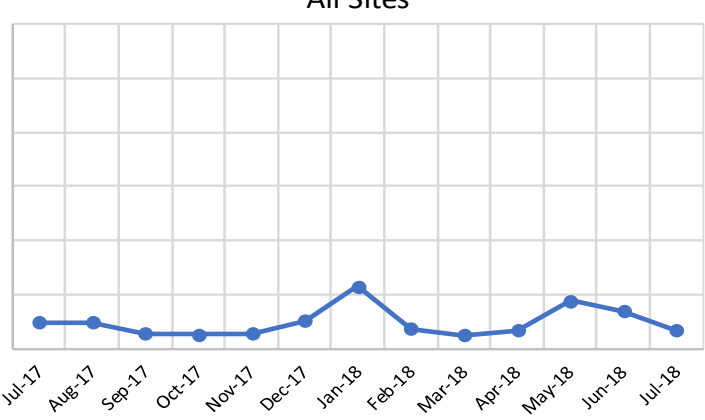

Figure 9: Temporal-spatial distribution of median grain size. The y-axes show grain size in microns; the $\mathrm{x}-$ axes show the month during which samples were collected. Site (e.g., 1N) data values are averages of median grain size for all samples collected at that site in a given month. The 'All Sites' data is composed of the average median grain size for a given month from all the sites. The 'All Sites' trend shows that average median grain size peaked in the winter and late spring. This trend was reflected best at Site 0 . Other sites vary in their trends but overall show a coarsening in winter and late spring/summer. 


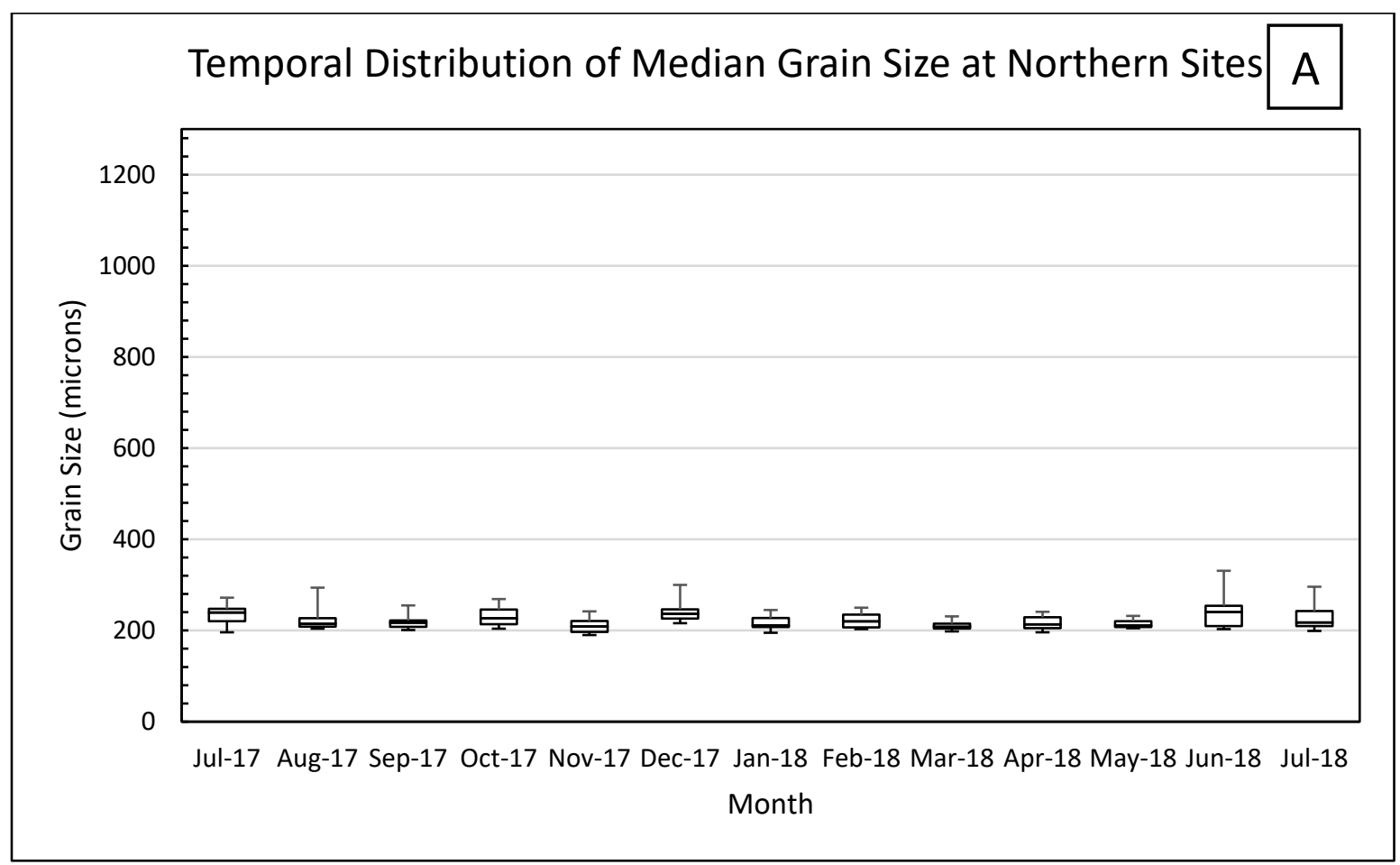

Figure 10a (caption below)

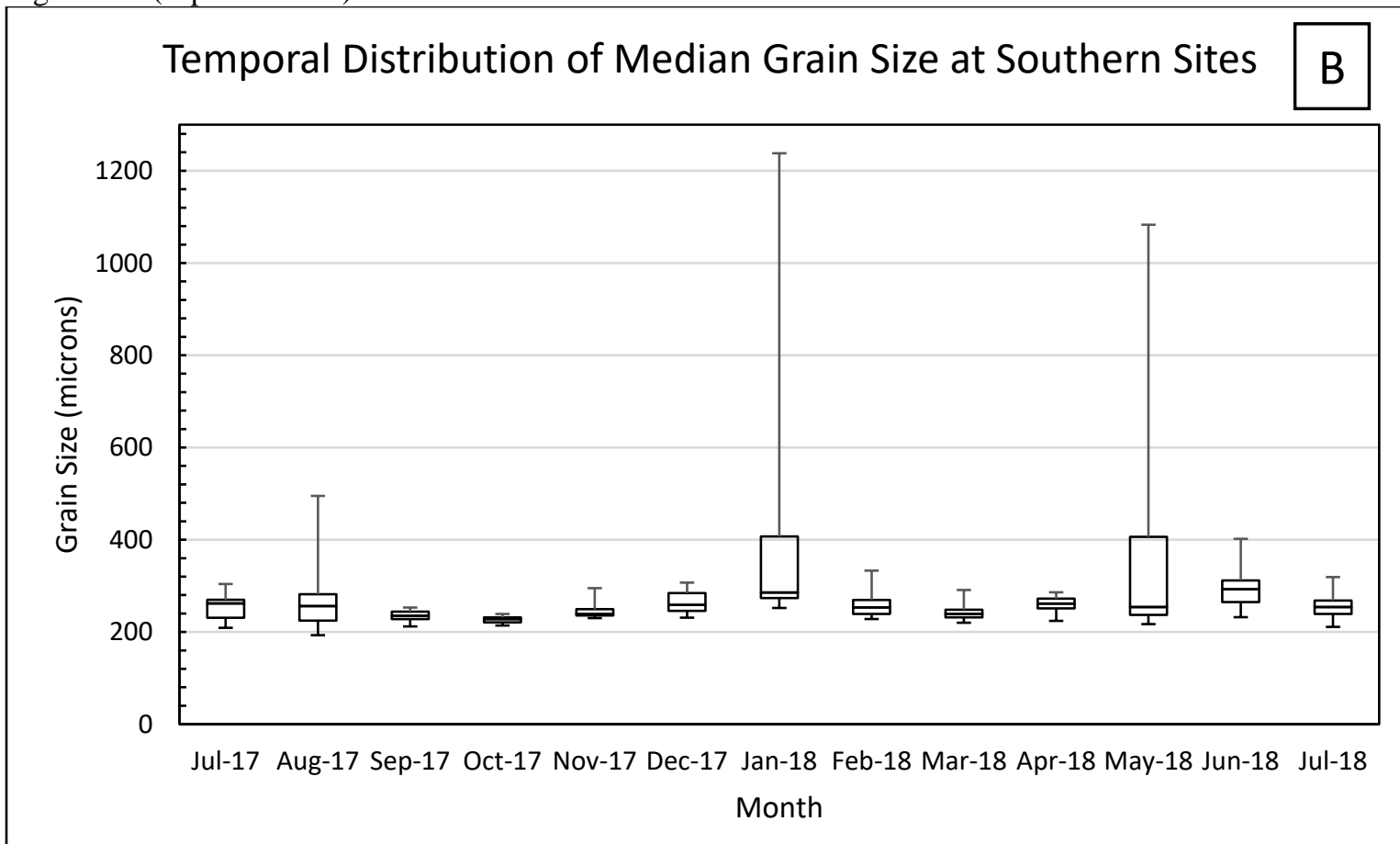




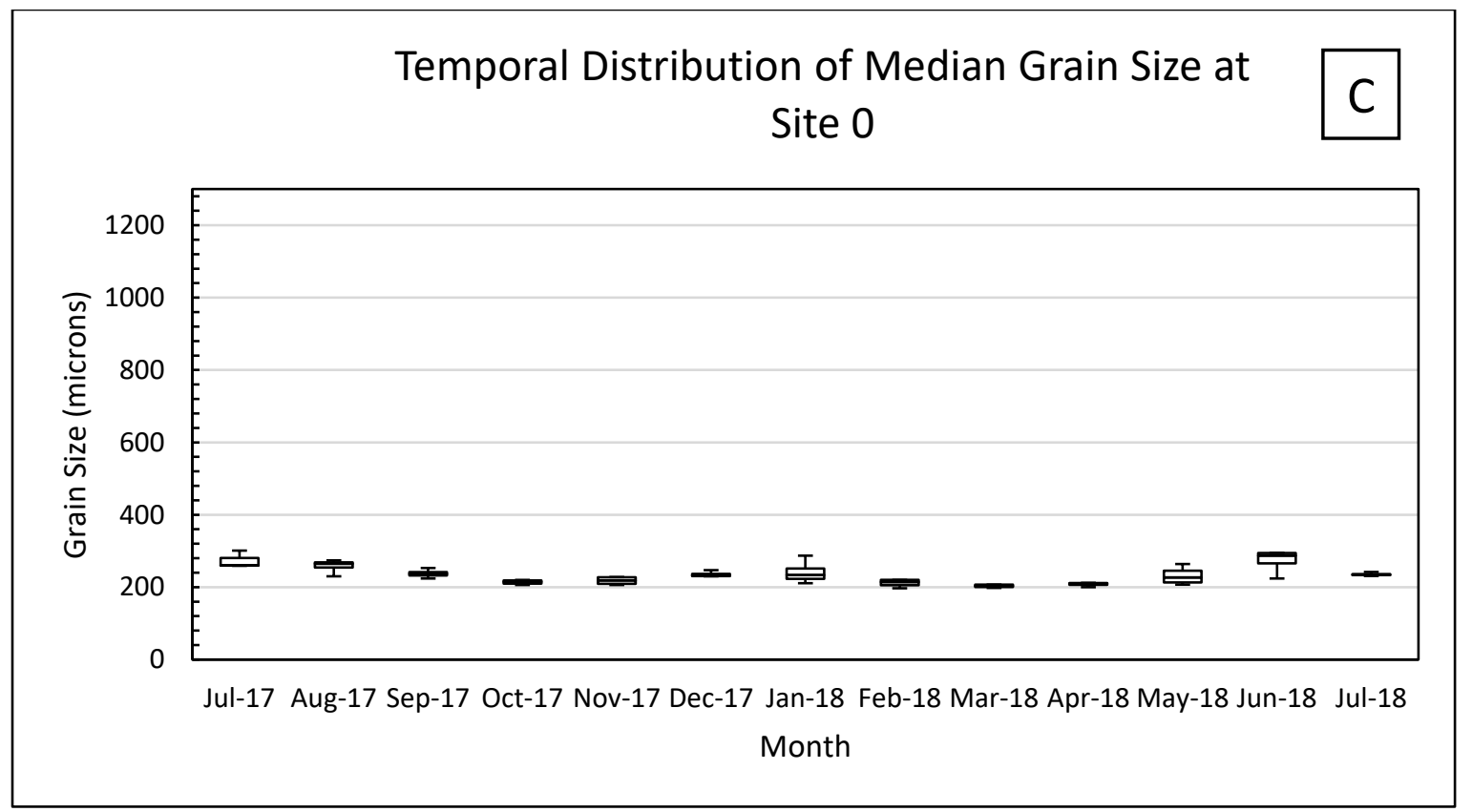

Figure 10: Box and whisker plots of temporal-spatial median grainsize by the Northern Sites (1N, 2N, and $4 \mathrm{~N} ; \mathrm{a}, \mathrm{n}=155)$, the Southern Sites $(1 \mathrm{~S}, 2 \mathrm{~S}$, and $3 \mathrm{~S} ; \mathrm{b}, \mathrm{n}=152)$, and Site $0(\mathrm{a}, \mathrm{n}=52)$. The $\mathrm{y}$-axes show grainsize in microns; the $\mathrm{x}$-axes show the month during which samples were collected. The same overall trend observed in Figure 10-coarsening in winter and late spring/summer- is reflected here. Both interquartile range (IQR) and the overall range are smallest at Site 0 (c). These parameters increased at the Northern Sites (a) and were at a maximum at the Southern Sites (b), indicating that the Southern sites were more variable in their grainsize 


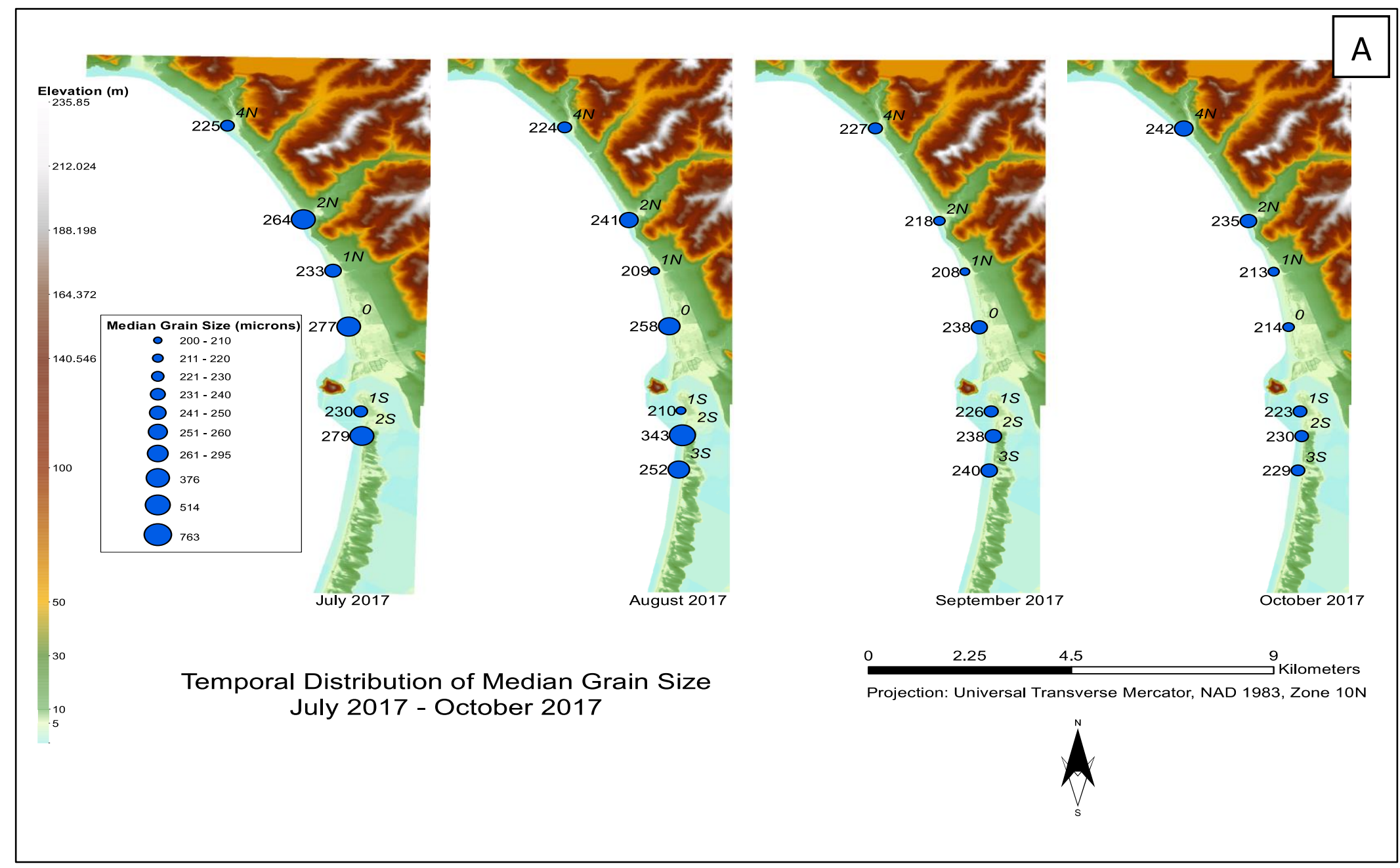

Figure 11a: Temporal Distribution of median grain size from July 2017 to October 2017. Grain size data were not collected at Site 3S in July 2017. 


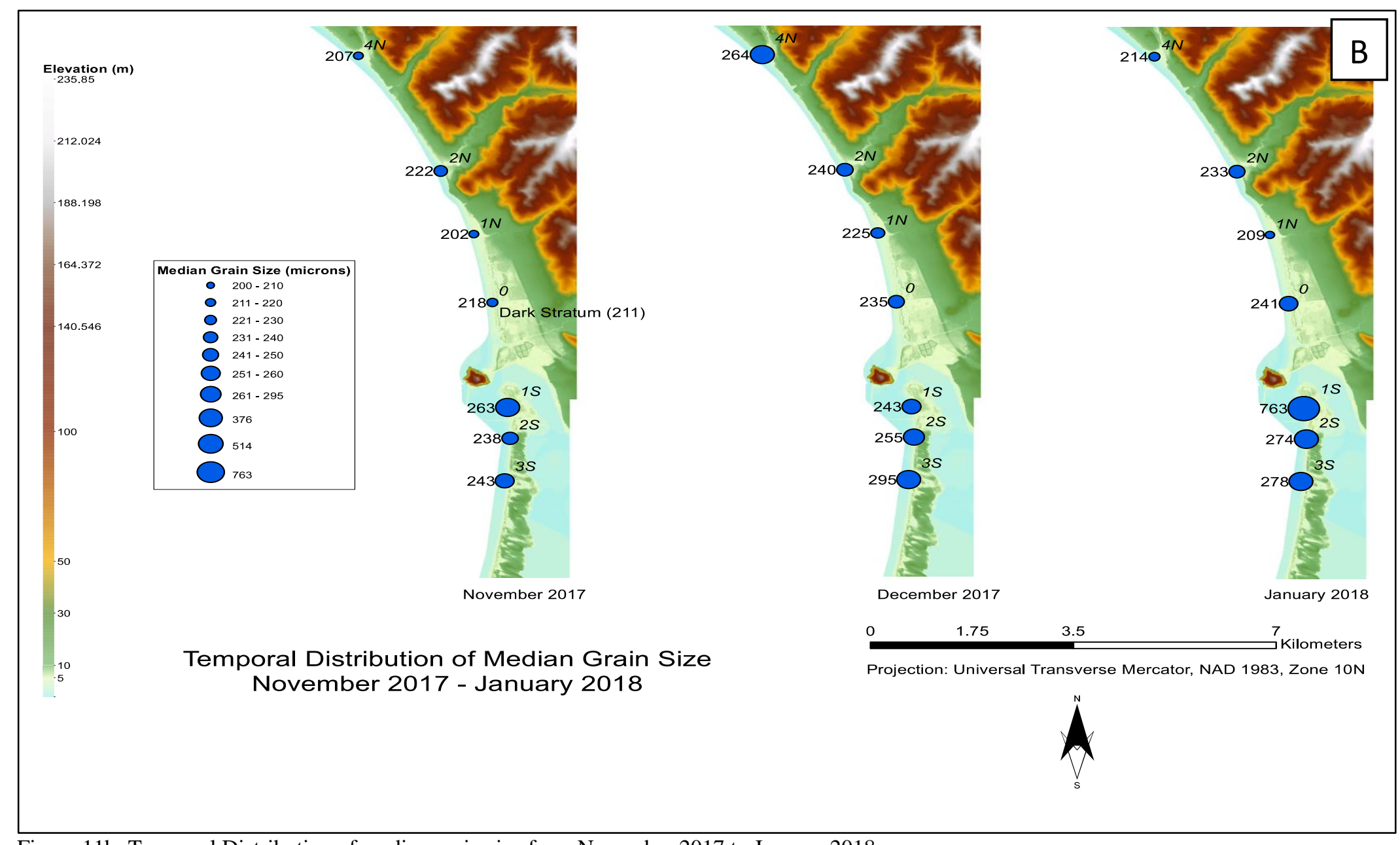

Figure 11b: Temporal Distribution of median grain size from November 2017 to January 2018. 


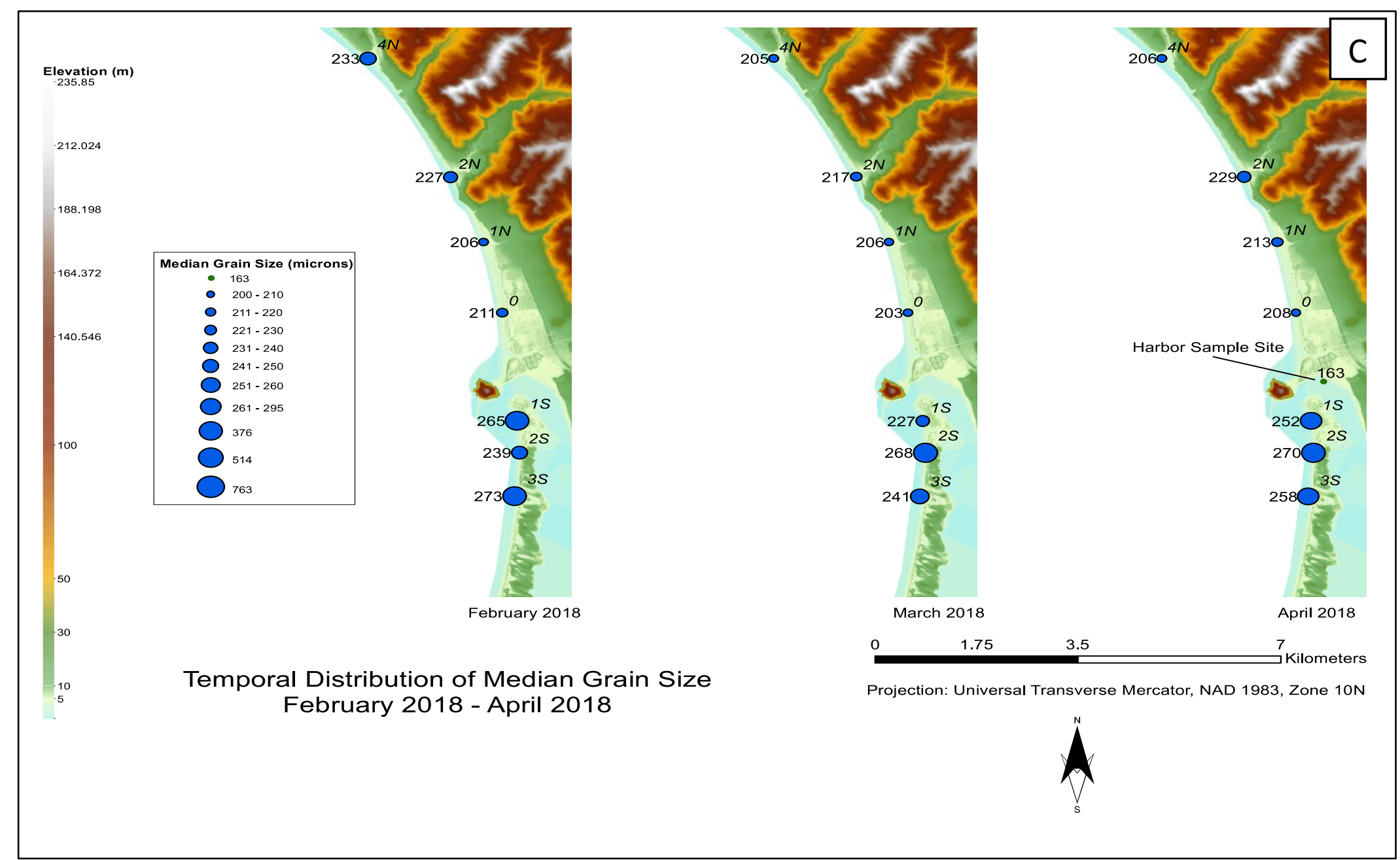

Figure 11c: Temporal Distribution of median grain size from February 2018 to April 2018. 


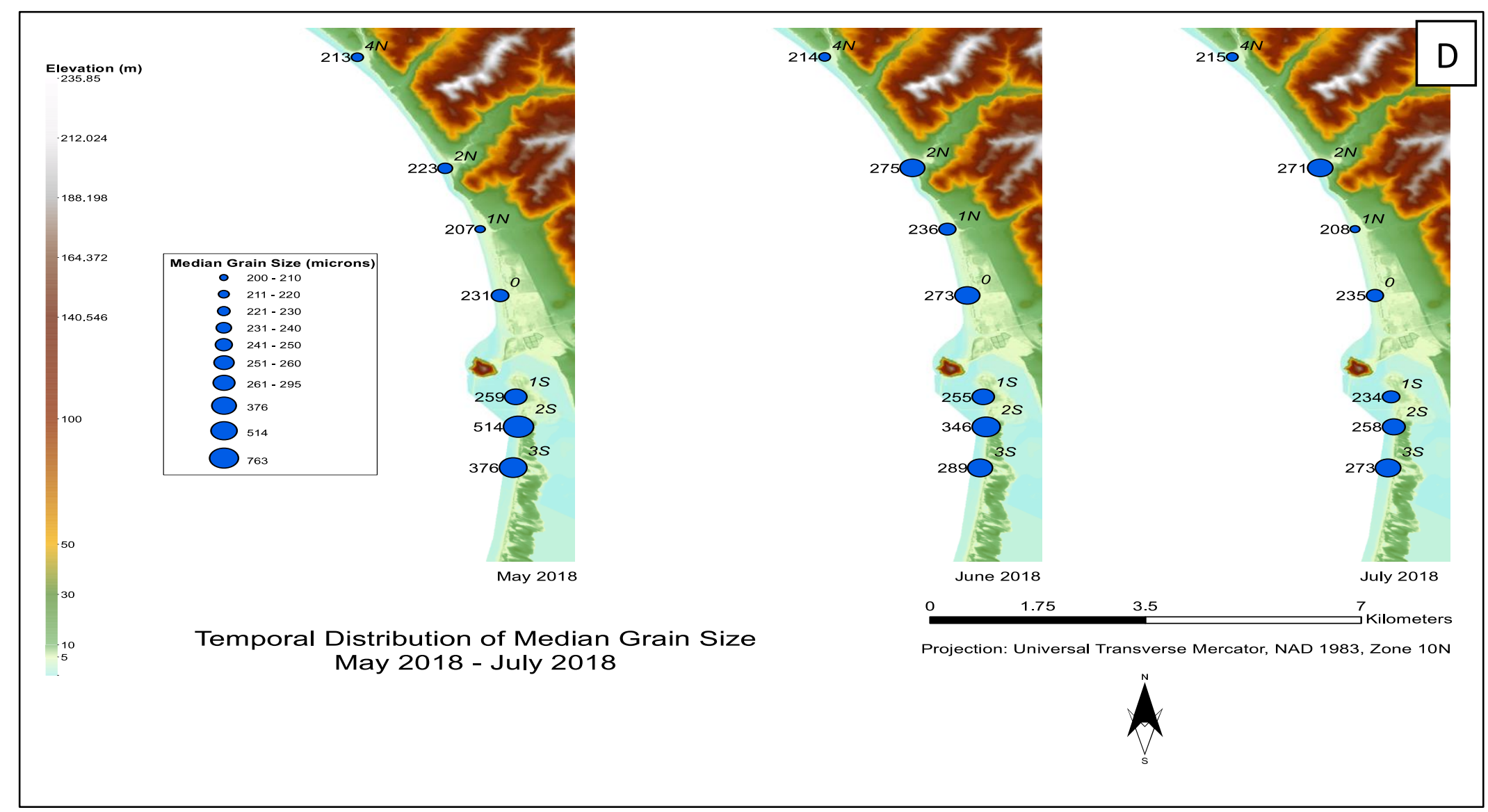

Figure 11d: Temporal-spatial distribution of median grain size. Circle sizes correspond to different grain size classes in microns. Average median grain size values were calculated by averaging the median grain size values along each site's transect for a given month. The winter and late spring/summer coarsening trends observed in Figures 9 and 10 are again reflected here. It is also apparent that the Southern Sites were consistently coarser than Site 0 and the Northern Sites. Maximum median grain size was reached at Site 1S in January 2018; the minimum median grain size was reached at Site 1N in November 2017. 
Subtle differences in grainsize trends (coarsening vs. fining) and variability between the northern and southern beaches become much more apparent when looking at box-and-whisker graphs of grainsize for the northern sites, the southern sites, and site 0 (Figures 10a-c), as well as in site maps, where grainsize is plotted more geospatially (Figures 11a-d). Graphic results show the more variable grainsize south of the Harbor. The same overall $\sim 200 \mu \mathrm{m}$ median grainsize persists throughout much of the year, with "tight" interquartile ranges (Figure 10a) indicating that the northern sites altogether had a relatively stable, unvarying $\sim 200 \mu \mathrm{m}$ facies. This is different than the combined grainsize response seen in the southern beaches (Figure 10b), where the interquartile ranges were more extended and more storm-responsive (Winter and Spring-Summer beach sands in the south can be as large as $1200 \mu \mathrm{m}$, whereas in the north the maximum grainsize seen is $\sim 350 \mu \mathrm{m}$ - almost $1 \mathrm{~cm}$ difference). For comparison, a graph of grainsize trends at Site 0 was also plotted (Figure 10c), showing a pattern consistent with other northern sites (Figure 10a).

Similar north, south, and seasonal differences in grainsize are also seen in geospatial images showing grainsize results at each site, averaged for each monthly sampling period (Figures 11a-d). Graphing this way gives a better sense of "where" exactly the grainsizes shown throughout Figures 8-10 occur along the beach, showing through time the typical surficial grainsize at each location. Starting at the benchmarked July post-dredge sampling period, surficial sands along both north and south shores

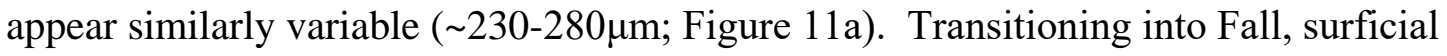
sands show a "fining," with the southern beach sands becoming a more similar facies $(\sim 230 \mu \mathrm{m})$, while the northern sites coarsen northwards $(210-240 \mu \mathrm{m}$; Figure 11a, October Panel). Throughout winter, the northern $210-240 \mu \mathrm{m}$ sand ranges remain relatively consistent (Figure 11b, November-January), although the coarsening northwards pattern seen in October (Figure 11a) is not consistently observed. Where the northern grainsizes 
remain relatively stable from October-January, grains on the southern shores coarsen over time, with median sizes ranging from $270 \mu \mathrm{m}$ to $760 \mu \mathrm{m}$. This $\sim 500 \mu \mathrm{m}$ variation in the south is an order of magnitude bigger than the $\sim 30 \mu \mathrm{m}$ variability seen in the north, showing the differential responses of the two beaches to winter storming. February through April again shows different grainsize populations in the northern and southern beaches. Beaches in the north keep the same $\sim 210-240 \mu \mathrm{m}$ variability, while the northern beaches fine back down after January and vary between 230-270 $\mu \mathrm{m}$ (Figure 11c, February-April). Starting Late Spring, the northern sites continue with the $\sim 210-240 \mu \mathrm{m}$ variability, with the southern beaches again experiencing coarsening $(250-380 \mu \mathrm{m}$; Figure 11d, May panel). It is not until June and July that northern variability changes, but the change is still small $(\sim 210-270 \mu \mathrm{m})$ compared to the grainsize variability in the southern

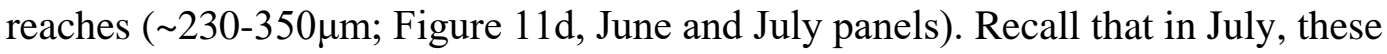
beaches were somewhat similarly variable (Figure 11a).

While the geospatial panels in Figures 11a-d are helpful in giving spatial context to the results, we also plot results monthly for each site, as it allows clearer insight--in one figure--into each site's temporal variability. Figure 12 graphs all the monthly median grainsizes by site, with symbols color-coded to give an indication of how each site's grainsize changes over the course of a year. Once again, results show that median grainsize was highest in the south, with the highest median grainsize $(1238 \mu \mathrm{m})$ observed in January at Site 1S-4 (more shoreward point of the 1S transect; Figure 6). This relates back to the highest whisker seen in Figure 10b, followed by the second highest whisker in May at 2S-4. Different than the south, median grainsize is consistently lower in the north, with some of the smallest at Sites 0 and 1N. Plotted this way, the different variability between the north and the south is readily apparent, with much larger grainsize ranges and differences occurring in the south. Also, plotting transect points of each site along the 


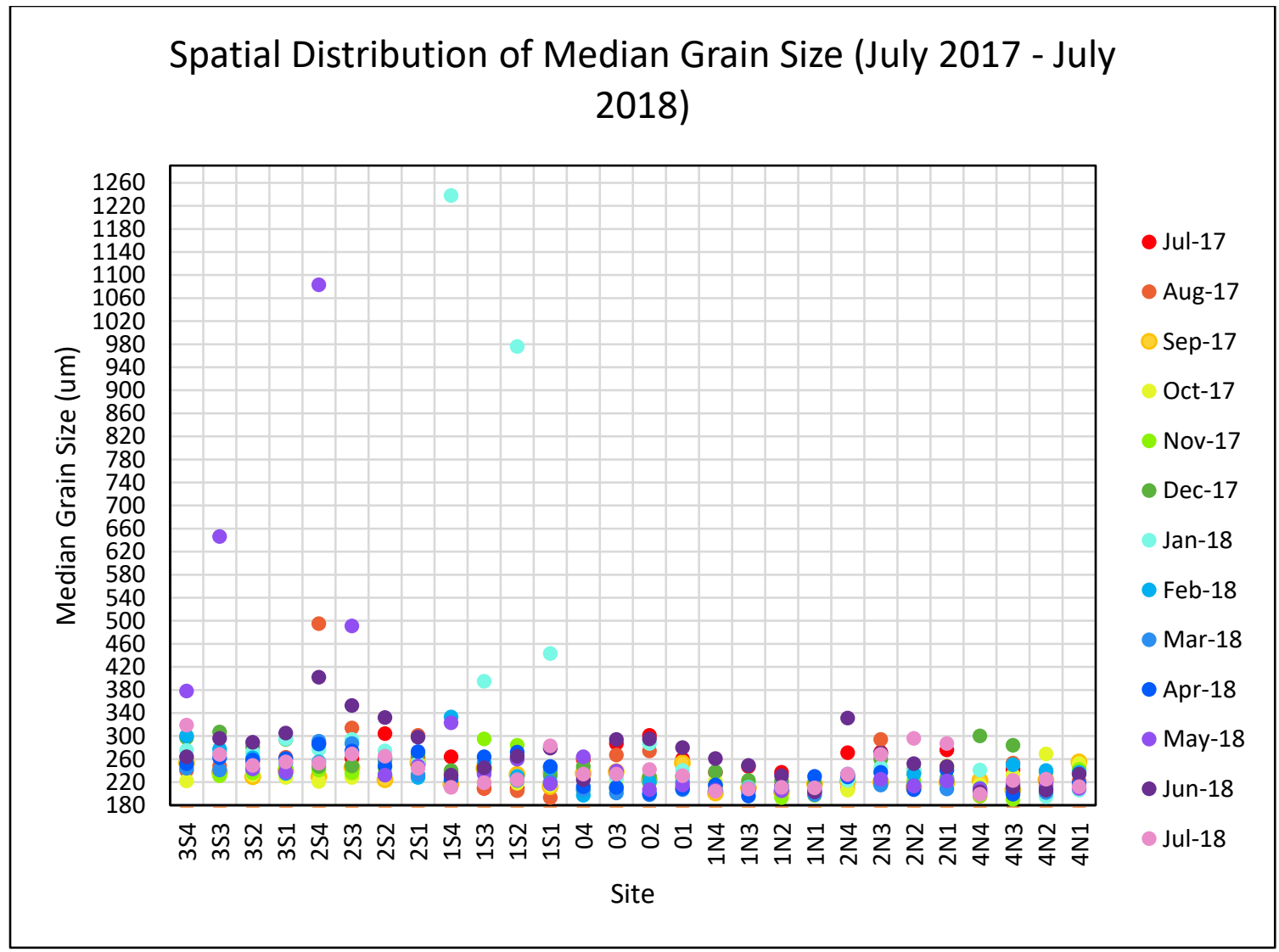

Figure 12: Temporal-spatial distribution of median grain size for all samples collected $(\mathrm{n}=359)$. The $y$-axis shows median grain size in microns; the $\mathrm{x}$-axis shows transect divisions by Site. Data points are colorcoded by month. Recall from Figure 6 that the ' 1 ' suffix indicates the area of the transect nearest to the dunes while the ' 4 ' indicates the area nearest the ocean. The data points are the raw median grain size values from the Malvern. The southern sites exhibited the highest overall median grain size, while Sites 0 and $1 \mathrm{~N}$ exhibited the lowest.

$\mathrm{x}$-axis shows the general coarsening trend toward the ocean (fourth section of each transect), typically in January, May, and/or June. The transect coarsening is much more punctuated in the south, with duneward-shoreward coarsening spanning $100 \mathrm{~s}$ of $\mu \mathrm{m}$ more than the 10 or so $\mu \mathrm{m}$ shoreward coarsening seen in the north (Appendix D).

\section{$\underline{5.2-\text { Mineralogy }}$}

In order to identify facies and to test whether any dredge was preserved as a buried sand layer, mineralogic analyses were conducted on surficial sediment samples collected from the Harbor (Harbor) and a sample taken from a depth of approximately 40 $\mathrm{cm}$ at Site 0 (Dark Stratum and suspected remnant dredge; Figure 13). The Harbor 
Sample had a quartz/intermediate/lithic (QIL) percent abundance of 9, 75, and 16, respectively. The Dark Stratum sample had a QIL percent abundance of 24, 51, and 25.

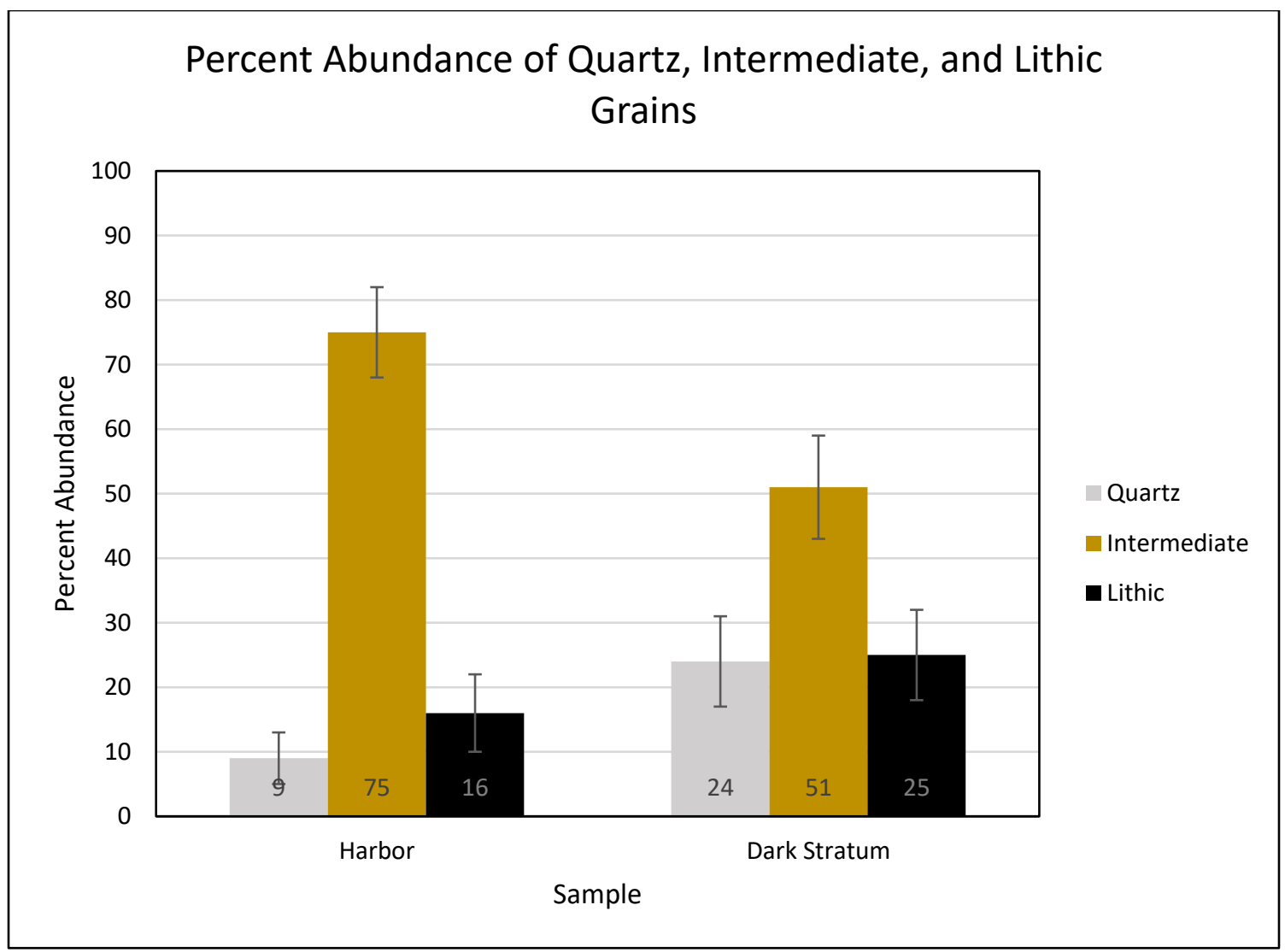

Figure 13: Percent abundance of quartz, intermediate, and lithic grains in the Harbor, Dark Stratum, and Stream Bed samples. The Harbor and Stream Bed samples are each surficial, with the Harbor sample being collected from the dredge pit in Morro Bay Harbor (dredge sediment proxy) and the Stream Bed sample being collected from the bed of Morro Creek near Site 0. The Dark Stratum sample was collected from a depth of approximately $40 \mathrm{~cm}$ at the duneward pit at Site 0 . The Harbor sample appears to be a distinct facies while the Dark Stratum and Stream Bed appear to be the same facies.

\section{$\underline{5.3-\text { Loss on Ignition }}$}

Along with mineralogy, samples were combusted to further differentiate facies within the samples studied and to gain more insight into possible biological-geological interconnections. Overall, the proxy for organic $\mathrm{C}$ ranged from $0.1-2 \%$, with inorganic $\mathrm{C}$ contents ranging between $0.4-3.25 \%$. This ranging of inorganic C correlated well to shell abundances observed during mineral counting, giving a degree of confidence to the use of 
combustion as a proxy for shell content. Plotting organic and inorganic percents as a function of latitude, the organic and inorganic $\mathrm{C}$ sediment fractions at each site and south-to-north can be observed (Figure 14a). Overall, there appears to be a weak, albeit diffuse, increasing trend in both carbon pools from south-to-north, paralleling a trend of finer grainsizes towards the north (i.e., Figure 12). Averaging the inorganic and organic percents for each site and plotting with standard deviation, the northwards, overarching increasing trend of shell and organic content becomes a little clearer (Figure 14b). The northern beach sediments support higher amounts of organic and mineral carbon content, showing another notable difference between the northern and southern shores.

\section{$\underline{5.4-\text { Stratigraphy }}$}

A total of 58 stratigraphic pits were dug over the course of the study. The data from these pits were compiled (see Appendix C, Table 1) and generalized into six types of stacking patterns (SPs) observed throughout the study, idealized in Figure 15a-d. These stacking patters-numbered I through VI, are described below. The descriptions are followed by histograms showing the proximity over which the SPs were observed at each location (both dune and oceanward; Figure 16), and during each season (Figure 17; Fall 2017, Winter 2017, Spring 2018, and Summer 2018).

Stacking pattern I was described as a massive sand layer indicative of rapid, uniform deposition. It was composed predominately of very fine to fine sand made predominantly of quartz with a small percentage of lithics and a shell fragment abundance ranging from 0-20\%. Stacking pattern II was an overall massive sand layer with laminae of coarser intermediate grains distributed throughout, indicating periods of higher depositional energy. Sand within the massive layers was predominately very fine to fine. It was composed mostly of quartz with a small percentage of lithics and a shell fragment abundance ranging from $0-20 \%$. The sediments within the laminae were 


\section{Spatial Distribution LOI}

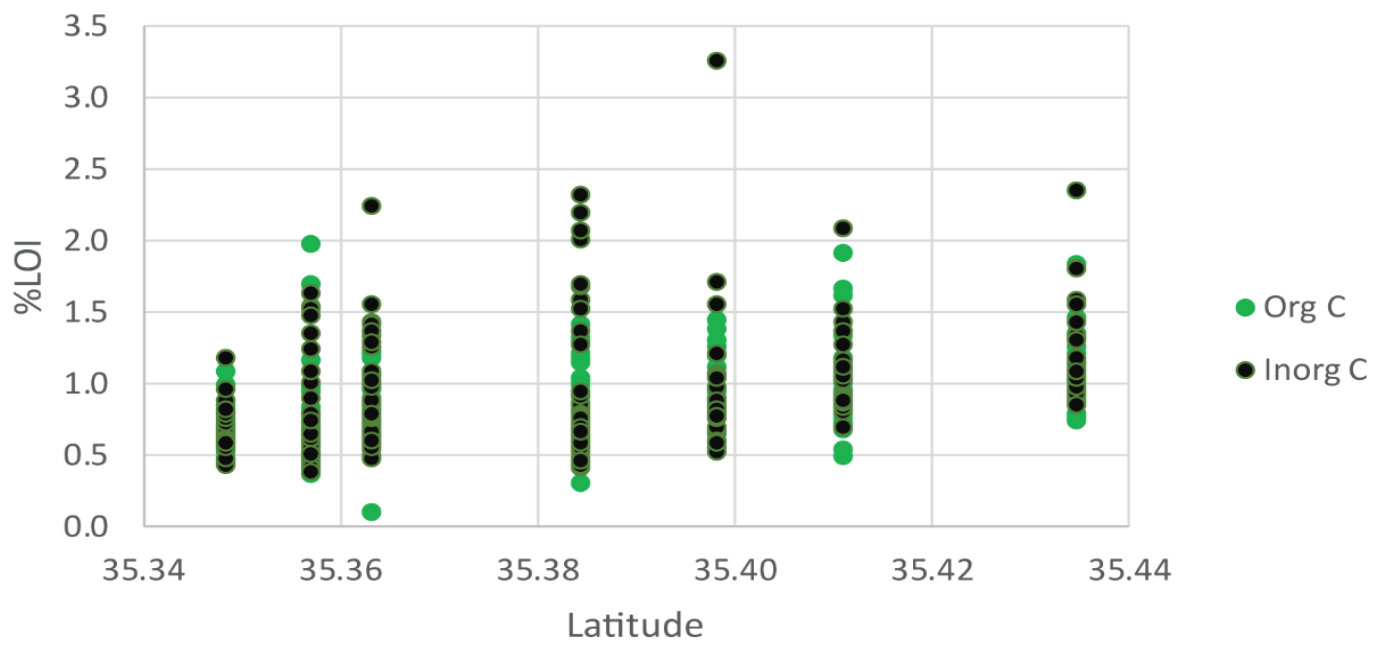

\section{Spatial Distribution Averaged-LOI}

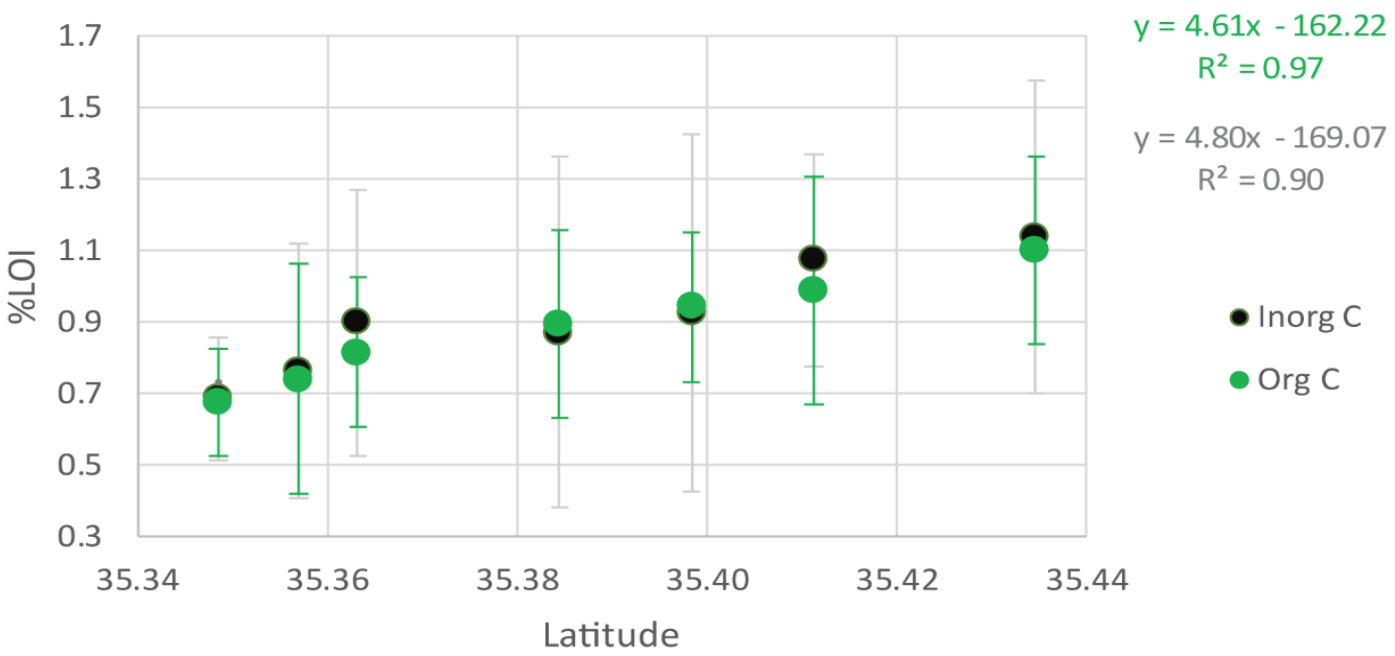

Figure 14: Percent loss-on-ignition (LOI) results plotted along a south-to-north transect. The top graph shows all of the LOI results, with organic C (green circles) and inorganic (black circles), at each site for all samples between July 2017 and February 2018 (n 240). Results of inorganic C correlates well to amounts of shell observed doing mineral microscopy (typically $~ 1 \%$ ) indicating good agreement between the methods. Plotting organic and inorganic $\mathrm{C}$ averages for each site with standard deviation in the bottom graph shows that at and close to the dumpsite, there is less shell material than trends would predict. Plotting using latitude, there is an increasing gradient of shell and organic materials towards the northern coastal reaches, with shell material typically falling out a little higher than the organic $\mathrm{C}$. The opposite is seen at the dumpsite and its closest neighbor $1 \mathrm{~N}$, which may mean that the dredging favors more soft-bodied biota (refer to Hypothesis 1A). 
predominately medium sand and composed mostly of intermediate grains. Shell fragment abundance within the laminae ranged from $0-10 \%$. Stacking pattern III was an overall massive sand layer with laminae of dark black grains which suggested sorting of denser lithic material during transport. The frequency of the dark laminae generally increased up-column. The sediment within the matrix was predominately very fine to fine sand. It was composed mostly of quartz grains with a small percentage of lithics and a shell abundance ranging from $0-3 \%$. The sediments within the laminae were predominately very fine to fine sand and composed exclusively of lithic grains. No shells were found within the laminae. Stacking pattern IV was described as an overall massive sand layer with shallowly-buried trough crossbeds indicative of sorting during transport. The massive sands were very fine to fine grained. They were composed predominately of quartz with a small percentage of lithics and a shell fragment abundance of approximately $3 \%$. The sediments within the trough crossbeds were very fine to fine sands, predominately quartz, and contained no shell fragments. Stacking pattern V was defined by the presence of the Dark Stratum, which was described as a massive layer composed of very fine sand. It was composed of predominately non-quartz grains and contained no shell fragments (Figure 13). The Dark Stratum was overlain by a massive fine sand layer composed predominately of quartz. The overlying layer contained no shells. Stacking Pattern VI was described as an overall massive layer of very fine to fine sand with interbeds of gravel-pebble sized grains which were indicative of a high-energy depositional environment. The sand within the massive layer was composed predominately of quartz with a small percentage of lithics. It had a shell fragment abundance of 1-3\%. The gravel-pebble grains within the interbeds were sub-rounded and were composed exclusively of intermediate grains. There were no shell fragments. 

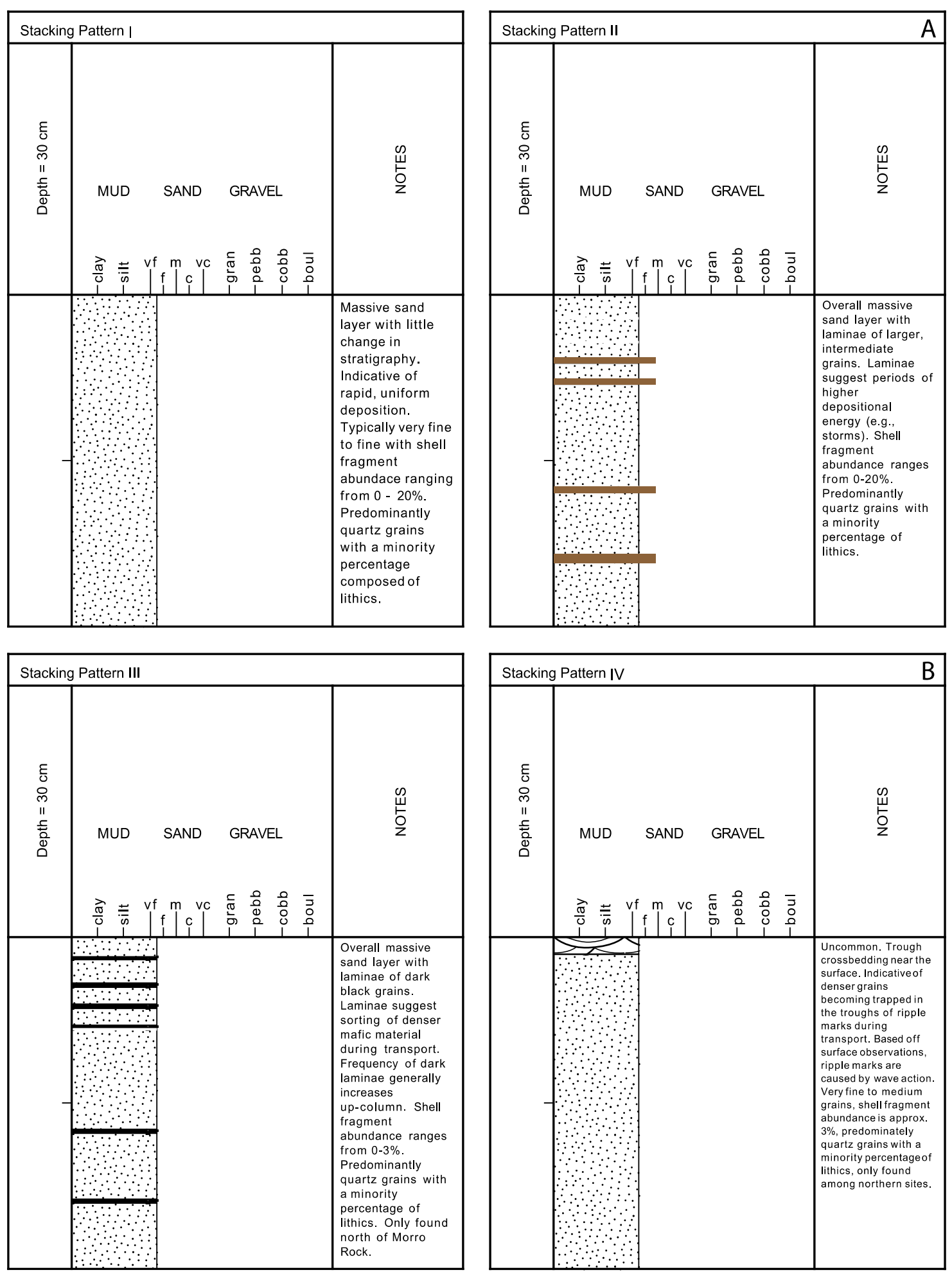

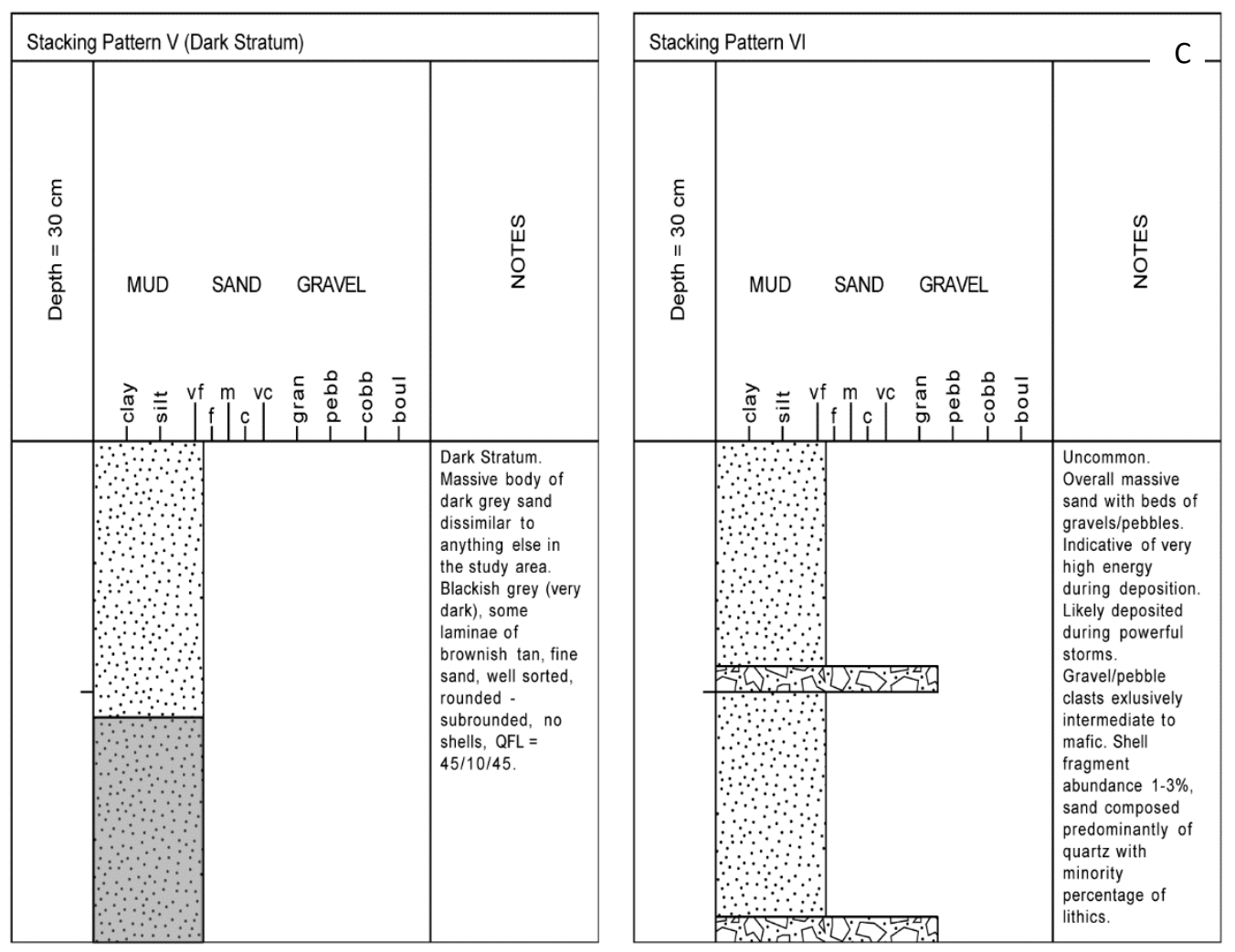

Figure 15: Stacking Patterns I and II (a), III and IV (b), and V and VI (c). Stacking Patterns were selected to represent repeated observations among stratigraphy data. All stratigraphic pits exhibited very fine to fine sand with occasional laminae or beds of coarser, darker, or reworked sediments. Stacking Pattern V includes the Dark Stratum, which was interpreted as dredge material. 

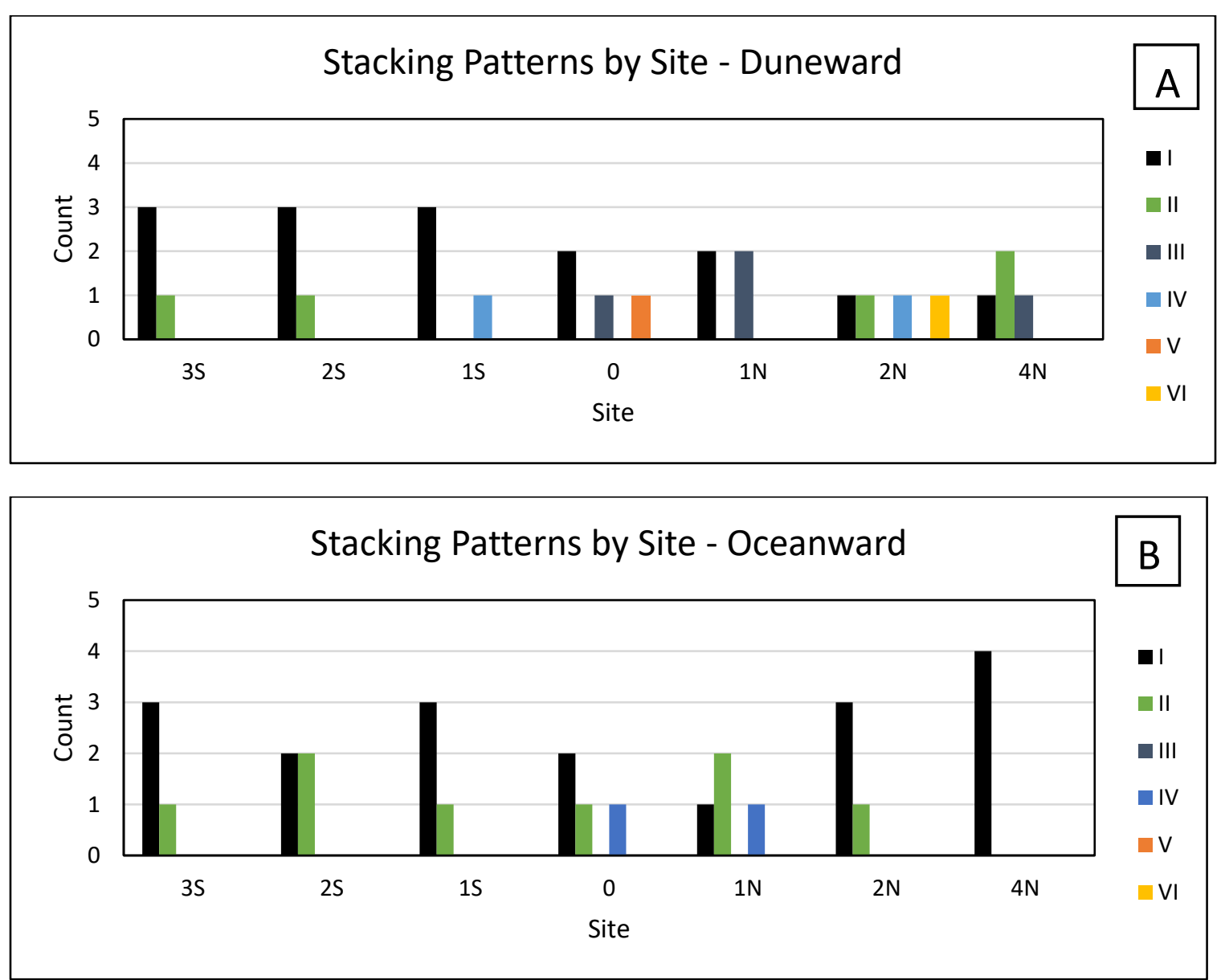

Figure 16: Stacking patterns by site location, over the entire year. Half-values at $2 \mathrm{~N}$ (a) are the result of two distinct SPs being present in the same pit. The duneward pit (a) had more diverse stratigraphy overall; the oceanward pit (b) was much more homogenous. The southern sites were less diverse than the northern Sites and Site $0(\mathrm{a} \& \mathrm{~b})$. Stacking Pattern I was the only SP observed at all sites at both pit locations.

Spatially, the northern sites and Site 0 exhibited the most diverse stratigraphy as all six SPs were present among those sites (Figure 16a). At the duneward location, Site $2 \mathrm{~N}$ exhibited the most stratigraphic diversity with four SPs being observed over the course of the study (SPs IV and VI were observed in the same pit in Spring 2018; see Appendix C, Table 1). Three SPs were observed at the duneward pit at Sites 4N and 0, and only two SPs were observed at the duneward pit at Site 1N (Figure 16a). The diversity at the northern sites decreased sharply at the oceanward pit (Figure 16b). Sites 0 and $1 \mathrm{~N}$ were the most diverse with three stacking patterns (SPs I, II, and IV were 
observed at each), while Site 2N exhibited two (I and II) and Site 4N exhibited one (I). Stacking pattern I was overall the most common at both the duneward and oceanward pits.

The southern sites were much less diverse. With the exception of Pit 1 at Site 1S, where SP IV was observed, each pit at each southern site exhibited SPs I and II only (Figure 16a \& b). As with the northern sites and Site 0, stacking pattern I was overall the most abundant at both the duneward and oceanward pits.

Examining spatial trends along the transects in general showed that the duneward pit exhibited the most diverse stratigraphy. All six SPs were observed at the duneward pit (Figure 16a) throughout the course of the study. The oceanward pit was overall more uniform throughout the study area - only SPs I, II, and IV were observed (Figure 16b).

The most common stacking pattern overall was SP I, which comprised 57\% of all SPs (Figure 17a), followed by SP II, (22\%, Figure 17a). Stacking pattern III made up 7\% of all SPs, while SPs IV and V each made up 5\%. Stacking Pattern VI made up 3\%.

Stacking Pattern I was the most abundant during each season (Figure 17b). Stacking Pattern II was the second-most common during each season except for Fall 2017, where it was equal in abundance with SP IV (15\%). Stacking Patterns I and II were the only two SPs observed during all four seasons. Stacking Patterns III and V were not observed after Spring 2018. Stacking Pattern IV was only observed in Fall 2017 and Spring 2018. Stacking Pattern VI was only observed in Spring 2018 and Summer 2018.

There was not a noticeable trend in SP diversity in a temporal sense. Unlike median grainsize, which returned close to initial values at the end of the sampling period (Figure 9), SP abundance did not 'reset.' Five SPs were observed during the initial sampling in Fall 2017. The total decreased to four in Winter 2018 before reaching a maximum in Spring 2018, when all six SPs were observed. This maximum was quickly followed by a minimum, in Summer 2018, when only three SPs were observed. 

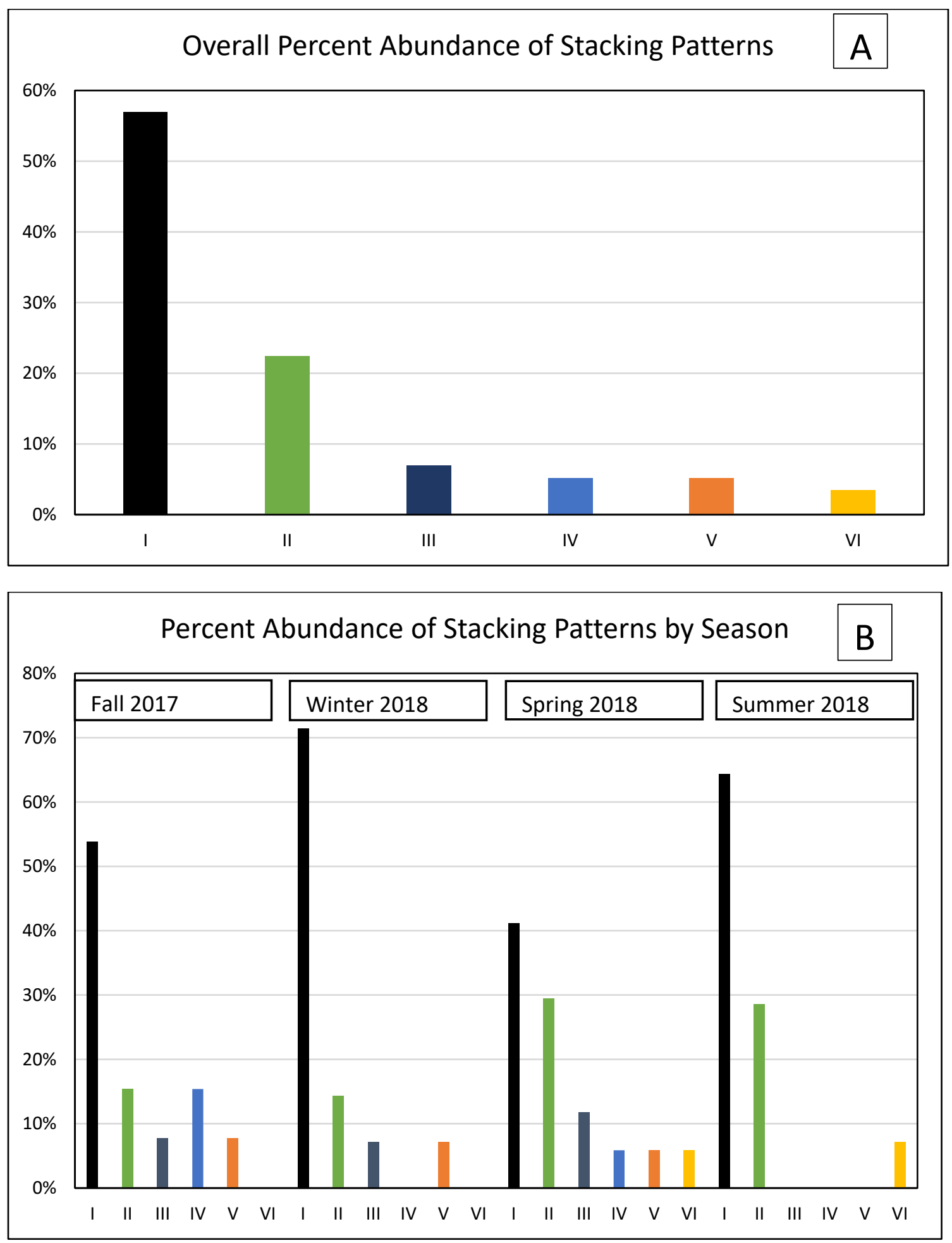

Figure 17: Percent abundance of stacking patterns $(n=58)$ overall (a) and by season (Fall 2017, Winter 2018, Spring 2018, and Summer 2018; b). The y-axes show percent abundance; x-axes show stacking patterns. Stacking Pattern I was the most abundant, followed by SP III. Stacking Pattern V, which contained the Dark Stratum, was the least abundant and was not detected after Spring 2018. 


\section{$\underline{5.5-\text { Biology }}$}

A total of 8903 birds and 58 invertebrates were counted during the study. Individuals were grouped by species and analyzed to understand how species diversity changed throughout the study area. Birds were counted monthly and invertebrates were counted seasonally during the months of November 2017 (Fall), February 2017 (Winter), April 2018 (Spring) and July 2018 (Summer). In all, there were 44 unique bird species and 20 unique invertebrate species identified. Detailed biology results will be published in a subsequent paper by the Reece Lab, but correlations between biodiversity and grainsize can be found here in Figure 22 in Section 6.4. 


\section{6 - DISCUSSION}

The discussion herein will interpret what the observed trends in grainsize, mineralogy, and stratigraphy reveal about the study area. It will then assess correlations between grainsize and biodiversity before detailing the outcome of our hypotheses. Finally, we hypothesize the fate of the dredge material.

\section{$\underline{6.1-\text { Grainsize }}$}

Temporal grainsize data suggest that the study area is dynamic and remarkably resilient to change. The study area was able to accommodate robust changes in grainsize in a matter of months. Take for example the median grainsize changes observed at Site $1 \mathrm{~S}$ during the winter. Figure 18 shows that median grainsize there increased from $243 \mu \mathrm{m}$ in December to $763 \mu \mathrm{m}$ in January. It then decreased to $265 \mu \mathrm{m}$ by February. This robust and rapid fluctuation suggests that the littoral system within Morro Bay is able to mitigate changes in grainsize within a short time span (i.e., weeks to months).

This apparent ability of the littoral system to mitigate changes has important implications for the impact of the February 2017 dredging operation. The Harbor Sample taken in April 2018 (Figure 8) is useful as a proxy to the dredge material that was dumped at Site 0 in February 2017. The median grainsize of that sample was $163 \mu \mathrm{m}$. The average median grainsize along the Site 0 transect in February 2018 was $211 \mu \mathrm{m}$. Using this value as a proxy for the grainsize of the in-situ sediment at the time of the dredge event allows the inference that the $163 \mu \mathrm{m}$ dredge material was deposited on a beach with an average median grainsize of approximately $211 \mu \mathrm{m}$. The difference in median grainsize between these two facies is much less than the differences in median grainsize observed between December 2017, January 2018, and February 2018 (Figure 18) - $48 \mu \mathrm{m}$ versus approximately $500 \mu \mathrm{m}$. Based on the timeframe during which 
median grainsize changed at Site $1 \mathrm{~S}$, the proxy data suggest that Site 0 could have returned to pre-dredge conditions within months.

It is unclear if the oscillation in median grainsize over the course of the study (Figure 9) was a result of the dredging operation or abnormal beach behavior. Beaches are subject to yearly cycles of narrowing in the winter and widening in the summer (Woodroffe, 2002). During the winter, higher-energy waves lead to larger grainsizes whereas lower-energy waves lead to smaller grainsizes in the summer (Best \& Griggs, 1991). Expected results would therefore show a maximum median grainsize in the winter and a minimum median grainsize in summer. Our results did show a maximum median grainsize in the winter, but the minimum occurred in the fall and winter, when statistically identical median grainsizes of 226 and $225 \mu \mathrm{m}$ were observed in October 2017 and March 2018, respectively (Figure 12). Median grainsize results reached a midpoint rather than a minimum during the summer.

Whether this trend is reflective of an impact from dredging, an abnormal year, or the normal trend in the study area is not known. There is precedent for the trend being normal for the study area. Dingler et al. (1982) observed coarser grainsizes in the summer of $1978(260 \mu \mathrm{m})$ versus the spring of $1979(240 \mu \mathrm{m})$ when they collected samples along nine transects in the Morro Bay area. Additional median grainsize data, perhaps taken over the course of two years instead of one, would elucidate whether the trend is normal or abnormal for the study area. There are also additional factors that could be considered, such as how flushing of the Bay through the entrance channel might impact grainsize (Griggs, 1987).

The southern sites showed more variability and larger overall median grainsizes than the northern sites and Site 0 (Figures 10,11, \& 12). The simplest explanation for this trend would be the presence of overall higher-energy waves along the sand spit on which the southern sites are located. The sand spit is also a younger depositional environment 


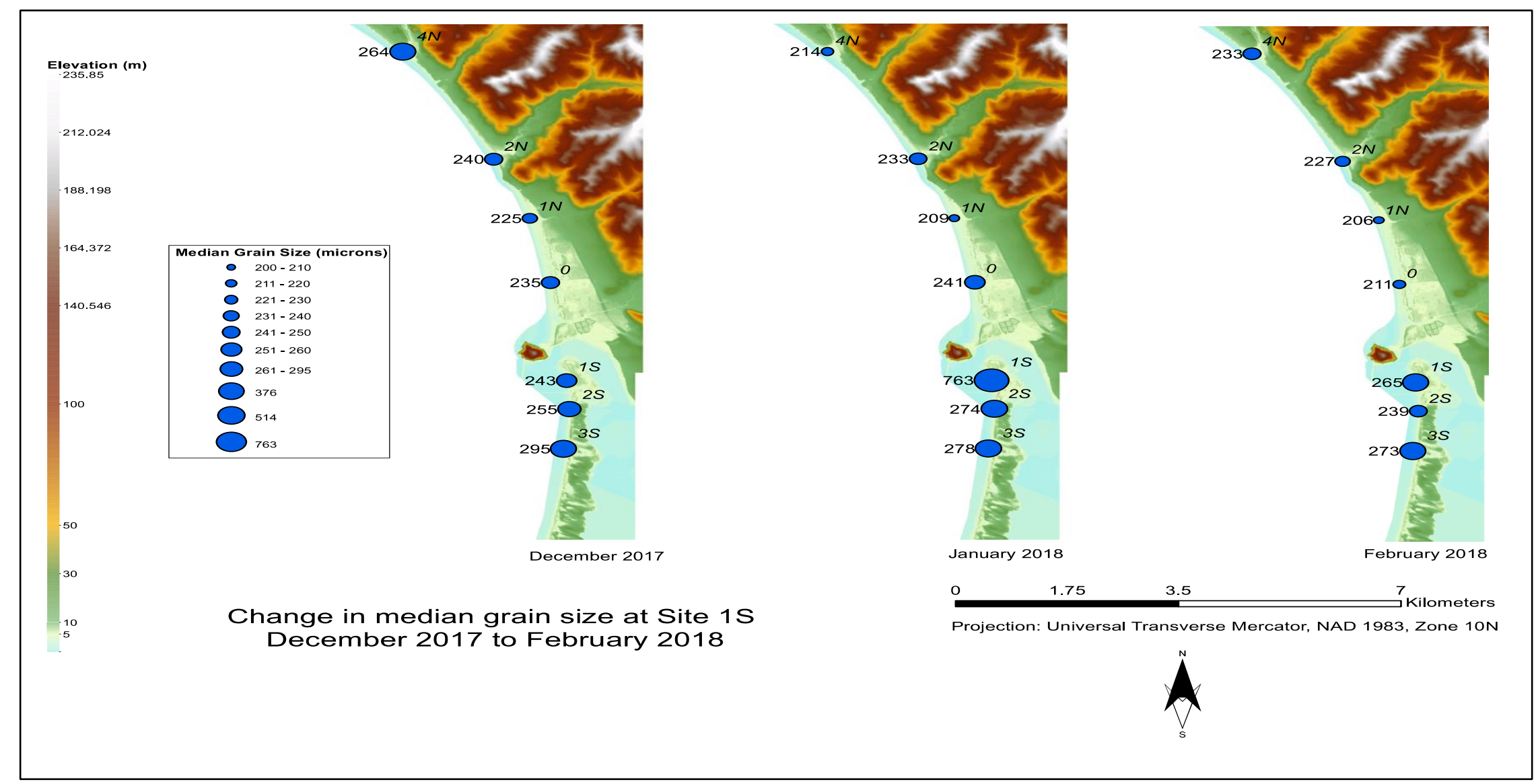

Figure 18: Change in median grain size at Site 1S between December 2017 and February 2018. Note that these are the same data from Figure 11 with panels rearranged for clarity. The mean median grain size at Site $1 \mathrm{~S}$ increased by $520 \mu \mathrm{m}$ from December to January, then decreased by $498 \mu \mathrm{m}$ from January to February. Such large-scale changes in the span of weeks to months suggests that the environment in the study area is incredibly dynamic. Our data suggest that the median grain size of the dredge material would have differed from that of the in-situ beach sand by approximately 48 um-it is apparent that the environment could have mitigated this size difference in a few weeks to months. 
than the marine-cut terraces in the north (5,000 kya vs. 125,000 kya, respectively; Orme, 2005) so the higher degree of immaturity indicated by the larger median grainsize is consistent with expectations.

\section{$\underline{6.2-\text { Mineralogy and LOI }}$}

The LOI results (Figure 14) showed a general increase in shell and organic matter toward the northern part of the study area. This trend was observed from the southernmost site (3S) through to the northernmost site $(4 \mathrm{~N})$ but was somewhat interrupted at Sites 0 and $1 \mathrm{~N}$ (between 35.38 and 35.40 degrees latitude), where the overall increasing trend became flatter. Sites 0 and $1 \mathrm{~N}$ also differ from the other sites in that they show a slightly higher amount of organic carbon compared to inorganic carbon (the opposite is true at the other sites). These results tentatively suggest two possibilities regarding dredging impacts: 1) the dredge event could have impacted certain biota, and 2) soft-bodied biota were less impacted than shelled/hard bodied biota.

Additional data is needed to address these possibilities - it is unclear if Sites 0 and $1 \mathrm{~N}$ naturally differ from the other sites_-but viewing these results in context of the grainsize and stratigraphy results suggests it is unlikely that the flatter trend and predominance of organic carbon at Sites 0 and $1 \mathrm{~N}$ is a result of the dredging operation. The dredge facies was not observed among the grainsize nor the stratigraphic data anywhere in the field area (see Sections 6.1 \& 6.3), suggesting that its impact on the study area was negligible. It is worth noting also that the longshore currents in the area are not conducive to moving material north of Site 0 , meaning that dredge material would not reach Site $1 \mathrm{~N}$.

While the significance of the LOI data in connection to impacts from dredging is unclear, the data do seem to suggest that biota prefer smaller grainsizes. The increasing abundance of biota toward the north shown in the LOI data appears correlated to the 
overall decrease in grainsize toward the north shown in the spatial grainsize data (Figure 12). This could suggest a preference—especially among shelled biota—of the weakerenergy environment in the north indicated by smaller median grainsizes.

\section{$\underline{6.3-\text { Stratigraphy }}$}

Interpretations of the stacking patterns suggest that, with the exception of SP V, they were indicative of a 'normal' beach environment and did not show signs of being impacted by the dredge material. The interpretations of each SP are described in detail below.

Stacking Pattern I (Figure 17a) was found throughout the year and at every site. As a massive sand layer, it is indicative of an environment of rapid deposition. Spatially, SP I was most commonly found at the oceanward location of the transect, which was located in the swash zone (Figure 17b). This section of each transect experienced the most wave action and would be heavily influenced by tides, further indicating that SP I is indicative of a rapid-deposition environment.

Stacking Pattern II (Figure 15b) was the only other SP that was found throughout the year. The laminae of coarser sands likely indicate a lag deposit, perhaps formed as the tide ebbed. The laminae of coarser sands suggest a weakening energy pattern no longer able to entrain its load. The thicker beds of finer sands suggest deposition over the laminae as the tide flowed, with the process repeating with the next outgoing tide. Stacking Pattern II was most commonly found at the oceanward location, which suggests a correlation with wave-driven processes (Figure 16b).

Stacking Patterns III, IV, V, and VI were only rarely found throughout the course of the study. With the exception of SP IV, they were observed exclusively at the duneward location and were not observed at the southern Sites (Figure 16), indicating probable riverine influence on the northern strata. Aerial imagery from GoogleEarth 
(1994-2018) show episodes of localized riverine breaches onto the northern beaches-particularly at Site $1 \mathrm{~N}$ - highlighting, again, a key difference between the northern and southern beaches: the northern coast has a proximal eastward terrigenous connection, whereas the southern beach is a spit that is lagoonally-severed from any real riverine connections. The dark black laminae observed in SP III is indicative of this type of riverine deposit; data collected during the study showed that SP III was absent from the southern Sites, which originally led us to hypothesize that the dark grains of SP III were deposited on the beach via the watershed since no streams exist on the sandspit along which the southern Sites are located.

It is unclear why SP III was not observed in the summer. If the dark grains are sourced by the watershed, it is possible that they are not supplied to the beach during California's extensive dry season, which was well underway when stratigraphy was described in Summer 2018. The rainy season in California begins approximately in October, so there would have been time for the dark grains that were observed during Fall 2017 (in November, specifically) to be transported by storm runoff to the beaches from the watershed.

Stacking Pattern IV (Figure 15b) was only observed during Fall 2017 and Spring 2018; unlike the other less common SPs, it was observed in the north as well as the south. Stacking Pattern IV is indicative of the shallow burial of ripple marks and was found at both the duneward and oceanward locations. The buried ripple marks indicate a period of sediment transport followed by deposition. SP IV likely formed as tidal action moved sediments back and forth before additional sediments were deposited on top-either by weakening waves or wind currents. This interpretation is supported by the observation surface ripples at the duneward and oceanward sections of several transects.

Stacking Pattern VI (Figure 15c) was observed during Spring 2018 and Summer 2018 and only at Site 2N. It is likely another example of a lag deposit, albeit one 
indicative of a higher-energy depositional environment than that indicated by SP II, since higher-energy waves would be needed to entrain the gravels and pebbles observed in the stratigraphy. Its relegation to one site is puzzling because a higher-than-normal energy event such as a storm would be expected to influence additional sites. Therefore, there is likely some unique factor about Site $2 \mathrm{~N}$ that accounts for SP VI; however, additional research is needed to understand what that factor may be.

Stacking patterns I, II, III, IV, and VI indicate a natural beach system. Stacking Patterns I, IV, and VI are similar to stratigraphy described by Dingler et al. (1982). Each of these SPs are consistent with expected beach deposits (Woodroffe, 2002). However, SP V (Figure 15c) was defined by the presence of the Dark Stratum, which we interpret to be remnant dredge material. Stacking Pattern V was observed during each season except Summer 2018 and was only found at Site 0. The following subsection discusses our interpretation of the Dark Stratum as remnant dredge material.

\subsection{1 - Dark Stratum as Dredge Material}

The nature of the Dark Stratum was initially unclear. The sediments that composed the Dark Stratum were visually similar to the dredge material at the time of deposition (Figure 2). However, initial grainsize results indicated that the Dark Stratum sediments had a median grainsize of $193 \mu \mathrm{m}$ whereas the Harbor Sample (dredge proxy) had a median grainsize of $163 \mu \mathrm{m}$ (Figure 8). Each of these samples had median grainsizes that were smaller than those of the surficial sediments at Site 0 (Figure 8), yet their difference from each other initially suggested that they were two distinct facies. After taking into account the role of littoral drift, however, we started to see that the Dark Stratum and Harbor Sample could each be representative of the same dredge facies.

Recall from Section 2.3.2 that the littoral cutoff diameter (LCD) can be used to predict the proportion of sediment that will be removed from the littoral system and 
deposited offshore. Limber et al. (2008) noted that there are several methods that have been used to calculate the LCD, but Best \& Griggs' (1991) has been used most often. Best \& Griggs' (1991) method assumes that as much material as possible remains on the beach. Their method is useful for calculating the minimum amount of sediment that will be removed from the beach, which allows for a 'worst case' assumption to be made in terms of the longevity of the dredge material at the dumpsite (i.e., the least amount of dredge possible will be removed from the dumpsite, meaning it will take more time to remove it naturally). Using their method (see Section 4.5), the LCD for Site 0 was calculated to be $150 \mu \mathrm{m}$. Comparing this LCD value to the grainsize profile for the Harbor Sample (Figure 19), it is clear that approximately $35-40 \%$ of the sample falls below the LCD threshold. Therefore, 35 - $40 \%$ of the dredge material would have been removed from the littoral system entirely and deposited offshore (Limber et al., 2008).

Assuming the removal of the finer component of the Harbor Sample, the grainsize curves in Figure 19 can be renormalized to show the profile of the predicted remnant component (remnant dredge). The renormalized grainsize curves (Figure 20) show that the Harbor Sample and Dark Stratum profiles are nearly identical. This suggests that the Dark Stratum could indeed be remnant dredge material, and that the component of the dredge material below the LCD was likely removed from Site 0.

If the Dark Stratum and Harbor Sample are representative of the same facies, one would expect the mineralogy of each to be similar. This was not the case. The Dark Stratum and Harbor Sample had distinct QIL abundances from each other (Figure 13). The mineralogic data do not completely dispute the interpretation of the Dark Stratum as remnant dredge, but more work is needed to better understand the result - understanding how different mineral grains might be sorted out by littoral drift would help further elucidate these findings. 


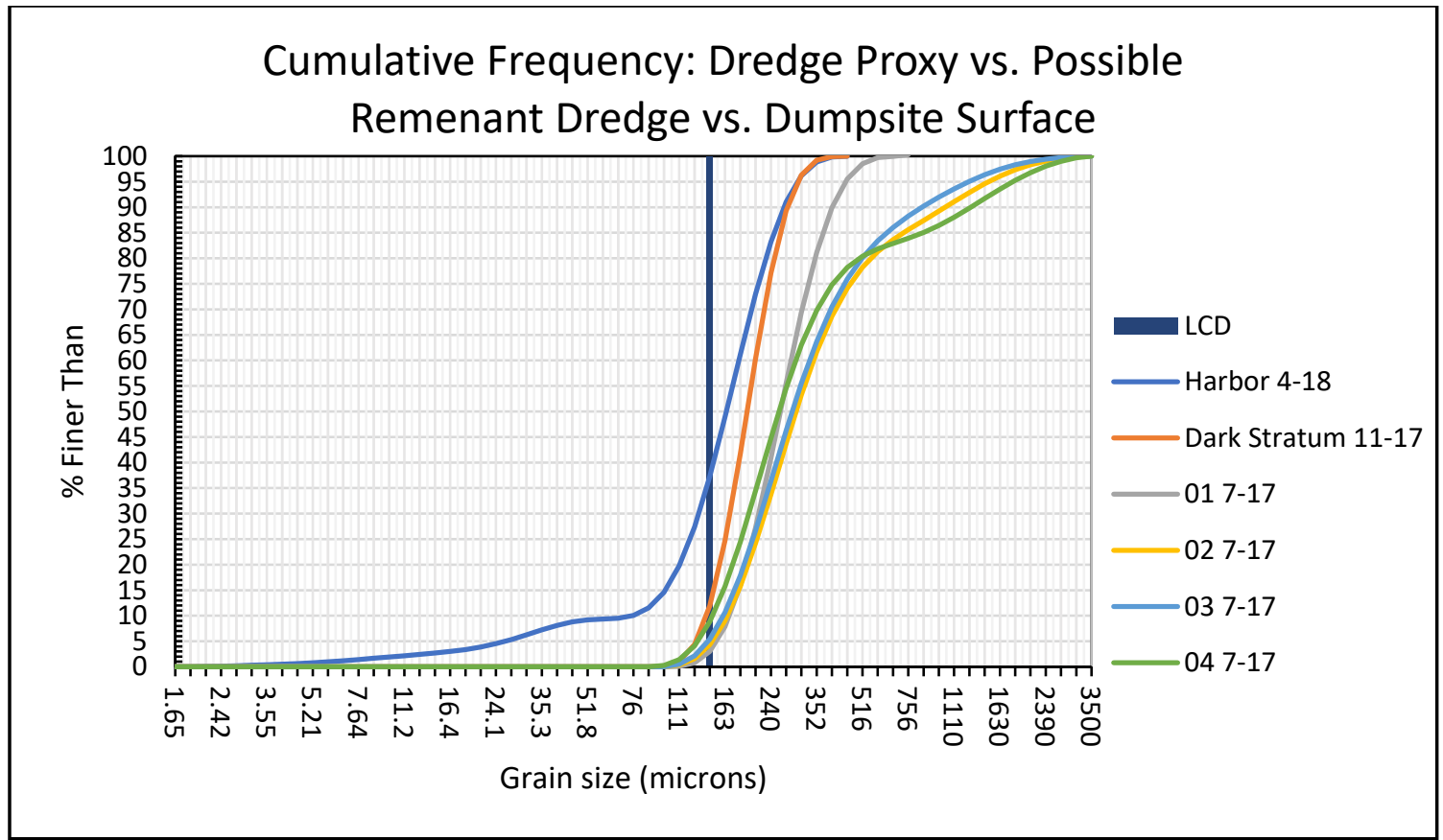

Figure 19: Cumulative frequency plot in Figure 9 with the LCD shown at $150 \mu \mathrm{m}$. Approximately 35-40\% of the Harbor Sample falls below the LCD, suggesting much of the dredge material would be taken out of the littoral system and deposited offshore. The remaining $60-65 \%$ would remain in the littoral system and presumably be transported via longshore currents back to the entrance channel within Morro Bay Harbor.

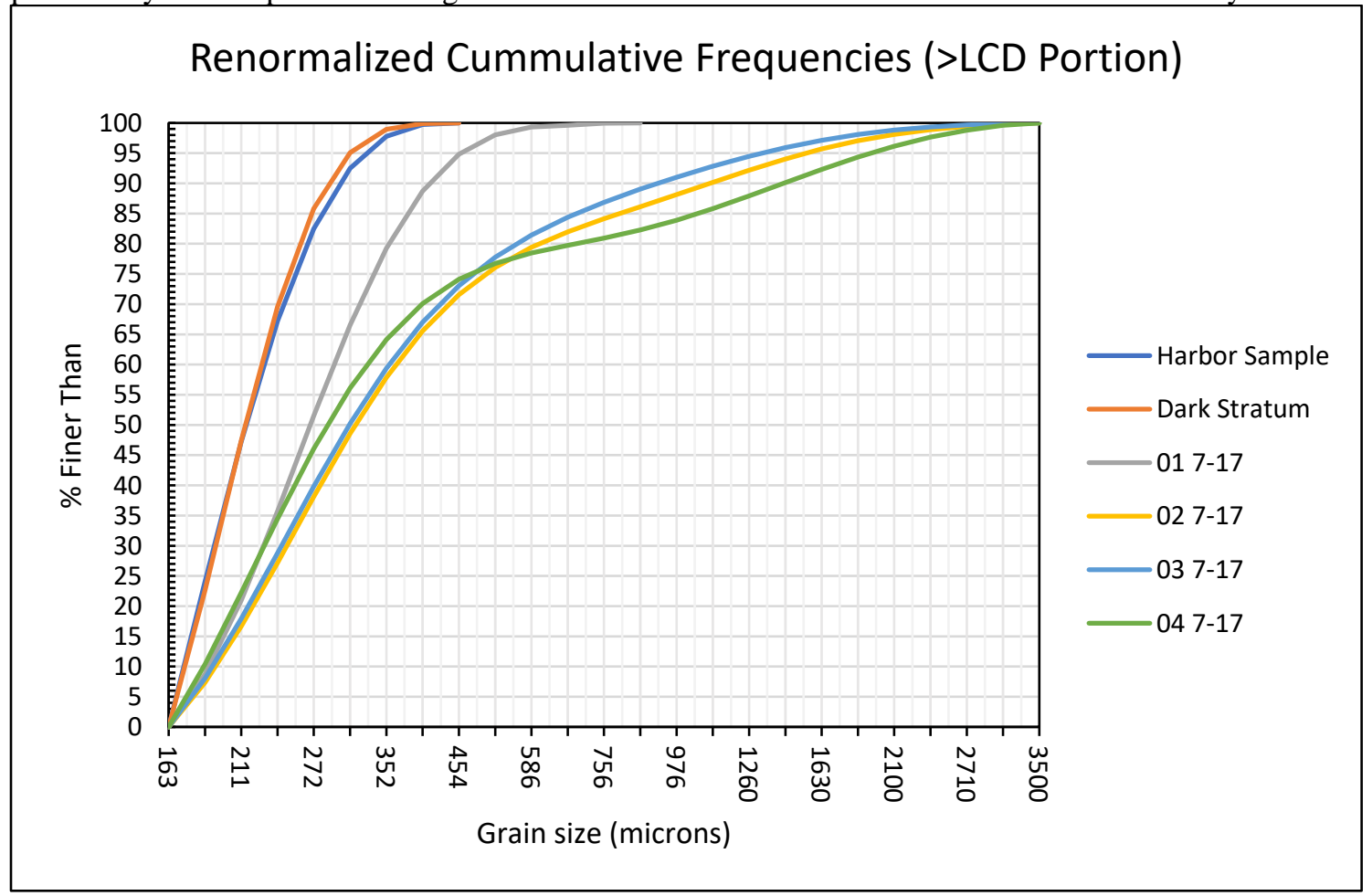

Figure 20: Renormalized cumulative frequency plots of the grainsize samples shown in Figures 8 and 19. The curves have been renormalized to show the portion of each sample that would remain within the littoral system after accounting for the LCD. The renormalized curves for the Harbor Sample and Dark Stratum are nearly identical, indicating that the Dark Stratum is remnant dredge material. 

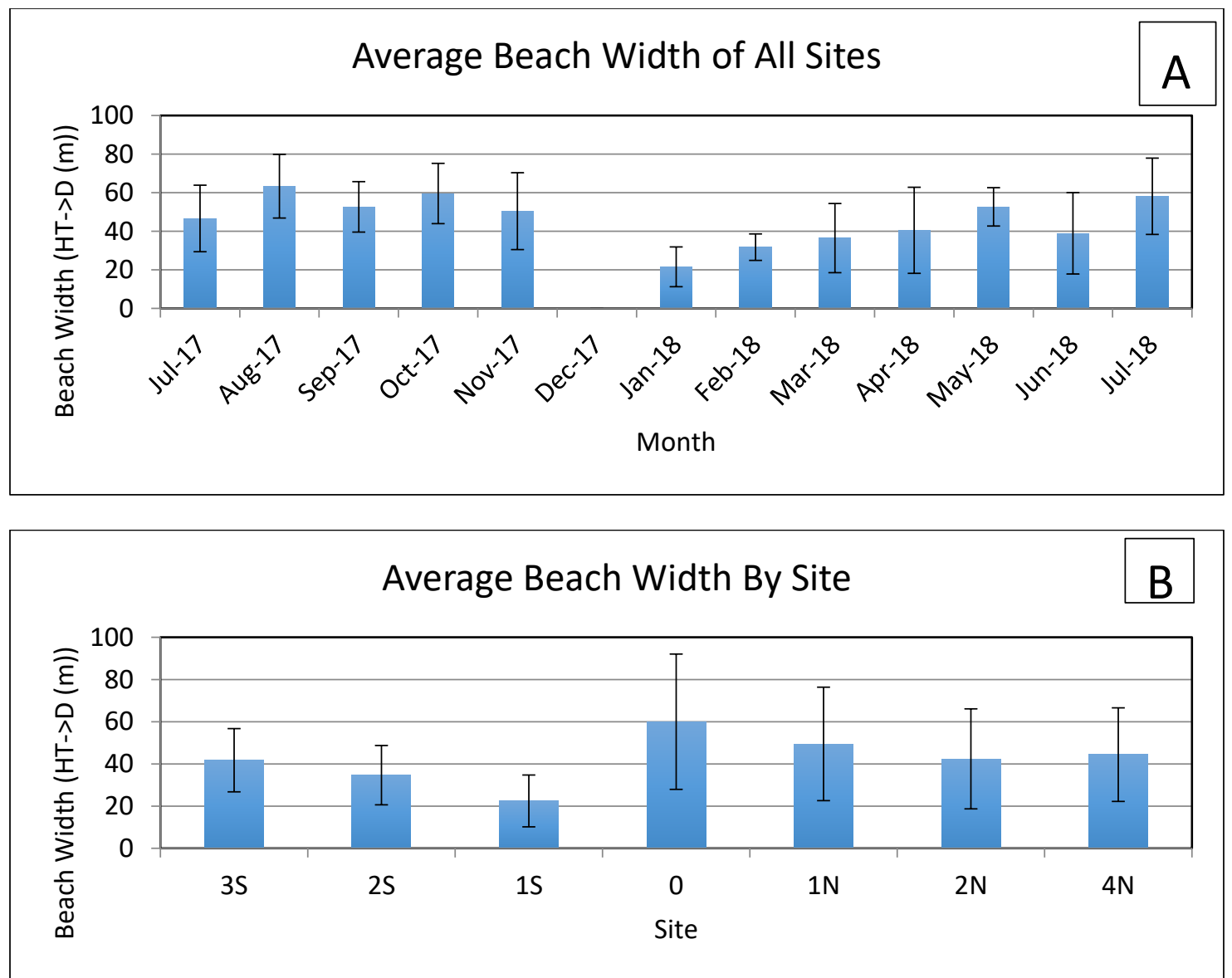

Figure 21: Average beach widths over time (A) and space (B). Beach width was measured from the dunes to the high tide line at each site. Graph A shows averaged widths for all sites for a given month; Graph B shows averaged widths for all months for a given site. Graph A shows an expected narrowing trend in the winter and widening trend in the summer. Graph B shows that Site 0 , the dumpsite, maintained the widest profile width throughout the study period, suggesting that the dredge sediment was successful in protecting the dumpsite from erosion.

\section{$\underline{6.4 \text { - Persistence of Dredge Material at Site } 0}$}

Stacking Pattern V, which contained remnant dredge material, persisted for approximately one year before becoming undetectable sometime between April and July 2018. The fate of this material after it was no longer observed in the summer stratigraphy is currently unknown, but encompasses the possibilities of being buried deeper, being mixed and homogenized with the in-situ sediment, or removed completely and dispersed at another location. The most likely fate is deeper burial as sediment was transported shoreward during the beach's transition from its winter to summer profile. The 
persistence of the dredge material indicates that it fulfilled its role as beach nourishment in protecting Site 0 from erosion. Looking at beach profile data appears to confirm this. Temporally, beach profile data show an expected trend in that profile widths decrease (increase) in the winter (summer) (Figure 21a). Spatially, profile data indicate that Site 0 was the widest of all the sampling locations, suggesting that the persistence of the dredge material could promote the area to maintain a wider beach throughout the study period and perhaps from previous dredging (Figure 21b). Dredge operations occur about every decade since $\sim 1950$, so several dredging operations have occurred. Over time, these operations could anthropogenically keep the area around Site 0 wider than it would be naturally. To date, however, it remains unclear exactly what the dredge is doing to the beachform - whether it is nourishing the beach and helping keep pace with changes in climate and sea-level (Figure 1)--as GoogleEarth imagery dating back through 1994 shows Site 0 as typically being the widest of all the sites: Site 0 extends on average coastwards $\sim 100 \mathrm{~m}$ beyond the site marker, which is consistently $30-70 \mathrm{~m}$ longer than coastal extensions from other site markers (June-September since 1994). A map of the area from 1897 (USGS, Cayucos Quadrangle) shows a similar beach-width to today ( $\sim 0.9 \mathrm{~km}$ from the cross section of Cabrillo Hwy and Atascadero Rd), making it possible that the dredge is playing a role in sustaining this northern beachform.

\section{$\underline{6.5-\text { Differences Between the Northern and }}$ $\underline{\text { Southern Beaches }}$}

Our data show that the northern and southern beaches in the study area differ from each other in several ways. Figures $10,11, \& 12$ show key differences in median grainsize which suggest environments with different energy level conditions. The south appears to be impacted by stronger waves overall and is more subject to large-scale changes in the surficial environment (e.g., millimeter-scale differences in median grainsize). The apparent higher energy in the south also likely explains the less-varied 
stratigraphy shown in Figure 16, since the more powerful waves would rework he sediment more often.

Using the LCD as a proxy for wave energy in the north and south also points to overall stronger wave conditions in the south. Using the method detailed in Section 4.5, the LCD for the northern and southern beaches was calculated to be $142 \mu \mathrm{m}$ and $158 \mu \mathrm{m}$, respectively. Assuming stronger waves can be correlated to a higher LCD, this data support the south being exposed to higher wave energy compared to the north.

Our current understanding of the littoral drift mechanism in the area suggests that dredge material would not be transported north of the dumpsite by littoral currents (Figure 4). This idea appears to be supported by the beach profile data presented in Figure 21, wherein Site 0 is wider than the next-widest site by approximately $10 \mathrm{~m}$. Satellite photos of the study area extending decades into the past consistently show a northwesterly wave approach in the north, which strengthens the idea that littoral drift would not transport dredge material north of Site 0 .

\section{$\underline{6.6-B i o l o g y}$}

In this section, the species diversity and LOI data presented in the Results are compared to mean median grainsize results on the same spatial scales. Overall, finer median grainsizes in the north appear correlated to higher biodiversity and organic matter (Figure 22, 14b). In terms of species diversity, bird species appear more strongly correlated to grainsize than invertebrates do $\left(\mathrm{R}^{2}=0.9419\right.$; Figure 22a). However, the LOI data, which account for both shelled and soft-bodied organisms, show a higher percent abundance of organic matter in the north versus the south (Figure 14b). The LOI data also show a slightly different trend in the organic matter abundance at Site 0 and $1 \mathrm{~N}$ versus the other northern sites, indicating a possible dredge impact. However, further work is needed to fully understand what such an impact might be. 

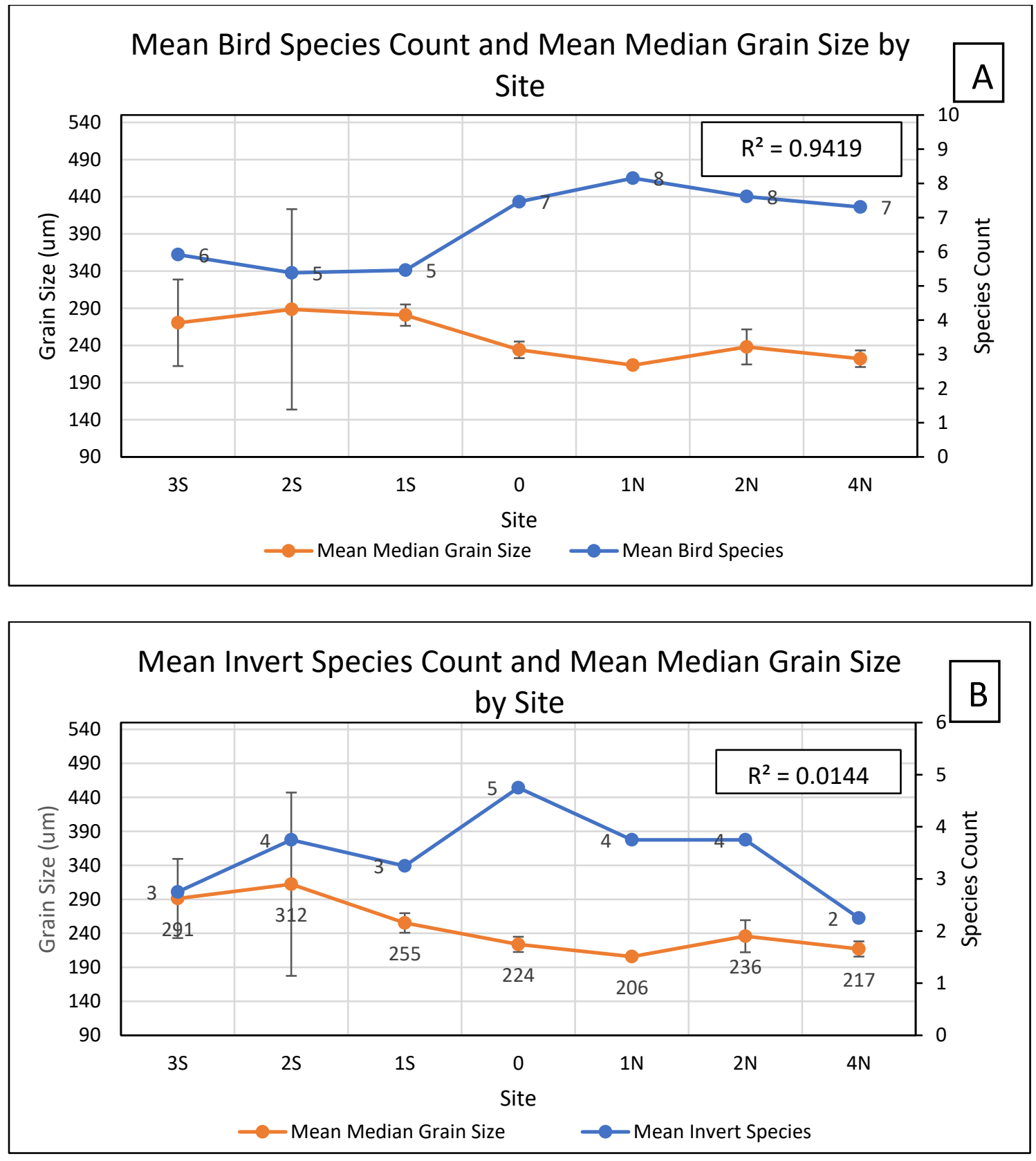

Figure 22: Mean bird species count (a) and mean invert species count (b) by Site. One standard deviation is shown for mean median grain size. $\mathrm{R}^{2}$ values were obtained by plotting mean species count and mean median grain size against each other for both graphs. Bird species diversity was strongly correlated to grain size and showed a pronounced increase among the northern Sites and Site 0. Invert species diversity was not correlated to grain size. Invert species diversity increased slightly at Site 0 but was mostly consistent throughout the study area. 
Considering that birds feed on invertebrate species, the stronger presence of both in the north makes sense. However, a possible alternate explanation for this trend is the higher amount of human activity at the northern sites and Site 0 (Joshua Reese, personal communication, November 11, 2017). More human activity means more sources for food, so birds may be attracted to the northern part of the field area due to the higher density of restaurants, picnics, and campsites.

\section{$\underline{6.7-\text { Evaluation of Hypotheses }}$}

The results confirm the null hypothesis - the dredging operation had no discernible impacts on the study area. However, the reason this hypothesis is confirmed is not because all of the other hypotheses were disproven, but rather because their outcomes were not as harmful as initially predicted.

Hypothesis 1A stated that "the dredged sediments will be sedimentologically different from the sand at Morro Strand State Beach and Montaña De Oro State Beach." This was ultimately confirmed - the Harbor Sample, which acted as a proxy for the dredged sediment, had a completely different grainsize profile than any of the surficial sediment observed throughout the rest of the study area. Its mineralogy was also unique. However, the littoral system demonstrated a remarkable ability to accommodate changes in median grainsize, likely diminishing the impact of dumping this material onto Morro Strand State Beach.

Hypothesis 1B stated that "there will be an abrupt change in stratigraphy at the dumpsite, indicating a significant change in the depositional environment." This was confirmed by the presence of the Dark Stratum (remnant dredge) at Site 0. The dredge material was preserved within the stratigraphy for approximately one year and appeared to allow Site 0 to retain a wider beach profile than the other sampling sites. 
Hypothesis 1C stated that, "The dredged sediments will remain localized at the dumpsite, indicating that changes to the environment are happening in a relatively small area." This hypothesis was only partially confirmed. Remnant dredge material was only detected at Site 0 , but we were unable to confirm whether or not it was present at other sampling sites. A better understanding of sediment movement in the area is neededbroader mechanisms are well-understood, but higher-resolution data is needed to understand how sediments are moved at smaller temporal-spatial scales.

\section{$\underline{6.8-\text { Gaps in Knowledge Addressed }}$}

We began this study with three objectives: 1) to understand how changes to sedimentology and stratigraphy may themselves change important characteristics of the beach environment or mitigate potential dredging impacts; 2) to assess these impacts at a higher-resolution spatial-temporal scale than currently exists in the literature; and 3) to compare biodiversity to grainsize over an extended period to understand how introducing new material to an environment may affect coastal bird and invertebrate species. Each of these objectives were designed to address gaps in our knowledge of dredging impacts. The following will address how these objectives were met.

In meeting our first objective, we showed that changes in sedimentology and stratigraphy were unlikely to impact the beach environment long-term. The oscillation in median grainsize over the course of the study indicated an environment in constant flux as the beach profile adjusted towards equilibrium. Similarly, the stratigraphic data did not show any unexpected stacking patterns (though remnant dredge material was found within SP V). Our work has provided a more comprehensive understanding of how beach nourishment impacts an onshore dumpsite by examining sedimentology and stratigraphy.

In meeting our second objective, we provided a high-resolution spatial-temporal context for the observed changes in sedimentology and stratigraphy. We showed that 
large-scale changes in median grainsize (e.g., $500 \mathrm{um}$ ) could be mitigated within weeks to months. Stratigraphy changed on a scale of at least months. We also saw spatial differences that persisted through time, such as an overall coarser mean median grainsize among the southern sites. Our work has broadened our understanding of how beach nourishment impacts an onshore dumpsite by examining changes over space and time. In meeting our third objective, we supplemented work by Jaramillo et al. (1993) by showing a correlation between finer sediment and increased biodiversity and organic matter. Our work has increased our understanding of how dredge material impacts an onshore dumpsite by providing a spatial examination of changes to biodiversity and organic matter as they relate to grainsize. 


\section{7 - CONCLUSIONS}

The dredging operation carried out in February 2017 did not have a discernible deleterious impact on the dumpsite nor the surrounding area, confirming the null hypothesis. Overall, the study area appeared to be in a constant state of flux as the beaches evolved toward new equilibria in response to changing conditions. Grainsize data support this idea in showing robust changes in surficial median grainsize occur over the span of weeks to months. Median grainsize data also show that the dredged sediments are part of a unique facies with a median grainsize that is much finer than any surficial material observed within the study area. Stratigraphy data also showed that the environment was constantly reworked, with Stacking Patterns appearing and disappearing each season. Stratigraphy data also showed that, despite the flux observed throughout the study, the dredge material was preserved at the dumpsite for approximately one year, suggesting that it served its intended purpose as nourishment material. Applying the concept of the LCD allows us to predict that approximately $35-40 \%$ of the dredge material was removed from the littoral system, but the ultimate fate of the remnant dredge is unknown. Biology data showed a possible correlation between finer sediments and increased biologic activity. 


\section{REFERENCES}




\section{REFERENCES}

Barnard, P. L., Foxgrover, A. C., Elias, E. P. L., Erikson, L. H., Hein, J. R., Mcgann, M., Woodrow, D. L. (2013). Integration of bed characteristics, geochemical tracers, current measurements, and numerical modeling for assessing the provenance of beach sand in the San Francisco Bay Coastal System. Marine Geology, 345, 181206. https://doi.org/10.1016/j.margeo.2013.08.007

Best, T., \& Griggs, G. (1991). A sediment budget for the Santa Cruz littoral cell, California. SEPM, 46, 35-50.

Bishop, M. J., Peterson, C. H., Summerson, H. C., Lenihan, H. S., \& Grabowski, J. H. (2006). Deposition and Long-Shore Transport of Dredge Spoils to Nourish Beaches: Impacts on Benthic Infauna of an Ebb-Tidal Delta. Journal of Coastal Research. https://doi.org/10.2112/03-0136.1

Brazeiro, A., \& Defeo, O. (1996). Macroinfauna Zonation in Microtidal Sandy Beaches: is it Possible to Identify Patterns in Such Variable Environments? Estuarine, Coastal and Shelf Science (Vol. 42).

Bruun, P. (1954). Coast erosion and the development of beach profiles (Vol. 44). US Beach Erosion Board.

Chamber of Commerce, Morro Bay. (2017). About the Area. Retrieved from: http://morrochamber.org/page/about_the_area.

California's Fourth Climate Change Assessment. (2019). Statewide Summary Report.

Cousineau, L. A. (2012). Stratigraphy of Quaternary dunes by sand mineralogy and pedogenic features, Los Osos, California. California Polytechnic State University, San Luis Obispo.

Davidson-Arnott, R., 2005. Beach and Nearshore Instrumentation, in Encyclopedia of Coastal Science, ed. by M. Schwartz. Dordrecht, The Netherlands: Springer.

De Jonge, V. N., Schuttelaars, H. M., van Beusekom, J. E. E., Talke, S. A., \& de Swart, H. E. (2014). The influence of channel deepening on estuarine turbidity levels and dynamics, as exemplified by the Ems estuary. Estuarine, Coastal and Shelf Science, 139, 46-59. https://doi.org/10.1016/j.ecss.2013.12.030

de Vries, S., Arens, S. M., de Schipper, M. A., \& Ranasinghe, R. (2014). Aeolian sediment transport on a beach with a varying sediment supply. Aeolian Research, 15, 235-244. https://doi.org/10.1016/j.aeolia.2014.08.001

Dean, R. (1988). Managing Sand and Preserving Shorelines. Oceanus, 31(3), 49-55. 
Dean, R. (1991). Equilibrium Beach Profiles: Characteristics and Applications. Journal of Coastal Research, 7(71), 53-84.

Dean, R. \& Charles, L. (1994). Equilibrium beach profiles: concepts and evaluation. Department of Coastal and Oceanographic Engineering, University of Florida.

Demir, H., Otay, E. N., Work, P. A., \& Borekci, O. S. (2004). Impacts of dredging on shoreline change. Journal of Waterway, Port, Coastal and Ocean Engineering, 130(4), 171-178. doi:1061(ASCE)0733-950X(2004)130:4(170)

Devoy, R. J. N., Delaney, C., Carter, R. W. G., \& Jennings, S. C. (1996). Coastal stratigraphies as indicators of environmental changes upon European Atlantic coasts in the late Holocene. Journal of Coastal Research, 564-588.

Diaz-Yourman, GeoPentech, Kinnetic Laboratories. (2014). Final sampling and analysis report: Morro Bay Harbor geotechnical and environmental investigation project sampling, bulk sediment chemistry, geotechnical and suitability determination results.

Dingler, J. R., Anima, R. J., Molzan, D. E., Luepke, G., \& Peterson, C. L. (1982). A field study of littoral processes in Estero Bay, California. Menlo Park.

Dolan, R., Anders, F., and Kimball, S., (1985) Coastal erosion and accretion: U.S. Geological Survey National Atlas, scale 1:7,500,000.

Draft Marketing and Sales Plan. (2016). Discover Morro Bay. Morro Bay.

Du Four, I., \& Van Lancker, V. (2008). Changes of sedimentological patterns and morphological features due to the disposal of dredge spoil and the regeneration after cessation of the disposal activities. Marine Geology, 255, 15-29. https://doi.org/10.1016/j.margeo.2008.04.011

Eittreim, S. L., Xu, J. P., Noble, M., \& Edwards, B. D. (2002). Towards a sediment budget for the Santa Cruz shelf. Marine Geology, 181(1-3), 235-248.

https://doi.org/10.1016/S0025-3227(01)00269-9

Ford, R. (1997). Dynamics of Salt-Marsh Accretion on a Back-Barrier Delta, Morro Bay, California. University of California, Los Angeles.

Fruergaard, M., Andersen, T. J., Johannessen, P. N., Nielsen, L. H., \& Pejrup, M. (2013). Major coastal impact induced by a 1000-year storm event. Scientific Reports, 3(1051), 1-6. https://doi.org/10.1038/srep01051

Gallagher, J. (1996). Late Holocene evolution of the Chorro delta, Morro Bay, California. University of California, Los Angeles. 
Griggs, G. B. (1987). Littoral Cells and Harbor Dredging Along the California Coast. Environ Geol Water Sci, 10(1), 7-20.

Guerra, R., Pasteris, A., \& Ponti, M. (2009). Impacts of maintenance channel dredging in a northern Adriatic coastal lagoon; I, Effects on sediment properties, contamination and toxicity. Estuarine, Coastal and Shelf Science, 85(1), 134-142.

Hagemann, B., White, J., Lott, T., Multari, M., Hoffman, B., Wilson, R., ... Meara, S. (2000). Comprehensive Conservation \& Management Plan for Morro Bay. Morro Bay.

Hapke, C. J., Reid, D., \& Richmond, B. (2009). Rates and Trends of Coastal Change in California and the Regional Behavior of the Beach and Cliff System. Journal of Coastal Research, 25(3), 603-615. https://doi.org/10.2112/08-1006.1

Healy, T. (1994). Channel Dredging, Dredge Spoil Migration and Downdrift. New Zealand Geographer, 50(2), 3-6. https://doi.org/10.1111/j.17457939.1994.tb00411.x

Hicks, D.M., 1985. Sand Dispersion from an Ephemeral Delta on a Wave Dominated Coast. Santa Cruz, California: University of California, Santa Cruz, Ph.D. thesis, $210 \mathrm{pp}$.

Hinkel, J., Nicholls, R. J., Tol, R. S. J., Wang, Z. B., Hamilton, J. M., Boot, G., Klein, R. J. T. (2013). A global analysis of erosion of sandy beaches and sea-level rise: An application of DIVA. Global and Planetary Change, 111, 150-158. https://doi.org/10.1016/j.gloplacha.2013.09.002

Hopskin, C., W. Cai, and X. Hu (2012). Carbon sequestration in wetland dominated coastal systems - a global sink of rapidly diminishing magnitude. Current Opinion in Environmental Sustainability, 4, 186-194.

Howard, P. J. A. (1965). The Carbon-Organic Matter Factor in Various Soil Types. Oikos, 15(2), 229-236.

Hsu, K. J. (1969). Preliminary Report and Geologic Guide to Franciscan Mélanges of the Morro Bay - San Simeon Area, California.

Inman, D., \& Frautschy, J. (1966). Littoral processes and the development of shorelines. In Proceedings Santa Barbara Specialty Conference (pp. 511-536). ASCE.

Jaramillo, E., McLachlan, A., and Coetzee, P. (1993). Intertidal zonation patterns of macroinfauna over a range of exposed sandy beaches in south-central Chile. Mar. Ecol. Prog. Ser. 101: 105-118.

Kraus, N.C., 2005. Beach Profile, in Encyclopedia of Coastal Science, ed. by M. Schwartz. Dordrecht, The Netherlands: Springer. 
Kroon, A., \& Hoekstra, P. (1990). Eolian Sediment Transport on a Natural Beach. Source: Journal of Coastal Research Journal of Coastal Research, 6(6), 367-379.

Krumbein, W. C. (1954). Applications of Statistical Methods to Sedimentary Rocks. Journal of the American Statistical Association, 49(265), 51-66.

Limber, P., Patsch, K., \& Griggs, G. (2008). Coastal sediment budgets and the littoral cutoff diameter; a grain size threshold for quantifying active sediment inputs. Journal of Coastal Research, 24(2), 121-133.

Liu, M., \& Furlong, K. P. (1992). Cenozoic volcanism in the California Coast Ranges: numerical solutions. Journal of Geophysical Research: Solid Earth, 97(B4), 49414951.

Leber, K. M. (1982). Seasonality of macroinvertebrates on a temperate, high wave energy sand beach. Bulletin of Marine Science, 32(1), 86-98.

Macmillan, M. R., Duarte, C., \& Quijón, P. A. (2017). Sandy beaches in a coastline vulnerable to erosion in Atlantic Canada: Macrobenthic community structure in relation to backshore and physical features. Journal of Sea Research, 125: 26-33.

MBEDR (Morro Bay Economic Development Roadmap). (2017). Morro Bay.

MBNEP (Morro Bay National Estuary Program). (2016). State of the Bay 2016. Morro Bay.

MBNEP (Morro Bay National Estuary Program). (2017). State of the Bay 2017. Morro Bay.

Mearns, A., D. Reish, P. Oshida, A. Morrison, M.A. Rempel-Hester, C. Arthur, N. Rutherford, and R. Pryor (2017). Effects of Pollution on Marine Organisms. Water Environment Research, 89(10), 1704-1798.

Moody, L. E., \& Graham, R. C. (1995). Geomorphic and pedogenic evolution in coastal sediments, central California. Geoderma, 67, 181-201. https://doi.org/10.1016/0016-7061(94)00078-O

Moore, L. J., Benumof, B. T., \& Griggs, G. B. (1999). Coastal Erosion Hazards in Coastal Erosion Hazards in Santa Cruz and San Diego Counties, California. Journal of Coastal Research, (S.I. 28), 121-139.

Nairn, R., Johnson, J. A., Hardin, D., Michel, J., Nairnt, R., Johnson, J. A., \& Hardin, D. (2004). A Biological and Physical Monitoring Program to Evaluate Long-term Impacts from Sand Dredging Operations in the United States Outer Continental Shelf. Journal of Coastal Research, 20(20), 126-137. 
Orme, A. (2005). Chapter 16: Morro Bay to Point Conception. In G. Griggs, K. Patsch, \& L. Savoy (Eds.), Living with the Changing California Coast (1st ed., pp. 1-551). University of California Press.

Parkinson, R. W., \& Ogurcak, D. E. (2018). Beach nourishment is not a sustainable strategy to mitigate climate change. Estuarine, Coastal and Shelf Science, 212, 203-209. https://doi.org/10.1016/j.ecss.2018.07.011

Patsch, K., \& Griggs, G. (2006). Littoral Cells, Sand Budgets, and Beaches: Understanding California's Shoreline.

Peterson, C. H., \& Bishop, M. J. (2005). Assessing the Environmental Impacts of Beach Nourishment. BioScience, 55 (10), 887-896. https:/doi.org/10.1641/00063568(2005)055[0887:ATEIOB]2.0.CO;2

Peterson, C. H., Hickerson, D. H. M., Grissom Johnson, G., Grissom Johnsont, G., Peterson, A., Hickerson, C. H., \& Johnson, D. H. M. (2000). Short-Term Consequences of Nourishment and Bulldozing on the Dominant Large Invertebrates of a Sandy Beach. Journal of Coastal Research, 16(162), 368-378.

Pezzuto, P. R., Resgalla, C., Abreu, J. G. N., \& Menezes, J. T. (2004). Environmental Impacts of the Nourishment of Balneario Camboriu Beach, SC, Brazil. Journal of Coastal Research, 39(39), 863-868.

Pringle, A. W. (1996). History, geomorphological problems and effect of dredging in Cleveland Bay, Queensland. Australian Geographical Studies, 34(1), 58-80.

Prothero, D. \& Schwab, F. (2014). Sedimentary geology: an introduction to sedimentary rocks and stratigraphy. New York, NY: W. H. Freeman and Company.

Runyan, K., \& Griggs, G. (2002). Contributions from Coastal Cliff Erosion to the Littoral Budget. (M. Coyne \& K. Sterrett, Eds.), California Beach Restoration Study. Sacramento: California Department of Boating and Waterways and State Coastal Conservancy. Retrieved from https://dbw.parks.ca.gov/pages/28702/files/cbrs_ch8_bluffs.pdf

Smith, S. D. A., \& Rule, M. J. (2001). The effects of dredge-spoil dumping on a shallow water soft-sediment community in the Solitary Islands Marine Park, NSW, Australia. Marine Pollution Bulletin, 42(11), 1040-1048. https://doi.org/10.1016/S0025-326X(01)00059-5

Spencer, T. M. Schuerch, R. Nicholls, J. Hinkel, D. Lincke, A.T. Vafeidis, R. Reef, L. McFadden, S. Brown (2016). Global coastal wetland change under sea-level rise and related stresses: The DIVA Wetland Change Model. Global and Planetary Change, 139, 15-30. 
Tamura, T., Kodama, Y., Bateman, M. D., Saitoh, Y., Watanabe, K., Matsumoto, D., \&amp; Yamaguchi, N. (2011). Coastal barrier dune construction during sea-level highstands in MIS 3 and 5a on Tottori coast-line, Japan. Palaeogeography, Palaeoclimatology, Palaeoecology, 308(3-4), 492-501.

USACE (United States Army Corps of Engineers). (1973). Draft environmental statement operation and maintenance of Morro Bay Harbor, San Luis Obispo County, California

USACE (United States Army Corps of Engineers). (2016). Final supplemental environmental assessment for Morro Bay six year federal maintenance dredging program San Luis Obispo County, California.

USACE (United States Army Corps of Engineers), SLOCOG (San Luis Obispo Council of Governments), Everest (Everest International Consultants, I., Merkel \& Associates, I., \& King, P. (2016). San Luis Obispo County Coastal Regional Sediment Management Plan.

USGS (United States Geological Survey). Cayucos Quadrangle [map]. USGS, 1897.

van Maren, D. S., van Kessel, T., Cronin, K., \& Sittoni, L. (2015). The impact of channel deepening and dredging on estuarine sediment concentration. Continental Shelf Research, 95, 1-14. https://doi.org/10.1016/j.csr.2014.12.010

Vorosmarty, J., B McIntyre, P. Gessner. (2010). Global Threats to Human Water Security and River Biodiversity. Nature. 468. 334. 10.1038/nature09549.

Wienberg, C., \& Hebbeln, D. (2005). Impact of dumped sediments on subaqueous dunes, outer Weser Estuary, German Bight, southeastern North Sea. Geo-Marine Letters, 25, 43-53. https://doi.org/10.1007/s00367-004-0202-1

Woodroffe, C. D. (2003). Coasts: form, process, and evolution. New York: Cambridge University Press.

Work, P. A., Fehrenbacher, F., \& Voulgaris, G. (2004). Nearshore Impacts of Dredging for Beach Nourishment. J. Waterway, Port, Coastal, Ocean Eng., 130(6), 303-311. https://doi.org/10.1061/(ASCE)0733-950X(2004)130:6(303)

Yancey, T. E., \& Lee, J. W. (1972). Major Heavy Mineral Assemblages and Heavy Mineral Provinces of the Central California Coast Region. Geological Society of America Bulletin, 83(7), 2099-2104.

Yates, M. L., Guza, R. T., \& O'reilly, W. C. (2009a). Equilibrium shoreline response: Observations and modeling. J. Geophys. Res, 114, 9014.

https://doi.org/10.1029/2009JC005359 
Yates, M. L., Guza, R. T., O’Reilly, W. C., \& Seymour, R. J. (2009b). Seasonal persistence of a small southern California beach fill. Coastal Engineering, 56, 559564. https://doi.org/10.1016/j.coastaleng.2008.11.004 
APPENDICES 
APPENDIX A: LITTORAL CELL TERRESTRIAL SEDIMENT SOURCES 


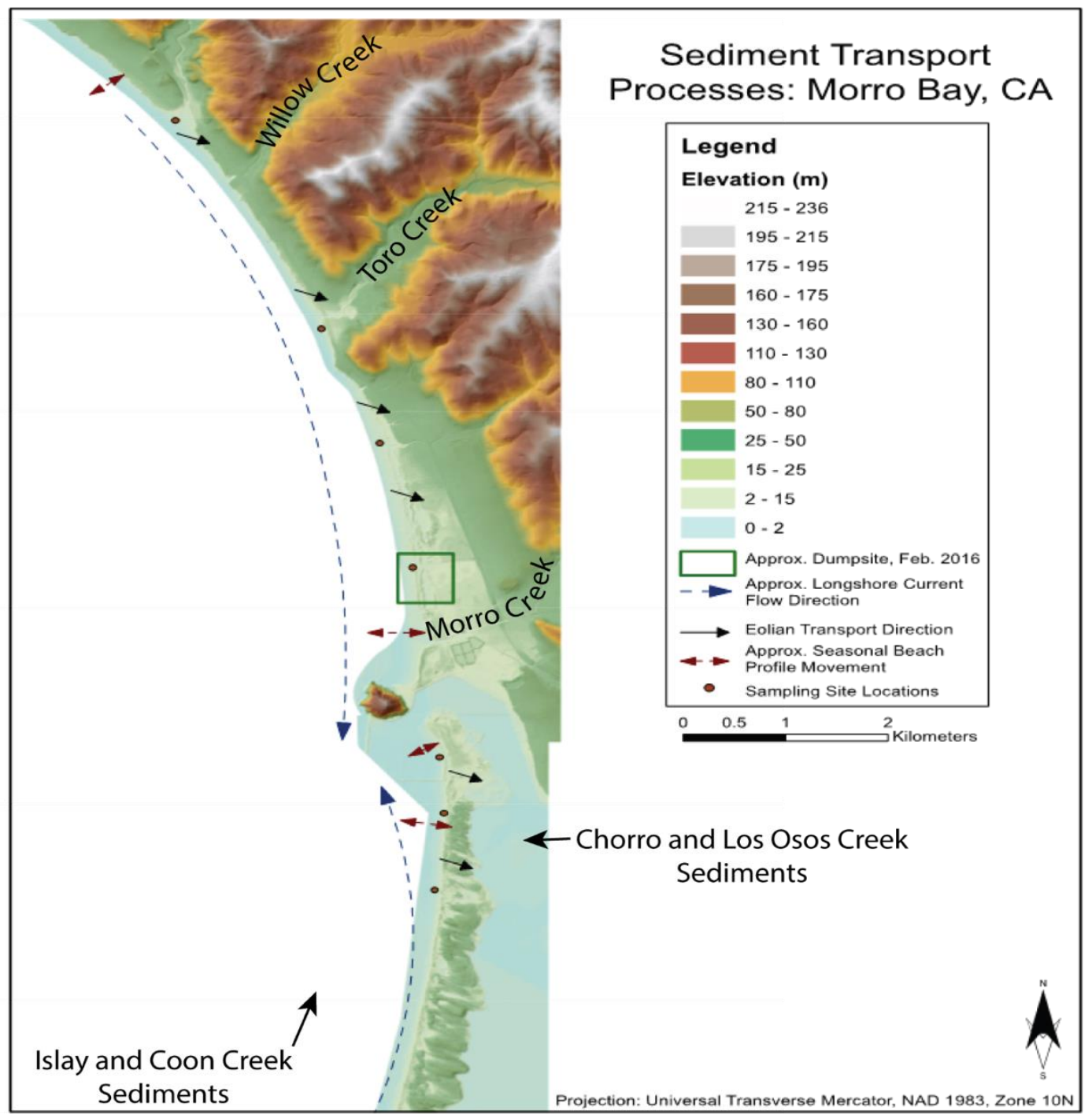

Figure A1: Main terrestrial sources of sediment available for littoral cell transport along the beach. Stream discharges ranged from 0.25 (summer) to 1.25 (spring) cfs during a regional flow assessment by Stillwater Sciences in 2014, with minimal flows capable of transporting grain sizes between 1-500 $\mu \mathrm{m}$. During high flow, stream velocity may transport grains up to $\sim 1800 \mu \mathrm{m}$ to the beach system (see Appendix B for an explanation of how stream discharge was used to estimate incoming grain sizes). 
APPENDIX B: RANGE OF GRAINSIZES AVAILABLE TO LOCAL CREEKS 


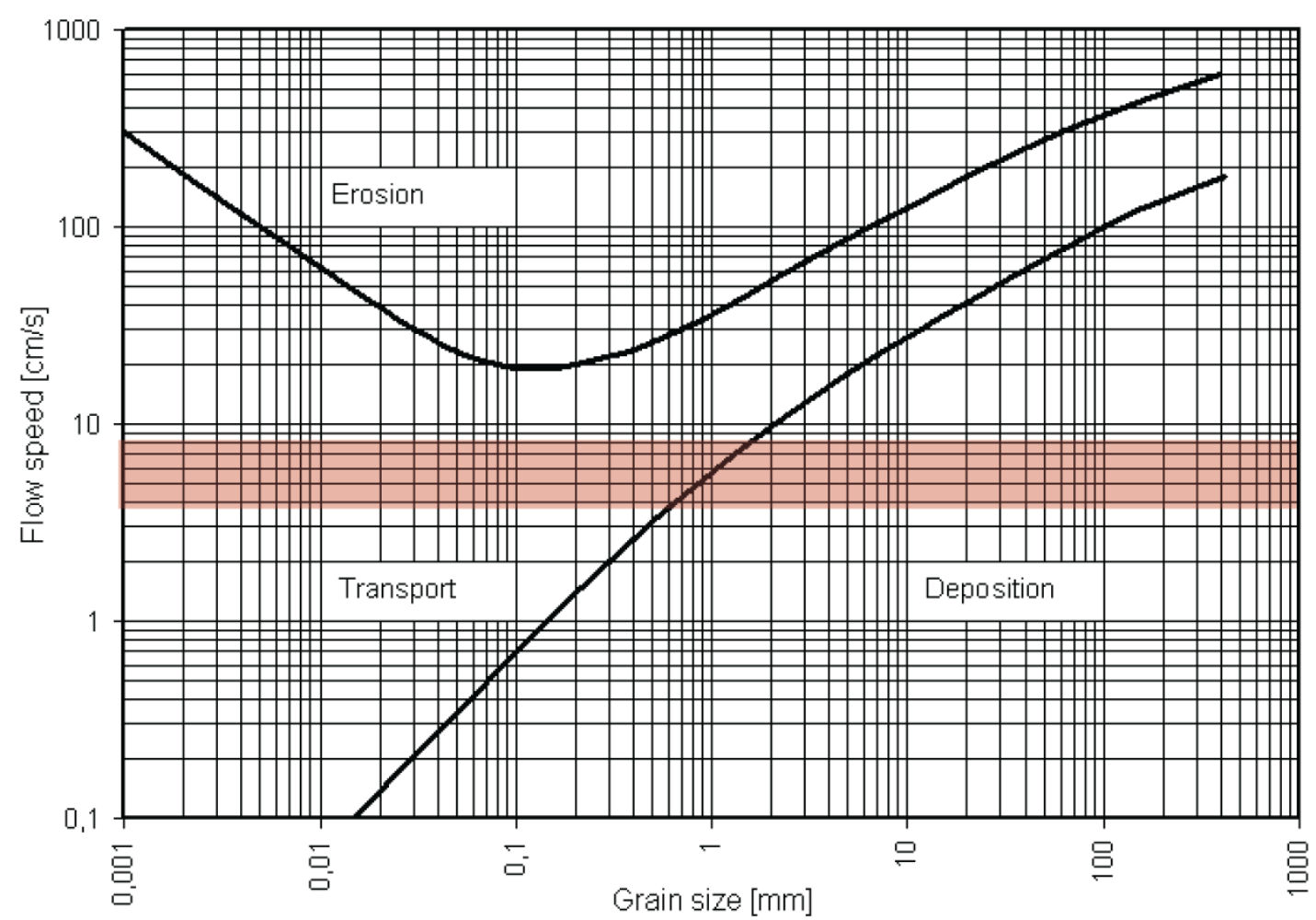

Figure B1: The Hjulstrom Curve used to estimate the range of grain sizes provided by creeks to the beaches of Morro Bay (see Appendix A). Using depths reported in the 2014 flow assessment ( 15-1.5' depth) and stream widths from GoogleEarth (2-3' widths), the summer and spring discharges (0.25-1.25 cfs) relate to flow speeds ranging from $\sim 0.1-0.3 \mathrm{f} / \mathrm{s}$ ( or $\sim 4-8.5 \mathrm{~cm} / \mathrm{s}$ ). Shading this flow speed area red on the Hjulstrom Curve shows grain sizes undergoing transportation and/or deposition. 
APPENDIX C: STRATIGRAPHIC DESCRIPTIONS 


\begin{tabular}{|c|c|c|c|c|c|}
\hline Season & Site & Pit & Depth & Description & $\begin{array}{l}\text { Stacking } \\
\text { Pattern }\end{array}$ \\
\hline \multirow[t]{16}{*}{$\begin{array}{l}\text { Fall } \\
2017\end{array}$} & \multirow[t]{2}{*}{$3 \mathrm{~S}$} & 1 & $0-30 \mathrm{~cm}$ & $\begin{array}{l}\text { fine sand, rounded, well-sorted, } \mathrm{QFL}=90 / 5 / 5 \text {, no } \\
\text { shell fragments. }\end{array}$ & I \\
\hline & & 4 & $0-30 \mathrm{~cm}$ & $\begin{array}{l}\text { fine to medium sand, sub-rounded, well-sorted, QFL } \\
=75 / 15 / 10, \text { no shell fragments. }\end{array}$ & I \\
\hline & \multirow[t]{4}{*}{$2 \mathrm{~S}$} & 1 & $0-30 \mathrm{~cm}$ & $\begin{array}{l}\text { massive, medium sand, sub-rounded, well-sorted, } \\
\text { QFL }=80 / 10 / 10, \text { shell fragments } \sim 10 \%\end{array}$ & I \\
\hline & & \multirow[t]{3}{*}{4} & $0-18 \mathrm{~cm}$ & $\begin{array}{l}\text { Fine to coarse sand, sub-rounded, moderately sorted, } \\
\text { laminated, } Q F L=40 / 40 / 20 \text {, shell fragments } \sim 5 \% \text {. }\end{array}$ & \multirow[t]{3}{*}{ II } \\
\hline & & & $\begin{array}{l}18-23 \\
\mathrm{~cm}\end{array}$ & $\begin{array}{l}\text { fine to very coarse sand, rounded to sub-angular, } \\
\text { poorly sorted, } \mathrm{QFL}=30 / 30 / 40 \text {, shell fragments } \sim 11 \text { - } \\
20 \% \text {. }\end{array}$ & \\
\hline & & & $\begin{array}{l}23-30 \\
\mathrm{~cm}\end{array}$ & $\begin{array}{l}\text { fine to medium sand, sub-rounded, moderately } \\
\text { sorted, } Q F L=25 / 25 / 50, \text { shell fragments } \sim 10 \%\end{array}$ & \\
\hline & \multirow{5}{*}{$1 \mathrm{~S}$} & \multirow[t]{4}{*}{1} & $0-8 \mathrm{~cm}$ & $\begin{array}{l}\text { fine sand, well-rounded, well-sorted, } \mathrm{QFL}= \\
40 / 35 / 25 \text {, shell fragments } \sim 5 \%\end{array}$ & \multirow[t]{4}{*}{ I } \\
\hline & & & $8-10 \mathrm{~cm}$ & $\begin{array}{l}\text { very fine sand, well-rounded, well-sorted, } \mathrm{QFL}= \\
20 / 20 / 60 \text {, shell fragments } \sim 5 \%\end{array}$ & \\
\hline & & & $\begin{array}{l}10-20 \\
\mathrm{~cm}\end{array}$ & $\begin{array}{l}\text { fine sand, rounded, well-sorted, QFL }=40 / 35 / 25 \text {, } \\
\text { shell fragments } \sim 10 \%\end{array}$ & \\
\hline & & & $\begin{array}{l}20-30 \\
\mathrm{~cm}\end{array}$ & $\begin{array}{l}\text { fine sand, rounded, well-sorted, QFL }=30 / 30 / 40, \\
\text { shell fragments } \sim 11-20 \%\end{array}$ & \\
\hline & & 4 & $0-30 \mathrm{~cm}$ & $\begin{array}{l}\text { medium to coarse sand with a medium bed of coarse } \\
\text { to very coarse sand, matrix is sub-rounded, well- } \\
\text { sorted, laminations of dark material, QFL }=50 / 25 / 25 \text {, } \\
\text { shell fragments } \sim 10 \% \text {. Medium bed is sub-angular to } \\
\text { angular, poorly sorted, QFL }=50 / 25 / 25 \text {, shell } \\
\text { fragments } \sim 10 \%\end{array}$ & II \\
\hline & \multirow[t]{3}{*}{0} & 1 & $0-15 \mathrm{~cm}$ & $\begin{array}{l}\text { very fine sand, very dark grey, wavy laminations } \\
\text { throughout, no shells. }\end{array}$ & \multirow[t]{2}{*}{ V } \\
\hline & & & $\begin{array}{l}15-30 \\
\mathrm{~cm}\end{array}$ & $\begin{array}{l}\text { Fine grained sand, well-rounded, well-sorted, } \mathrm{QFL}= \\
70 / 15 / 15 \text {, no shells. }\end{array}$ & \\
\hline & & 4 & $0-30 \mathrm{~cm}$ & $\begin{array}{l}\text { interbedded fine and coarse sand, well-sorted, sub- } \\
\text { rounded, trough cross beds of finer material within a } \\
\text { matrix of coarse sand near the surface. }\end{array}$ & IV \\
\hline & \multirow[t]{2}{*}{$1 \mathrm{~N}$} & 1 & $0-30 \mathrm{~cm}$ & $\begin{array}{l}\text { fine to medium sand with interlaminae of dark } \\
\text { material, rounded to sub-rounded, well-sorted, QFL }= \\
60 / 20 / 20 \text {, shell fragments } \sim 3 \%\end{array}$ & III \\
\hline & & 4 & $0-30 \mathrm{~cm}$ & $\begin{array}{l}\text { very fine to fine sand, sub-rounded, moderately } \\
\text { sorted, hummocky cross beds, laminated, red and } \\
\text { green grains present, } Q F L=70 / 15 / 15 \text {, shell } \\
\text { fragments 3\% }\end{array}$ & IV \\
\hline
\end{tabular}




\begin{tabular}{|c|c|c|c|c|c|}
\hline & $2 \mathrm{~N}$ & 1 & $0-30 \mathrm{~cm}$ & $\begin{array}{l}\text { fine sand with medium bed of medium sand to } \\
\text { cobbles, matrix is well-sorted, QFL }=50 / 40 / 10 \text {, shell } \\
\text { fragments } \sim 3 \% \text {. Medium bed is poorly sorted, } \\
\text { pebbles and cobbles in a medium sand matrix, sand } \\
\text { QFL }=50 / 40 / 10 \text {, shell fragments } ~ 3 \% \text {, pebbles and } \\
\text { cobbles are intermediate in color. }\end{array}$ & I \\
\hline & & 4 & $0-30 \mathrm{~cm}$ & $\begin{array}{l}\text { interbedded fine-to-coarse and fine-to-medium sand, } \\
\text { sub-rounded, moderately to poorly sorted, medium } \\
\text { beds, orange grains present, QFL }=60 / 20 / 20 \text {, shell } \\
\text { fragments }=5-9 \%\end{array}$ & I \\
\hline & $4 \mathrm{~N}$ & 1 & $0-30 \mathrm{~cm}$ & $\begin{array}{l}\text { fine to medium sand, rounded - sub-rounded, } \\
\text { moderately sorted, } Q F L=80 / 10 / 10 \text {, shell fragments } \\
\sim 3 \%\end{array}$ & I \\
\hline & & 4 & $0-22 \mathrm{~cm}$ & $\begin{array}{l}\text { fine sand, well-sorted, sub-rounded, QFL }=80 / 15 / 5 \text {, } \\
\text { no shell fragments. }\end{array}$ & I \\
\hline & & & $\begin{array}{l}22-30 \\
\mathrm{~cm}\end{array}$ & $\begin{array}{l}\text { fine to medium sand, } \mathrm{QFL}=80 / 15 / 5 \text {, glassy orange } \\
\text { clasts, well-sorted, sub-rounded, no shell fragments. }\end{array}$ & \\
\hline $\begin{array}{l}\text { Winter } \\
2018\end{array}$ & $3 \mathrm{~S}$ & 1 & $0-30 \mathrm{~cm}$ & $\begin{array}{l}\text { medium sand, sub-angular, well-sorted, ripple marks, } \\
\text { QFL }=85 / 5 / 10 \text {, no shell fragments. }\end{array}$ & I \\
\hline & & 4 & $0-30 \mathrm{~cm}$ & $\begin{array}{l}\text { medium to very coarse sand, rounded to sub-angular, } \\
\text { well-sorted, } \sim 60 \% \text { quartz, } 11-20 \% \text { shell fragments. }\end{array}$ & I \\
\hline & $2 \mathrm{~S}$ & 1 & $0-30 \mathrm{~cm}$ & $\begin{array}{l}\text { Fine to medium sand, sub-rounded, well-sorted, QFL } \\
=80 / 10 / 10, \text { shell fragments } \sim 3 \%\end{array}$ & I \\
\hline & & 4 & $0-10 \mathrm{~cm}$ & $\begin{array}{l}0-10 \mathrm{~cm} \text { : fine sand, rounded - sub-rounded, } \\
\text { moderately sorted, QFL }=75 / 20 / 5 \text {, no shell } \\
\text { fragments }\end{array}$ & I \\
\hline & & & $\begin{array}{l}10-20 \\
\mathrm{~cm}\end{array}$ & $\begin{array}{l}\text { Fine sand, sub-rounded, moderately sorted, } \mathrm{QFL}= \\
30 / 30 / 40 \text {, no shell fragments. }\end{array}$ & \\
\hline & & & $\begin{array}{l}20-30 \\
\mathrm{~cm}\end{array}$ & $\begin{array}{l}\text { very fine sand, sub-rounded, well-sorted, } \mathrm{QFL}= \\
60 / 15 / 20 \text {, shell fragments } \sim 3 \%\end{array}$ & \\
\hline & $1 \mathrm{~S}$ & 1 & $0-30 \mathrm{~cm}$ & $\begin{array}{l}\text { fine to medium sand, sub-rounded to sub-angular, } \\
\text { well to moderately sorted, 80\% quartz, 5-9\% shell } \\
\text { fragments. }\end{array}$ & I \\
\hline & & 4 & $0-30 \mathrm{~cm}$ & $\begin{array}{l}\text { fine to coarse sand, sub-rounded to sub-angular, well } \\
\text { to moderately sorted, } \sim 90 \% \text { quartz, } \sim 3 \% \text { shell } \\
\text { fragments. }\end{array}$ & I \\
\hline & 0 & 1 & $0-30 \mathrm{~cm}$ & $\begin{array}{l}\text { very fine to fine sand, sub-rounded, well-sorted, QFL } \\
=80 / 10 / 10, \text { no shell fragments. }\end{array}$ & I \\
\hline & & 4 & $0-10 \mathrm{~cm}$ & $\begin{array}{l}\text { fine sand, sub-rounded to sub-angular, well-sorted, } \\
\text { thin laminations, } Q F L=45 / 45 / 10 \text {, no shell } \\
\text { fragments. }\end{array}$ & I \\
\hline & & & $\begin{array}{l}10-30 \\
\mathrm{~cm}\end{array}$ & $\begin{array}{l}\text { very fine sand, sub-angular, well-sorted, ripple } \\
\text { marks, flow shadows, QFL }=75 / 15 / 10 \text {, no shell } \\
\text { fragments. }\end{array}$ & \\
\hline & $1 \mathrm{~N}$ & 1 & $0-5 \mathrm{~cm}$ & $\begin{array}{l}\text { very fine sand, rounded - sub-rounded, well-sorted, } \\
\text { QFL = 30/30/40, no shells. }\end{array}$ & I \\
\hline
\end{tabular}




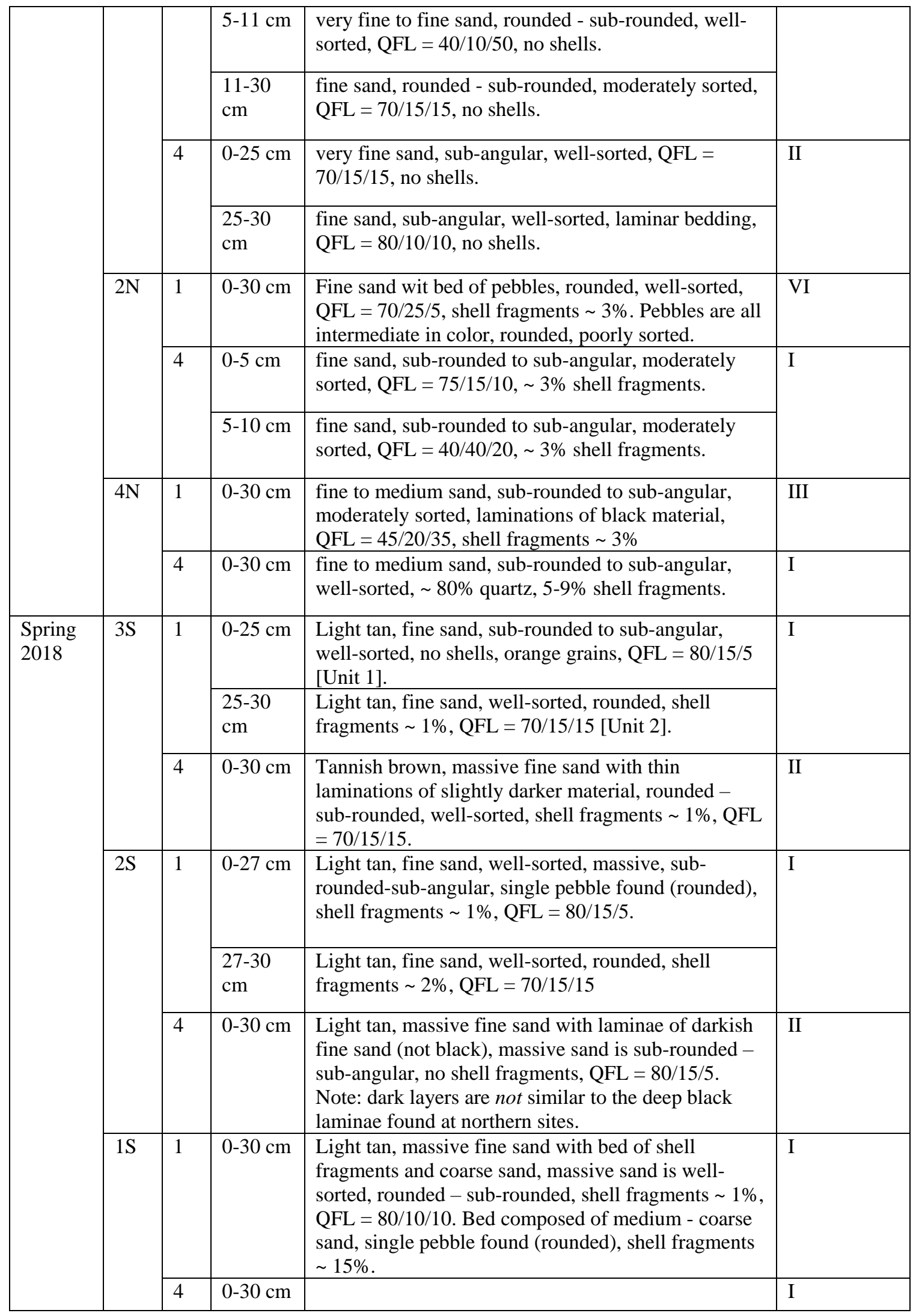




\begin{tabular}{|c|c|c|c|c|}
\hline & & & $\begin{array}{l}\text { Greyish tan, massive fine sand, rounded }- \text { sub- } \\
\text { rounded, well-sorted, shell fragments } \sim 5 \%, \mathrm{QFL}= \\
80 / 15 / 5 \text {. }\end{array}$ & \\
\hline \multirow[t]{8}{*}{0} & 1 & $0-10 \mathrm{~cm}$ & $\begin{array}{l}\text { Tannish brown color, fine sand, rounded, well-sorted, } \\
\text { no shells, QFL = 80/5/15 }\end{array}$ & \multirow[t]{4}{*}{ III } \\
\hline & & $\begin{array}{l}10-18 \\
\mathrm{~cm}\end{array}$ & $\begin{array}{l}\text { Tannish brown, fine sand, rounded, sorted, dark } \\
\text { laminations, no shells, } Q F L=65 / 10 / 25\end{array}$ & \\
\hline & & $\begin{array}{l}18-23 \\
\mathrm{~cm}\end{array}$ & $\begin{array}{l}\text { Tannish brown, fine sand, rounded, well-sorted, no } \\
\text { shells, QFL }=65 / 5 / 30\end{array}$ & \\
\hline & & $\begin{array}{l}23-27 \\
\mathrm{~cm}\end{array}$ & $\begin{array}{l}\text { Tannish brown, fine sand sub-rounded, well-sorted, } \\
\text { shell fragments } \sim 2 \%, \mathrm{QFL}=75 / 5 / 20\end{array}$ & \\
\hline & \multirow[t]{2}{*}{2} & $0-35 \mathrm{~cm}$ & $\begin{array}{l}\text { Blackish grey (very dark), some laminae of brownish } \\
\text { tan, fine sand, well-sorted, rounded - sub-rounded, } \\
\text { no shells, } Q F L=45 / 10 / 45\end{array}$ & \multirow[t]{2}{*}{$\mathrm{V}$} \\
\hline & & $\begin{array}{l}35-65 \\
\mathrm{~cm}\end{array}$ & $\begin{array}{l}\text { Tannish brown, thinly laminated, fine sand, well- } \\
\text { sorted, rounded, shell fragments } \sim 1 \%, \mathrm{QFL}=75 / 20 / 5\end{array}$ & \\
\hline & 3 & $0-30 \mathrm{~cm}$ & $\begin{array}{l}\text { Tannish brown, fine sand, greenish grains, rounded- } \\
\text { sub-rounded, well-sorted, shell fragments } \sim 3 \%, \mathrm{QFL} \\
=75 / 20 / 5\end{array}$ & I \\
\hline & 4 & $0-30 \mathrm{~cm}$ & $\begin{array}{l}\text { Tannish brown, fine sand, rounded-sub-rounded, } \\
\text { well-sorted, shell fragments } \sim 1 \%, \mathrm{QFL}=75 / 20 / 5\end{array}$ & I \\
\hline \multirow[t]{3}{*}{$1 \mathrm{~N}$} & 1 & $0-20 \mathrm{~cm}$ & $\begin{array}{l}\text { Light tan sand with interlaminated black material. } \\
\text { Laminae } ~ 2-3 \mathrm{~mm} \text {, black material more concentrated } \\
\text { at bottom of pit, matrix QFL }=80 / 15 / 5 \text { black material } \\
\text { similar to that found at } 2 \mathrm{~N} \text {. Well-sorted, rounded- } \\
\text { sub-rounded, no shells, fine grained. }\end{array}$ & \multirow[t]{2}{*}{ III } \\
\hline & & $\begin{array}{l}20-30 \\
\mathrm{~cm}\end{array}$ & $\begin{array}{l}\text { Light tan, fine grained sand, rounded- sub-rounded, } \\
\text { well-sorted, QFL }=60 / 30 / 10 \text {, shell fragments } \sim 2 \% \text {. }\end{array}$ & \\
\hline & 4 & $0-30 \mathrm{~cm}$ & $\begin{array}{l}\text { Light tan, fine sand, numerous orange, glassy grains, } \\
\text { thinly laminated with slightly darker grains. Well- } \\
\text { sorted, rounded - sub-rounded, QFL }=80 / 15 / 5 \text {, no } \\
\text { shells. }\end{array}$ & II \\
\hline \multirow[t]{3}{*}{$2 \mathrm{~N}$} & \multirow[t]{3}{*}{1} & $0-5 \mathrm{~cm}$ & $\begin{array}{l}\text { Gravels - pebbles in fine-to-coarse sand matrix, } \\
\text { larger clasts vary in color from dark to light, sand is } \\
\text { tannish brown. Poorly sorted, larger clasts rounded, } \\
\text { matrix rounded to sub-angular, shell fragments } \sim 3 \% \text {, } \\
\text { matrix QFL }=80 / 5 / 15 \text {, larger clasts exclusively } \\
\text { intermediate to mafic. }\end{array}$ & \multirow[t]{3}{*}{ IV \& VI } \\
\hline & & $5-25 \mathrm{~cm}$ & $\begin{array}{l}\text { Light brown, fine-to-medium sand, well-sorted, } \\
\text { rounded-sub-rounded, some greens and reds among } \\
\text { the grains, shell fragments } \sim 2 \% \text {, QFL }=60 / 20 / 20 \text {. }\end{array}$ & \\
\hline & & $\begin{array}{l}25-30 \\
\mathrm{~cm}\end{array}$ & $\begin{array}{l}\text { Trough cross-bedding, laminae } \sim 3 \mathrm{~mm} \text { thick, fine - } \\
\text { medium sand, well-sorted, rounded, shell fragments } \\
\sim 3 \%, \mathrm{QFL}=70 / 15 / 15 \text {. }\end{array}$ & \\
\hline
\end{tabular}




\begin{tabular}{|c|c|c|c|c|c|}
\hline & & 4 & $0-30 \mathrm{~cm}$ & $\begin{array}{l}\text { Greyish brown, laminated, rounded-sub-rounded, } \\
\text { well-sorted, coarse lithics, greens and reds among the } \\
\text { grains, shell fragments } \sim 7-10 \% \text {, red worms found, } \\
\text { several flies at surface, } \mathrm{QFL}=60 / 20 / 20 \text {. }\end{array}$ & II \\
\hline & \multirow[t]{2}{*}{$4 \mathrm{~N}$} & 1 & $0-30 \mathrm{~cm}$ & $\begin{array}{l}\text { Light tannish brown interbedded with laminae of } \\
\text { blackish grey, fine sand, rounded, well-sorted, shell } \\
\text { fragments } \sim 1 \%, \mathrm{QFL}=75 / 5 / 20 \text {, calcite(?) present. }\end{array}$ & II \\
\hline & & 4 & $0-20 \mathrm{~cm}$ & $\begin{array}{l}\text { Greyish } \tan \text {, fine sand, well-sorted, rounded, shell } \\
\text { fragments } \sim 7 \% \text {, red worms found, several flies at } \\
\text { surface, } Q F L=65 / 5 / 20 \text {. }\end{array}$ & I \\
\hline \multirow[t]{13}{*}{$\begin{array}{l}\text { Summer } \\
2018\end{array}$} & \multirow[t]{2}{*}{$3 S$} & 1 & $0-30 \mathrm{~cm}$ & $\begin{array}{l}\text { Massive, fine sand, lamination of darker brown fine } \\
\text { sand at } \sim 20 \mathrm{~cm} \text { from bottom, well-sorted, sub- } \\
\text { rounded, no shells, } Q F L=60 / 30 / 10 \text {. }\end{array}$ & II \\
\hline & & 4 & $0-30 \mathrm{~cm}$ & $\begin{array}{l}\text { Massive, fine sand interlaminated with medium sand. } \\
\text { Matrix: well-sorted, angular, no shells, QFL }= \\
\text { 80/10/10. Laminae: sorted, rounded, some rounded } \\
\text { gravels, shell fragments } \sim 3 \%, \mathrm{QFL}=70 / 20 / 10 \text {. }\end{array}$ & I \\
\hline & \multirow[t]{2}{*}{$2 \mathrm{~S}$} & 1 & $0-30 \mathrm{~cm}$ & $\begin{array}{l}\text { Massive, fine sand, faint interlaminae of darker fine } \\
\text { sand, matrix is well-sorted, rounded, no shells, QFL } \\
=70 / 15 / 15 \text {. Laminae are very faint and blend easily } \\
\text { into matrix when sampled, shell fragments } \sim 1 \%\end{array}$ & II \\
\hline & & 4 & $0-30 \mathrm{~cm}$ & $\begin{array}{l}\text { Massive, fine sand, well-sorted, rounded, shell } \\
\text { fragments }<1 \%, \mathrm{QFL}=70 / 15 / 15\end{array}$ & I \\
\hline & \multirow[t]{2}{*}{$1 \mathrm{~S}$} & 1 & $0-30 \mathrm{~cm}$ & $\begin{array}{l}\text { Fine sand with thin laminae of gravel and pebbles } \\
\text { throughout, poorly sorted, rounded (all clast sizes), } \\
\text { some large shell fragments }(>5 \mathrm{~cm}) \text {, shell fragments } \\
<1 \% \text {, QFL }=80 / 15 / 5 \text {. }\end{array}$ & VI \\
\hline & & 4 & $0-30 \mathrm{~cm}$ & $\begin{array}{l}\text { Massive, fine sand with buried kelp at } \sim 10 \mathrm{~cm} \text { from } \\
\text { bottom (kelp was covering most of beach during } \\
\text { sampling), well-sorted, rounded, no shells, } Q F L= \\
80 / 10 / 10 \text {. }\end{array}$ & I \\
\hline & \multirow[t]{2}{*}{0} & 1 & $0-30 \mathrm{~cm}$ & $\begin{array}{l}\text { Massive, fine sand, well-sorted, rounded, no shells, } \\
\text { no 'dredge' material present, QFL }=80 / 5 / 15 \text {. }\end{array}$ & I \\
\hline & & 4 & $0-20 \mathrm{~cm}$ & $\begin{array}{l}\text { Massive, fine sand, well-sorted, rounded, no } \\
\text { 'dredge', shell fragments }<1 \% \text {, red worms found, } \\
\text { QFL }=80 / 5 / 15 \text {. }\end{array}$ & I \\
\hline & \multirow[t]{2}{*}{$1 \mathrm{~N}$} & 1 & $0-30 \mathrm{~cm}$ & $\begin{array}{l}\text { Greyish tan, massive, fine sand, well-sorted, rounded, } \\
\text { no shells, } \mathrm{QFL}=80 / 15 / 5\end{array}$ & I \\
\hline & & 4 & $0-15 \mathrm{~cm}$ & $\begin{array}{l}\text { Massive, fine sand, sub-rounded, shell fragments } \\
\sim 2 \%, \mathrm{QFL}=80 / 5 / 15 \text {. }\end{array}$ & I \\
\hline & \multirow[t]{2}{*}{$2 \mathrm{~N}$} & 1 & $0-30 \mathrm{~cm}$ & $\begin{array}{l}\text { Massive, fine sand interlaminated with darker fine } \\
\text { sand (very similar to Pit } 1 \text { at } 4 \mathrm{~N} \text { ), well-sorted, } \\
\text { rounded, thin bed with twigs and pockets of air found } \\
\text { at } \sim 20 \mathrm{~cm} \text { from bottom, scarce shell fragments @ < } \\
1 \%, \mathrm{QFL}=80 / 10 / 10\end{array}$ & II \\
\hline & & 4 & $0-10 \mathrm{~cm}$ & $\begin{array}{l}\text { Massive, medium sand with a bed of fine sand. } \\
\text { medium sand is well-sorted, sub-angular }- \text { sub- } \\
\text { rounded, shell fragments } \sim 5 \% \text {, QFL }=60 / 15 / 25 \text {. } \\
\text { Fine sand is in } \sim 3 \mathrm{~cm} \text { bed, well-sorted, rounded, } \\
\text { shell fragments } \sim 3 \%, Q F L=80 / 10 / 10 \text {. }\end{array}$ & I \\
\hline & $4 \mathrm{~N}$ & 1 & $0-30 \mathrm{~cm}$ & & II \\
\hline
\end{tabular}




\begin{tabular}{|l|l|l|l|l|}
\hline & & & $\begin{array}{l}\text { Tannish grey sand with thin laminae of dark grey } \\
\text { material, massive, fine sand, well-sorted, rounded - } \\
\text { sub-rounded, no shells, QFL = 80/5/15. }\end{array}$ & \\
\cline { 2 - 6 } & 4 & $0-15 \mathrm{~cm}$ & $\begin{array}{l}\text { Tannish grey, massive, fine sand, well-sorted, } \\
\text { rounded - sub-rounded, shell fragments } ~ 3 \%, \mathrm{QFL}= \\
60 / 15 / 25 .\end{array}$ & $\mathrm{I}$ \\
\hline
\end{tabular}


APPENDIX D: GRAINSIZE DATA BY SITE 

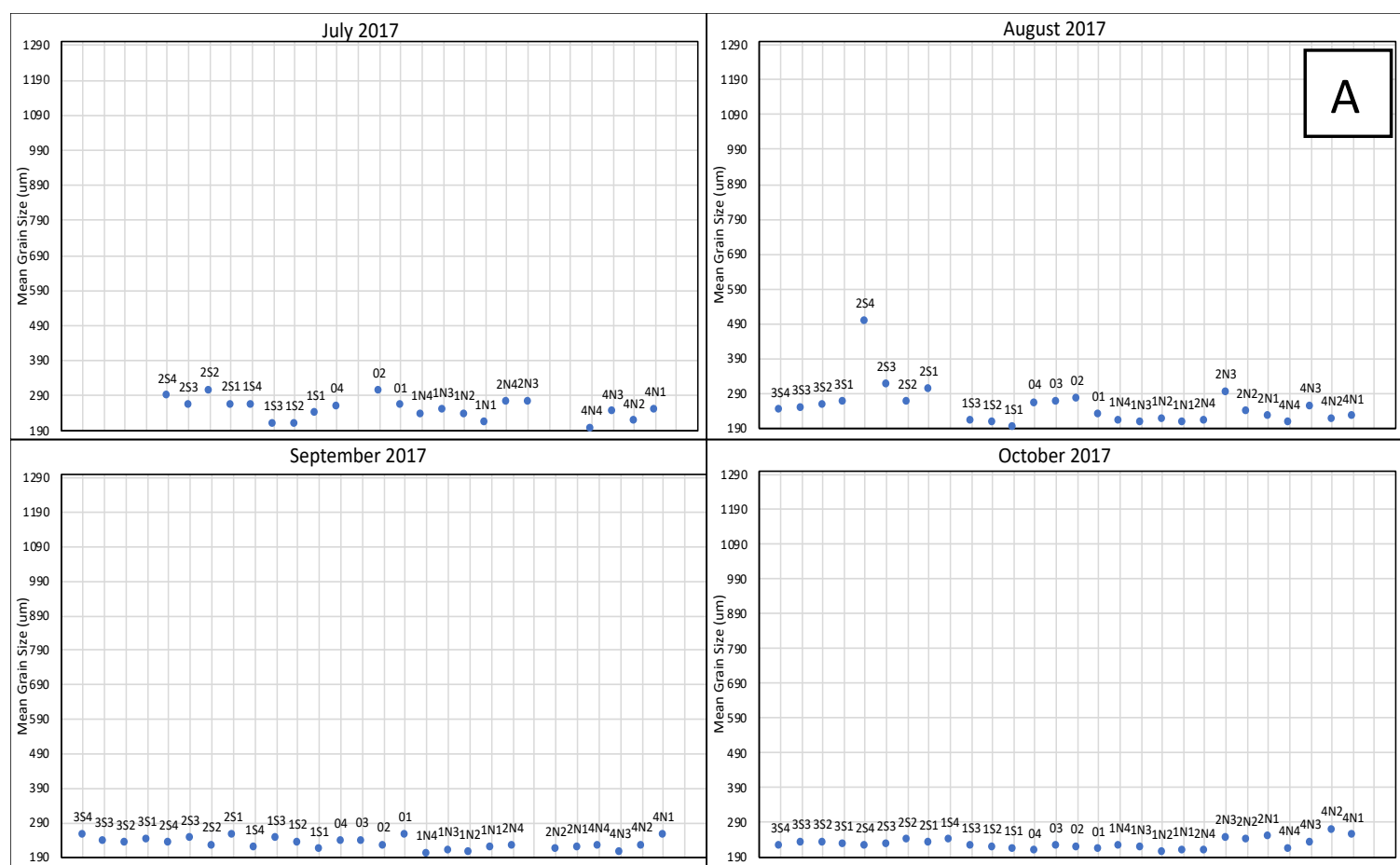

Figure D1a: Spatial distribution of median grainsize, July - October 2017.

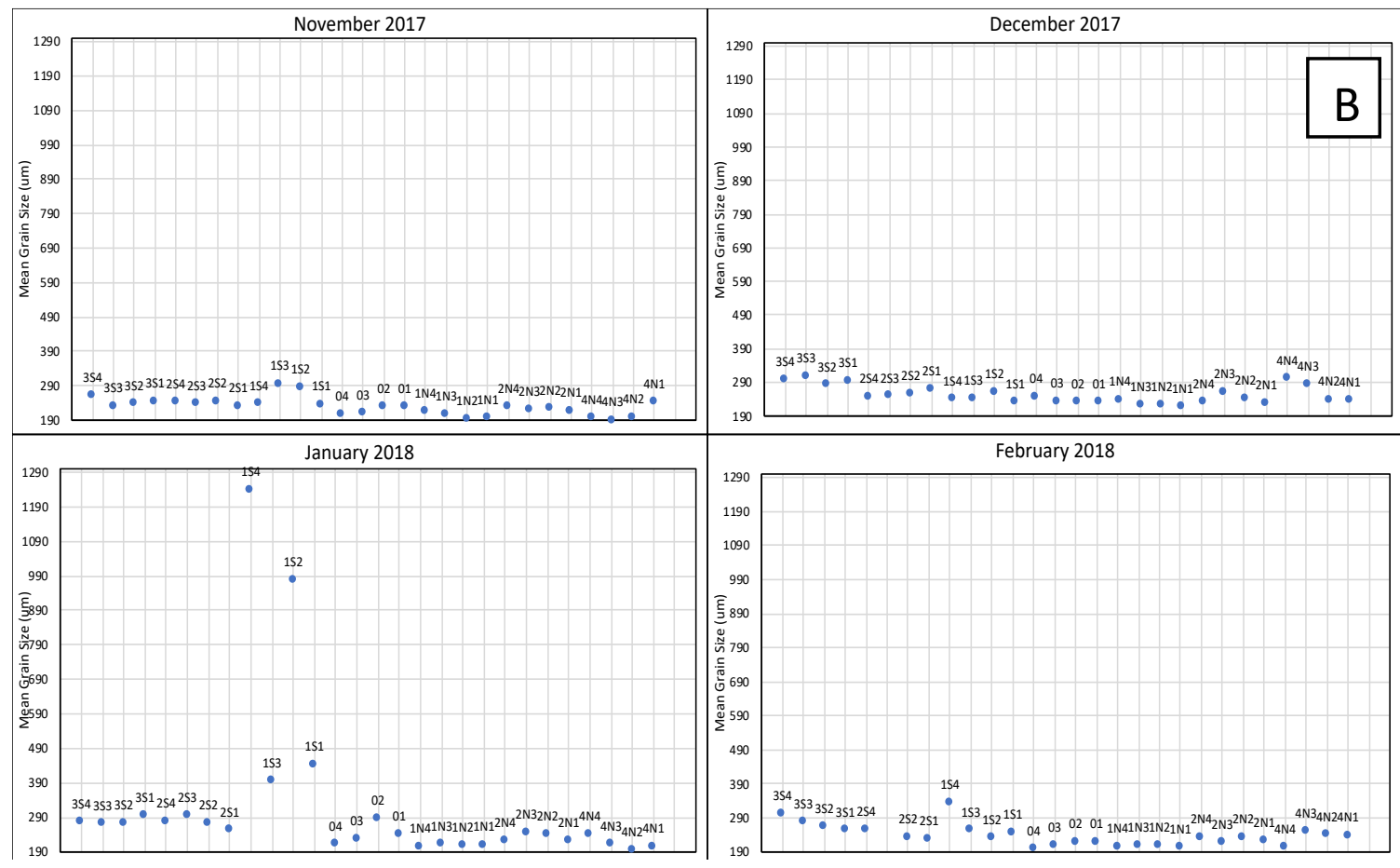

Figure D1b: Spatial distribution of median grainsize, November 2017 - February 2019. 

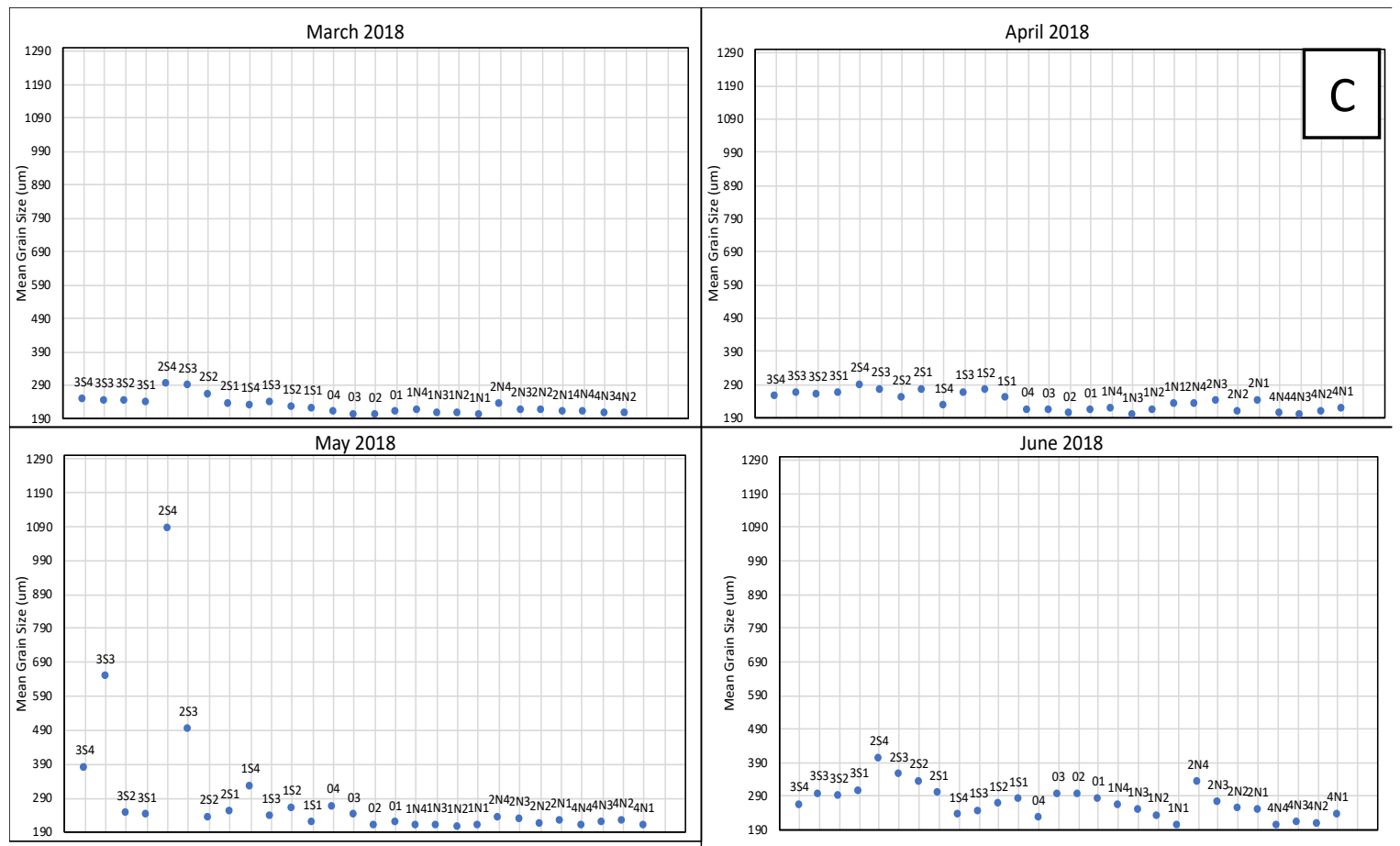

Figure D1c: Spatial distribution of median grainsize, March - June 2018.

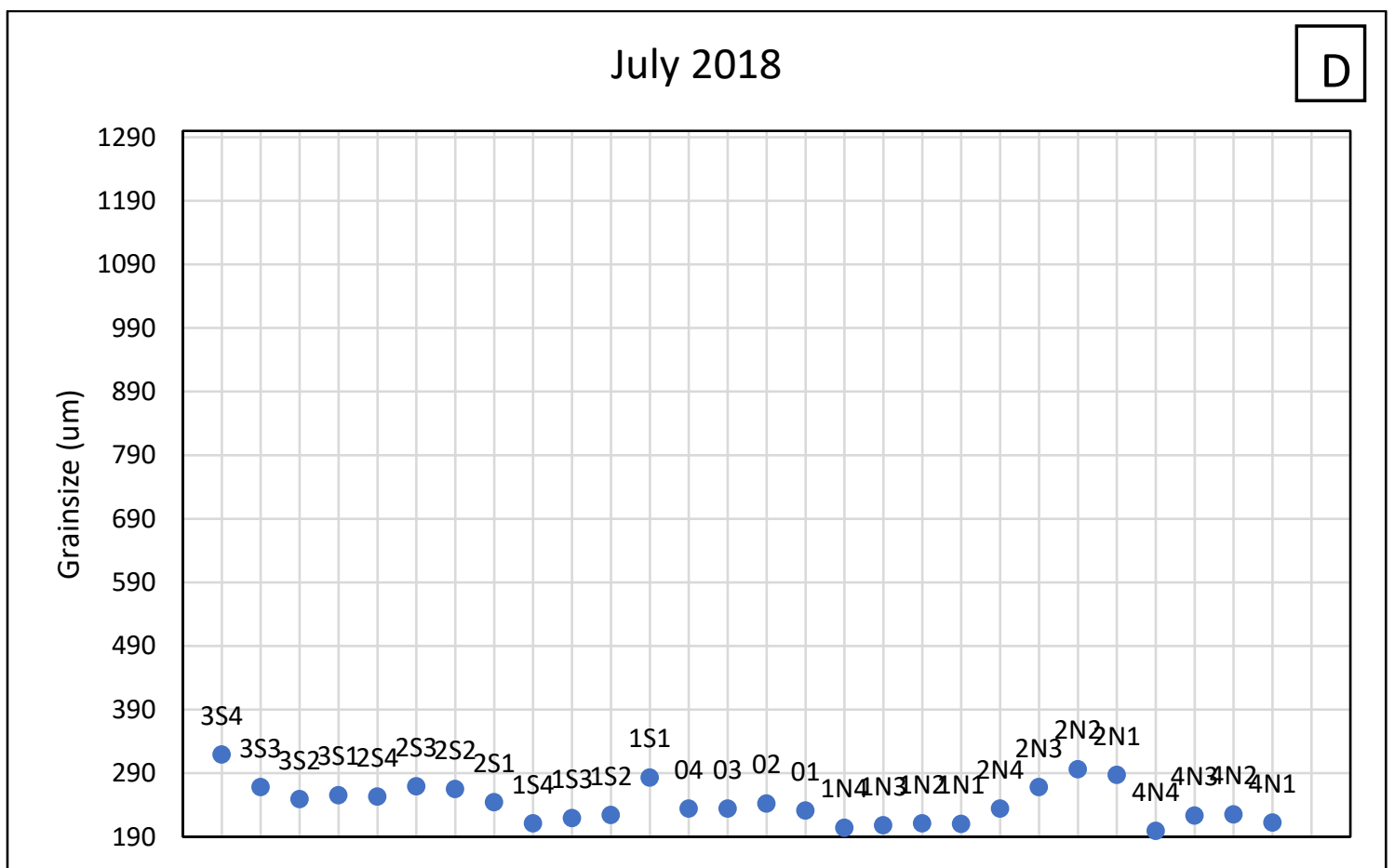

Figure D2: Spatial distribution of median grainsize by month. The y-axes show grainsize in microns; the $\mathrm{x}$ axes show transect locations by site. All four divisions of each transect are shown. It is apparent that the temporal-spatial coarsening trend observed in the overall average median grainsize data (Figs. 8-12) was influenced by local spikes in median grainsize at Site $1 \mathrm{~S}$ in January 2018 and Sites 2S and 3S in May 2018. The largest grainsize observed during each of these months occurred at the transect division closest to the ocean (e.g., 1S-4). There were no apparent trends along individual transects. 
APPENDIX E: BIRD AND INVERTEBRATE SPECIES LISTS 


\begin{tabular}{|c|c|c|}
\hline \multicolumn{2}{|l|}{ Birds } & \multirow{2}{*}{$\begin{array}{l}\text { Invertebrates } \\
\text { Americhelidium sp. }\end{array}$} \\
\hline American crow & Thayer's gull & \\
\hline Black-crowned night heron & Turkey vulture & Archaeomysis grebnitzki \\
\hline Barn swallow & Western grebe & Bledius sp. \\
\hline Black oystercatcher & Western gull & Emerita analoga \\
\hline Black phoebe & Western sandpiper & Eohaustorius sp. \\
\hline Black turnstone & Whimbrel & Excirolana chiltoni \\
\hline Black-bellied plover & Willet & Excirolana linguifrons \\
\hline Brant & & Magelona pitelkai \\
\hline Brown pelican & & Megalorchestia sp. \\
\hline Brown-headed cowbird & & Thinopinus pictus \\
\hline Bufflehead & & Thoracophelia dillonensis \\
\hline CA gull & & Thoracophelia mucronata \\
\hline Caspian tern & & Thoracophelia williamsi \\
\hline Common grackle & & Unidentified arthropod \\
\hline Common Loon & & Unidentified gastropod (a snail) \\
\hline Double-crested cormorant & & Nematoda \\
\hline European starling & & Unidentified copepod \\
\hline Great blue heron & & Hemipteran (looks like aphids) \\
\hline Great egret & & Cercyonsp. \\
\hline Heermann's gull & & Unidentified (poss. Glyceridae) \\
\hline Hooded merganser & & \\
\hline House sparrow & & \\
\hline Kildeer & & \\
\hline Least Sandpiper & & \\
\hline Long-billed curlew & & \\
\hline Mallard & & \\
\hline Marbled godwit & & \\
\hline Osprey & & \\
\hline Red-tailed hawk & & \\
\hline Ring-billed gull & & \\
\hline Royal tern & & \\
\hline Sanderling & & \\
\hline Say's Phoebe & & \\
\hline Snowy egret & & \\
\hline Snowy plover & & \\
\hline Spotted sandpiper & & \\
\hline Surf scoter & & \\
\hline
\end{tabular}


APPENDIX F: GRAINSIZE VS. SORTING 

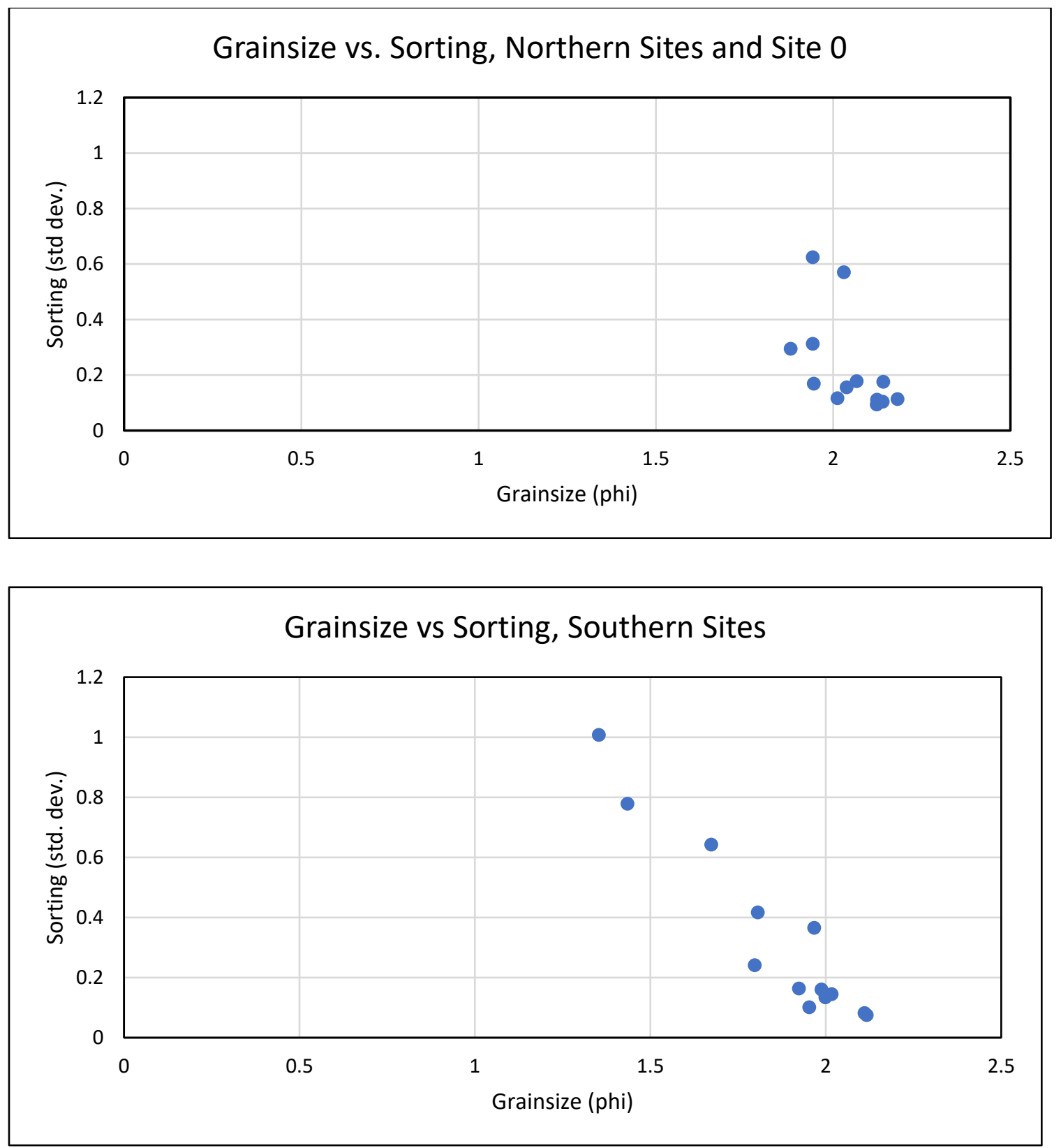

Figure F1: Mean median grainsize versus sorting for the northern Sites and Site 0 (a) and the southern Sites (b). Grainsize is shown in phi; sorting is shown as standard deviation. The southern Sites show a strong trend of better sorting with smaller grainsize. This trend is not as strong among the northern Sites and Site 0 . 
APPENDIX G: SURFACE SAMPLE MUNSELL COLORS 


\begin{tabular}{|c|c|c|c|c|c|}
\hline & Jul-17 & Aug-17 & Sep-17 & Oct-17 & Nov-17 \\
\hline Site & Color & Color & Color & Color & Color \\
\hline 354 & no data & 10YR 5/3 & 10YR $6 / 3$ & 10YR $6 / 3$ & 10YR $7 / 2$ \\
\hline $3 S 3$ & no data & 10YR $6 / 3$ & 10YR $6 / 3$ & 10YR $6 / 3$ & $2.5 Y 6 / 2$ \\
\hline $3 S 2$ & no data & 10YR 6/3 & 10YR $6 / 3$ & no data & 10YR $7 / 2$ \\
\hline $3 S 1$ & no data & 1OYR $6 / 3$ & 10YR $7 / 3$ & 10YR 6/3 & $2.5 Y 6 / 2$ \\
\hline $2 S 4$ & 10YR 5/3 & 10YR 6/3 & 10YR $6 / 3$ & no data & 10YR 7/2 \\
\hline $2 S 3$ & 10YR 6/2 & 10YR 5/3 & 10YR $7 / 3$ & no data & 10YR 6/2 \\
\hline $2 S 2$ & 10 YR 5/3 & 10YR $6 / 3$ & 10YR 7/2 & 10YR 7/2 & 10YR $7 / 2$ \\
\hline $2 S 1$ & 10YR 6/2 & 10YR 5/3 & 10YR $5 / 3$ & no data & $2.5 Y 6 / 2$ \\
\hline $1 S 4$ & 10YR 6/2 & 10YR 6/3 & $2.5 Y 6 / 2$ & 10YR 7/2 & 10YR $7 / 2$ \\
\hline 153 & 10YR 6/2 & 10YR $6 / 3$ & 10YR 5/3 & no data & $2.5 Y R 6 / 2$ \\
\hline $1 S 2$ & 10YR 6/2 & 10YR $6 / 3$ & 10YR $6 / 3$ & no data & 10 YR $6 / 2$ \\
\hline $1 S 1$ & 10YR 6/2 & 10YR $7 / 3$ & 10YR 6/3 & 10YR $6 / 3$ & 10YR $7 / 3$ \\
\hline 04 & 10YR 5/2 & 10YR 5/3 & 10YR 6/3 & no data & 10YR 6/2 \\
\hline 03 & 10YR $5 / 3$ & no data & 10YR 5/3 & 10YR 6/3 & $2.5 Y 7 / 2$ \\
\hline 02 & 10YR 6/2 & 10YR $6 / 3$ & 10YR 5/3 & 10YR 6/3 & 10YR 6/2 \\
\hline 01 & 10 YR 5/3 & 10YR 6/2 & 10 YR $5 / 2$ & no data & 10YR 6/2 \\
\hline 1N4 & 10 YR 5/3 & 10YR 6/2 & 10YR $5 / 3$ & no data & 10YR $7 / 2$ \\
\hline 1N3 & 10YR 5/2 & 10YR $6 / 3$ & $2.5 Y 8 / 2$ & 10YR $6 / 3$ & 10YR 6/2 \\
\hline 1N2 & 10YR $5 / 3$ & 10YR $6 / 3$ & 10YR 6/2 & 10YR 6/2 & 10YR $7 / 2$ \\
\hline 1N1 & 10YR $6 / 3$ & 10YR 6/3 & 10YR 6/3 & 10YR 6/2 & 10YR $6 / 2$ \\
\hline 2N4 & 10YR 5/3 & 10YR $6 / 3$ & 10YR $7 / 2$ & 10YR $6 / 3$ & 10YR 6/2 \\
\hline 2N3 & 10 YR 5/2 & 10YR 6/3 & 10YR $5 / 3$ & 10YR $5 / 3$ & 10YR 6/2 \\
\hline $2 \mathrm{~N} 2$ & 10YR 4/2 & 10YR 6/3 & 10YR 5/3 & no data & 10YR 6/2 \\
\hline 2N1 & 10YR 5/2 & 10YR $6 / 3$ & 10YR 6/2 & 10YR 5/2 & 10YR $7 / 2$ \\
\hline 4N4 & 10YR 5/3 & 10YR 5/2 & 10YR 6/2 & no data & 10YR $7 / 2$ \\
\hline 4N3 & 10 YR 5/3 & 10YR 5/3 & $2.5 Y 7 / 2$ & 10YR 5/2 & 10YR $7 / 2$ \\
\hline $4 N 2$ & 10YR 6/2 & 10YR 6/2 & 10YR 5/2 & no data & 10YR $6 / 2$ \\
\hline 4N1 & 10 YR 5/2 & 10 YR 5/2 & $2.5 Y 7 / 2$ & 10YR 5/1 & 10YR $7 / 2$ \\
\hline
\end{tabular}




\begin{tabular}{|c|c|c|c|c|}
\hline & Dec-17 & Jan-18 & Feb-18 & Mar-18 \\
\hline 354 & 10YR $5 / 3$ & 10YR 5/3 & 10YR 5/3 & 10YR $5 / 3$ \\
\hline $3 S 3$ & 10YR 5/4 & 10YR $5 / 3$ & 10YR 5/3 & 10YR $6 / 3$ \\
\hline $3 S 2$ & 10YR $4 / 3$ & 10YR 5/3 & 10YR 5/3 & 10YR $6 / 3$ \\
\hline $3 S 1$ & 10YR 5/3 & 10YR 6/2 & 10YR 5/2 & 10YR $6 / 2$ \\
\hline $2 S 4$ & 10YR $5 / 3$ & 10YR $5 / 3$ & 10YR 5/3 & 10YR $5 / 3$ \\
\hline $2 S 3$ & 10YR 5/2 & 10YR 5/3 & 10YR 5/3 & 10YR $5 / 3$ \\
\hline $2 S 2$ & 10YR $5 / 3$ & 10YR 5/3 & 10YR 5/3 & 10YR $5 / 3$ \\
\hline 2S1 & 10YR 5/2 & 10YR 5/2 & 10YR 5/3 & 10YR $5 / 3$ \\
\hline $1 S 4$ & 10YR $5 / 3$ & 10YR $5 / 3$ & 10YR 5/3 & 10YR $5 / 3$ \\
\hline 153 & 10YR $5 / 3$ & 10YR $5 / 3$ & 10YR $5 / 3$ & 10YR $5 / 2$ \\
\hline $1 S 2$ & 10YR $6 / 3$ & 10YR 6/3 & 10YR 6/3 & 10YR $5 / 3$ \\
\hline 1S1 & 10YR 6/3 & 10YR 6/3 & 10YR 6/3 & 10YR $6 / 3$ \\
\hline 04 & 10YR $6 / 3$ & 10YR $5 / 2$ & 10YR 5/3 & 10YR $5 / 3$ \\
\hline 03 & 10YR 5/3 & 10YR $5 / 2$ & 10YR 5/2 & 10YR $5 / 2$ \\
\hline 02 & 10YR $5 / 3$ & 10YR 5/2 & 10YR 5/3 & 10YR $5 / 2$ \\
\hline 01 & 10YR 5/3 & 10YR 5/2 & 10YR 5/3 & 10YR 5/3 \\
\hline 1N4 & 10YR 5/3 & 10YR 5/2 & 10YR 5/2 & 10YR $5 / 3$ \\
\hline 1N3 & 10YR 5/3 & 10YR 5/2 & 10YR 6/3 & 10YR $5 / 2$ \\
\hline 1N2 & 10YR 5/2 & 10YR 5/2 & 10YR 5/2 & 10YR $5 / 2$ \\
\hline 1N1 & 10YR 5/3 & 10YR 5/2 & 10YR 6/3 & 10YR 5/2 \\
\hline 2N4 & 10YR $6 / 3$ & 10YR $5 / 3$ & 10YR 5/3 & 10YR $5 / 2$ \\
\hline 2N3 & 10YR 5/2 & 10YR 5/2 & 10YR 5/3 & 10YR $5 / 2$ \\
\hline $2 \mathrm{~N} 2$ & 10YR 5/3 & 10YR 5/2 & 10YR 5/3 & 10YR $5 / 2$ \\
\hline 2N1 & 10YR 5/2 & 10YR 5/2 & 10YR 6/3 & 10YR $6 / 3$ \\
\hline 4N4 & 10YR 6/3 & 10YR 5/2 & 10YR 6/2 & 10YR 5/2 \\
\hline 4N3 & 10YR 5/2 & 10YR 5/2 & 10YR 5/3 & 10YR $5 / 2$ \\
\hline 4N2 & 10YR 5/2 & 10YR 5/2 & 10YR 5/2 & 10YR $5 / 2$ \\
\hline 4N1 & 10YR 5/3 & 10YR 5/2 & 10YR 6/2 & no data \\
\hline
\end{tabular}


354

353

352

351

2S4

$2 S 3$

252

2S1

1S4

153

$1 S 2$

151

04

03

02

01

1N4

1N3

1N2

1N1

2N4

2N3

2N2

2N1

4N4

4N3

4N2

4N1

\begin{tabular}{|c|c|c|c|}
\hline Apr-18 & May-18 & Jun-18 & Jul-18 \\
\hline 10YR 6/2 & 10YR $6 / 2$ & 10YR $7 / 2$ & 10YR $6 / 2$ \\
\hline 10YR 7/2 & 10YR $6 / 2$ & 10YR 6/2 & 10YR $6 / 2$ \\
\hline 10YR 6/2 & 10YR $6 / 2$ & 10YR $7 / 2$ & 10YR $6 / 2$ \\
\hline 10YR 6/2 & 10YR $6 / 2$ & 10YR 6/2 & 10YR $6 / 2$ \\
\hline 10YR 6/2 & 10YR $6 / 2$ & 10YR 6/2 & 10YR $6 / 2$ \\
\hline 10YR 7/2 & 10YR $6 / 2$ & 10YR 6/2 & 10YR $6 / 2$ \\
\hline 10YR 7/2 & 10YR 6/2 & 10YR 6/2 & 10YR $6 / 2$ \\
\hline 10YR 6/2 & 10YR 7/2 & 10YR 6/2 & 10YR 6/2 \\
\hline 10YR 7/2 & 10YR 6/2 & 10YR 6/2 & 10YR $7 / 2$ \\
\hline 10YR 6/2 & 10YR $7 / 2$ & 10YR 6/2 & 10YR $7 / 2$ \\
\hline 10YR 7/2 & 10YR $7 / 2$ & 10YR 6/2 & 10YR $6 / 2$ \\
\hline 10YR 7/2 & 10YR $7 / 2$ & 10YR 6/2 & 10YR 6/2 \\
\hline 10YR 7/2 & 10YR 6/2 & 10YR 6/2 & 10YR $6 / 2$ \\
\hline 10YR $7 / 2$ & 10YR 7/2 & 10YR 6/2 & 10YR $6 / 2$ \\
\hline 10YR 7/2 & 10YR $7 / 2$ & 10YR 6/2 & 10YR 6/2 \\
\hline 10YR 6/2 & 10YR $7 / 2$ & 10YR 6/2 & 10YR 6/2 \\
\hline 10YR 7/2 & 10YR $7 / 2$ & 10YR 7/2 & 10YR 6/2 \\
\hline 10YR 6/2 & 10YR 6/2 & 10YR 6/2 & 10YR 6/2 \\
\hline 10YR 6/2 & 10YR 7/2 & 10YR 6/2 & 10YR $6 / 2$ \\
\hline 10YR $7 / 2$ & 10YR $6 / 2$ & 10YR 6/2 & 10YR $6 / 2$ \\
\hline 10YR 6/2 & 10YR $6 / 2$ & 10YR 6/2 & 10YR $6 / 2$ \\
\hline 10YR 6/2 & 10YR 7/2 & 10YR 6/2 & 10YR 6/2 \\
\hline 10YR 7/2 & 10YR $7 / 2$ & 10YR 6/2 & 10YR $6 / 2$ \\
\hline 10YR 6/2 & 10YR 7/2 & 10YR 6/2 & 10YR $6 / 2$ \\
\hline 10YR 6/2 & 10YR 6/2 & 10YR 6/2 & 10YR $6 / 2$ \\
\hline 10YR 6/2 & 10YR $7 / 2$ & 10YR 6/2 & 10YR 6/2 \\
\hline 10YR 6/2 & 10YR 6/2 & 10YR 6/2 & 10YR $6 / 2$ \\
\hline 10YR 7/2 & 10YR 6/2 & 10YR 7/2 & 10YR 6/2 \\
\hline
\end{tabular}

